UNIVERSIDADE DE SÃO PAULO

FACULDADE DE ODONTOLOGIA

\title{
DESLOCAMENTOS CONDILARES ENTRE RC E MIC, COM E SEM DESPROGRAMAÇÃO, EM INDIVÍDUOS ASSINTOMÁTICOS, COM MALOCLUSÃO DE CI II
}

SOLANGE MONGELLI DE FANTINI

Tese apresentada à Faculdade de Odontologia da Universidade de São Paulo, para concorrer ao Título de Doutora, pelo Curso de Pós-Graduação em Odontologia. Área de Concentração em Ortodontia Orientador: Prof. Dr. Jorge Abrão

São Paulo 
UNIVERSIDADE DE SÃO PAULO

FACULDADE DE ODONTOLOGIA

\section{DESLOCAMENTOS CONDILARES ENTRE RC E MIC, COM E SEM DESPROGRAMAÇÃO, EM INDIVÍDUOS ASSINTOMÁTICOS, COM MALOCLUSÃO DE CI II}

SOLANGE MONGELLI DE FANTINI

Tese apresentada à Faculdade de Odontologia da Universidade de São Paulo, para concorrer ao Título de Doutora, pelo Curso de Pós-Graduação em Odontologia. Área de Concentração em Ortodontia

São Paulo 
Data da Defesa:

1

Banca Examinadora

Prof. Dr.

Julgamento:

Assinatura:

Prof. Dr.

Julgamento:

Assinatura:

Prof. Dr.

Julgamento:

Assinatura:

Prof. Dr.

Julgamento:

Assinatura:

Prof. Dr.

Julgamento:

Assinatura: 
Ao meu pai, Dr. Luciano Fantini, ofereço carinhosamente, este trabalho. 
Ao Prof. Dr. JORGE ABRÃO, responsável pela orientação deste trabalho, meu profundo reconhecimento. 


\section{AGRADECIMENTOS}

Ao Prof. Dr. Júlio Wilson Vigorito, que me tem propiciado amplas oportunidades de trabalho e pesquisa, no Departamento de Ortodontia e Odontopediatria da Faculdade de Odontologia da USP.

Ao Prof. Dr. Sebastião Interlandi, pelas lúcidas contribuições no decorrer desta investigação.

Ao Prof. Dr. Silas da Cunha Ribeiro, pelas oportunas apreciações sobre este estudo.

Aos colegas do Departamento de Ortodontia e Odontopediatria, Mestres João Batista de Paiva, José Rino Neto, Gladys Cristina Domingues e André Tortamano, cujos trabalhos são constantes incentivos às atividades por nós aqui desenvolvidas.

Aos alunos das $13^{\mathrm{a}}$ e $14^{\mathrm{a}}$ turmas do Curso de Mestrado na área de Ortodontia, cujas participações clínicas foram de importância especial na elaboração deste trabalho.

Aos estagiários Lylian Kazumi Kanashiro, Patrícia Helena Pereira Almeida, Ana Angélica Bezerra Santana, Milton Missaka e Fábio Nauff, pelas colaborações diversas, durante o desenvolvimento deste trabalho. 
Aos funcionários do Departamento de Ortodontia e Odontopediatria da FOUSP, sempre atentos às inúmeras solicitações.

Às Bibliotecárias Luzia Marilda Zoppei Murgia e Moraes e Maria Aparecida Pinto, pelas valiosas colaborações.

À participação de Sandra Regina Malagutti, que orientou eficientemente, a análise estatística.

Aos pacientes participantes deste estudo, minha permanente gratidão. 


\section{SUMÁRIO}

p.

RESUMO

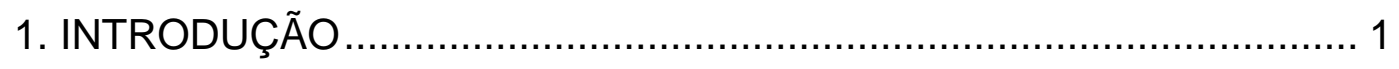

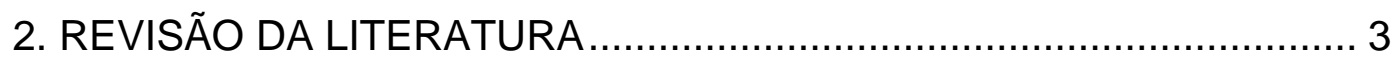

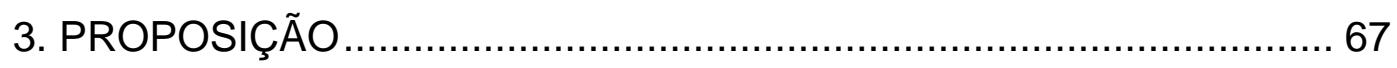

4. CASUÍSTICA - MATERIAL E MÉTODOS ....................................69 69

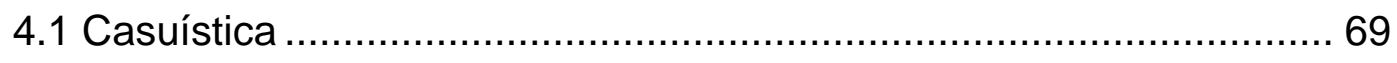

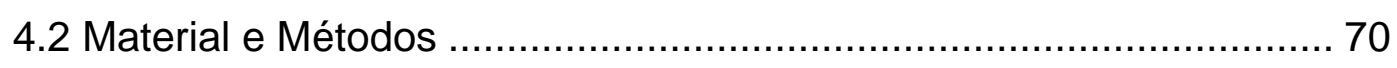

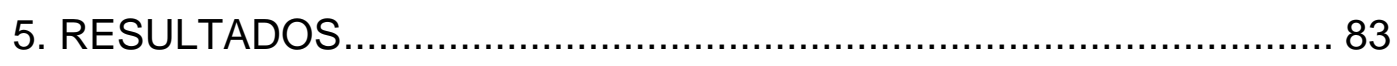

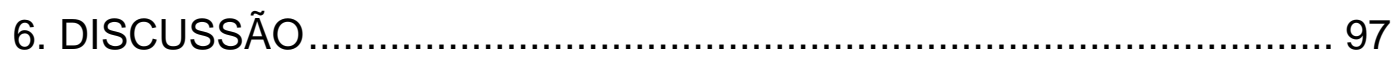

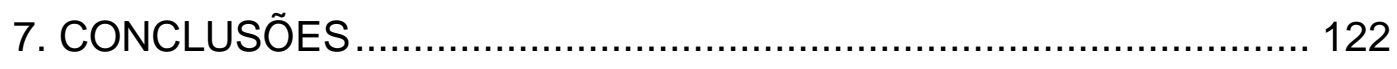

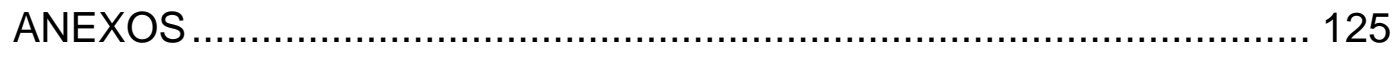

REFERÊNCIAS BIBLIOGRÁFICAS ...................................... 132

SUMMARY

APÊNDICE 


\section{LISTA DE GRÁFICOS E FIGURAS}

Gráfico 1 - Correlação entre idade cronológica ao início do uso da placa e medida de deslocamento condilar, no sentido vertical, do lado direito .93

Gráfico 2 - Correlação entre idade cronológica ao final do uso da placa e medida de deslocamento condilar, no sentido vertical, do lado direito 93

Gráfico 3 - Correlação entre maturidade esquelética ao início do uso da placa e medida de deslocamento condilar, no sentido vertical, do lado direito94 Gráfico 4 - Correlação entre maturidade esquelética ao final do uso da placa e medida de deslocamento condilar, no sentido vertical, do lado direito ....94

Gráfico 5 - Correlação entre idade cronológica ao início do uso da placa e medida de deslocamento condilar no sentido vertical, do lado esquerdo .....95

Gráfico 6 - Correlação entre idade cronológica ao final do uso da placa e medida de deslocamento condilar no sentido vertical, do lado esquerdo .....95 Gráfico 7 - Correlação entre maturidade esquelética ao início do uso da placa e medida de deslocamento condilar, no sentido vertical, do lado esquerdo 96 
Gráfico 8 - Correlação entre maturidade esquelética ao final do uso da placa e medida de deslocamento condilar, no sentido vertical, do lado

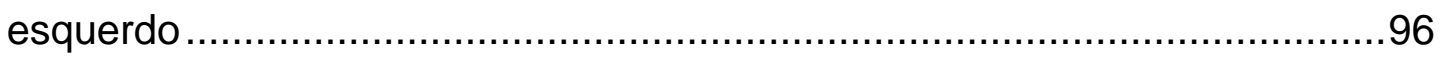

Figura 1 - Demarcação de RC no Indicador de Posição Condilar.................78

Figura 2 - Demarcação de MIC no Indicador de Posição Condilar ................79

Figura 3 - Demarcação das posições condilares no gráfico do IPC, no plano

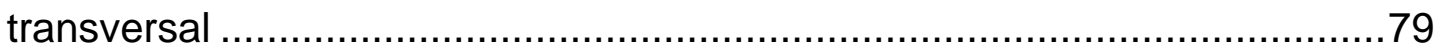

Figura 4 - Gráficos do IPC dos lados direito, esquerdo, e transversal ..........80

Figura 5 - Modelos de paciente do grupo Experimental, montados em articulador, relacionados em MIC e em RC

Figura 6 - Modelos de paciente do grupo Controle, montados em articulador, relacionados em MIC e em $\mathrm{RC}$ 116

Figura 7 - Aspectos faciais de paciente do grupo Experimental, antes (MIC) e após (RC) desprogramação neuromuscular com placa .118

Figura 8 - Aspecto intra-bucal de paciente do grupo Experimental, antes (MIC) e após (RC) desprogramação neuromuscular com placa 119 


\section{LISTA DE TABELAS}

TABELA 5.1 - Comparação entre os grupos Experimental e Controle, em relação aos deslocamentos condilares avaliados .85

TABELA 5.2 - Comparação entre os grupos Experimental e Controle, em relação às variáveis "idade cronológica" e "maturidade esquelética" .86

TABELA 5.3 - Comparação entre homens e mulheres do grupo Experimental, em relação aos deslocamentos condilares avaliados .86

TABELA 5.4 - Comparação entre homens e mulheres do grupo Controle, em relação aos deslocamentos condilares avaliados

TABELA 5.5 - Comparação entre os dados dos lados direito e esquerdo do grupo Experimental, relativos aos deslocamentos condilares avaliados 87

TABELA 5.6 - Comparação entre os dados dos lados direito e esquerdo do grupo Controle, em relação aos deslocamentos condilares avaliados .88

TABELA 5.7 - Teste de correlação entre as medidas de idade cronológica e de maturidade esquelética e as medidas de deslocamento condilar do grupo Experimental .88 
TABELA 5.8 - Teste de correlação entre tempo de uso da placa desprogramadora e as medidas de deslocamento condilar do grupo Experimental .89

TABELA 5.9 - Comparação entre pacientes dentro e fora do período de crescimento acelerado, do grupo Experimental, em relação aos deslocamentos condilares avaliados .90

TABELA 5.10 - Comparação entre os valores corrigidos do grupo Experimental e os dados originais do grupo Controle, relativos aos deslocamentos condilares avaliados 92

TABELA 5.11 - Comparação entre os grupos Experimental e Controle, em relação à proporção de casos com valores iguais ou superiores a $2 \mathrm{~mm}$, de deslocamento condilar, nos três planos do espaço 92

TABELA 1 (Anexo) - Valores originais dos deslocamentos condilares nos sentidos vertical, horizontal e transversal, do grupo Experimental 126

TABELA 2 (Anexo) - Valores dos deslocamentos condilares no sentido vertical, do grupo Experimental, corrigidos pelas variáveis idade cronológica e estágio de maturidade esquelética 127

TABELA 3 (Anexo) - Valores dos deslocamentos condilares nos sentidos vertical, horizontal e transversal, do grupo controle .128 
TABELA 4 (Anexo) - Idades cronológicas e índices de maturidade esquelética do grupo Experimental, ao início e ao término do uso das placas desprogramadoras. 129

TABELA 5 (Anexo) - Idades cronológicas e índices de maturidade esquelética do grupo Controle 130

TABELA 6 (Anexo) - Tempo de uso das placas desprogramadoras, no grupo Experimental 131 


\title{
LISTA DE ABREVIATURAS E SIGLAS
}

\author{
ATM - Articulação temporomandibular \\ DTM - Distúrbio da articulação temporomandibular \\ IPM - Indicador de posição mandibular \\ IPC- Indicador de Posição Condilar \\ MIC - Máxima Intercuspidação Habitual \\ RC- Relação Cêntrica
}

IPC vert D - Deslocamento condilar no sentido vertical, do lado direito

IPC vert E - Deslocamento condilar no sentido vertical, do lado esquerdo

IPC hor D - Deslocamento condilar no sentido horizontal, do lado direito

IPC hor E - Deslocamento condilar no sentido horizontal, do lado esquerdo

IPC transv - Deslocamento condilar no sentido transversal

$\mathrm{Rx}$ - radiografia

a - anos

$\mathrm{m}$ - meses 


\section{LISTA DE SÍMBOLOS}

$\mathrm{n}$ - Tamanho da amostra

D.P. - Desvio Padrão

P - Nível descritivo, em estatística

U - Representa a estatística, na Prova não paramétrica de Mann-Whitney

Z - Representa a estatística, na Prova não paramétrica de Wilcoxon

rs - Representa o coeficiente de correlação por postos de Spearman

"t" - Representa a estatística, no teste "t" de Student

$\mathbf{X}^{2}$ - Representa a estatística, no teste do Qui-quadrado

$\alpha$ - nível de significância estatística

* - Dado considerado significante 


\section{RESUMO}

\section{DESLOCAMENTOS CONDILARES ENTRE RC E MIC, COM E SEM DESPROGRAMAÇÃO, EM INDIVÍDUOS ASSINTOMÁTICOS, COM MALOCLUSÃO DE CL II}

Os deslocamentos condilares entre as posições mandibulares de RC e MIC são considerados ocorrências freqüentes na população em geral. Foram comparados, então, os deslocamentos condilares entre as duas posições citadas, em pacientes com maloclusão de Cl II de Angle (1899), sem sinais e sintomas clínicos perceptíveis de DTM, antes de realizarem-se os tratamentos ortodônticos. A amostra foi constituída por dois diferentes grupos. O grupo Experimental contou com 22 indivíduos distribuídos igualmente entre os sexos, com média de idade de 14a8m. Esses pacientes usaram placa oclusal desprogramadora por um período médio de $7 \mathrm{~m} 22 \mathrm{~d}$, antes de se realizarem os registros. O grupo Controle constituiu-se de 23 indivíduos, sendo 10 do sexo masculino e 13, do feminino, com média de idade de 16a8m. Esses últimos não usaram placas de desprogramação neuromuscular. Os deslocamentos condilares de ambos os grupos foram medidos nos três planos do espaço por meio de modelos montados em 
articulador semi-ajustável Panadent e do Indicador de Posição Condilar, de mesma procedência. Os deslocamentos condilares médios observados no grupo experimental, no sentido vertical, foram de $4,24 \mathrm{~mm}$ no lado direito e $3,86 \mathrm{~mm}$ no lado esquerdo. No sentido horizontal, aquelas medidas foram de 0,72mm no lado direito e de $-0,51 \mathrm{~mm}$ no lado esquerdo. No sentido transversal, obteve-se a medida de $0,03 \mathrm{~mm}$. Os deslocamentos condilares médios do grupo Controle mediram, no sentido vertical, $1,31 \mathrm{~mm}$ no lado direito e 1,86mm no lado esquerdo. No sentido horizontal, mediram -0,13mm do lado direito e $-0,11 \mathrm{~mm}$, do esquerdo. No sentido transversal, o valor médio foi de $-0,03 \mathrm{~mm}$. Foram encontradas diferenças estatisticamente significantes entre os grupos Experimental e Controle, apenas quando comparados os dados dos deslocamentos condilares no sentido vertical, dos lados direito e esquerdo, sendo significantemente maiores no grupo Experimental. Encontrou-se, também, diferença estatisticamente significante entre as medidas dos deslocamentos verticais do grupo Experimental, dos lados direito e esquerdo, sendo significantemente maiores no lado direito. Comparações entre homens e mulheres não revelaram diferenças estatisticamente significantes em relação aos deslocamentos estudados, assim como não se encontrou correlação entre tempo de uso das placas e os deslocamentos verticais do grupo experimental. Finalmente, encontrou-se correlação inversa significante entre idade cronológica e os deslocamentos condilares verticais dos lados direito e esquerdo, do grupo Experimental. A mesma correlação inversa significante foi observada entre maturidade esquelética e os referidos deslocamentos. Assim, quanto mais velhos ou 
maior a maturidade esquelética, menores os deslocamentos condilares no sentido vertical, encontrados nos pacientes daquele grupo. Confirma-se então, neste estudo, a ocorrência freqüente de deslocamento condilar entre RC e MIC, em pacientes com maloclusão de Cl II de Angle (1899), sem sinais e sintomas de DTM. Observou-se também, que com o uso das placas desprogramadoras, são evidenciados com maior nitidez, os deslocamentos condilares no sentido vertical, mesmo em pacientes assintomáticos. 


\section{INTRODUÇÃO}

O aprimoramento técnico-científico experimentado pela Ortodontia nas duas últimas décadas especialmente, e a maior conscientização demonstrada pelos pacientes, têm contribuído para níveis de exigência cada vez mais altos em relação ao resultados ortodônticos.

Um dos aspectos a merecer atenção de clínicos e pesquisadores trata da relação entre oclusão funcional e correção ortodôntica, e da atuação de ambas, como possíveis fatores etiológicos de distúrbios temporomandibulares (Ahlgren \& Posselt, 1963; Aubrey, 1968; De Boever \& Adriens, 1988; Jarabak, 1956; Randow et al.,1976; Roth, 1973; Roth, 1969; Thompson, 1956; Vallon et al., 1995).

Segundo alguns autores (Beyron, 1954; Ingervall, 1982; Roth, 1981a; Timm et al., 1976; Williamson, 1983) os objetivos ortodônticos devem incluir então, além dos resultados estéticos e do arranjo apropriado das arcadas, o estabelecimento de características próprias da "ótima oclusão funcional", tais como contatos múltiplos e equilibrados em relação cêntrica (RC) e em máxima intercuspidação (MIC) e movimentos irrestritos da mandíbula durante os movimentos funcionais entre outros. 
O diagnóstico ortodôntico constitui etapa de reconhecida importância no tratamento das maloclusões e tem evoluído de forma a corresponder aos requisitos da Ortodontia moderna, que se encontra em período de significantes transformações. Assim, o diagnóstico ortodôntico em relação cêntrica e os deslocamentos condilares entre ela e a posição mandibular de máxima intercuspidação, têm constituído tema de interesse, segundo se observa em alguns estudos publicados sobre o assunto (Arnett \& Bergman, 1993; Beyron, 1954; Chiappone, 1975; McCollum, 1939; Roth, 1981a; Wood, 1988).

Em busca de maiores informações que pudessem contribuir para um diagnóstico ortodôntico mais preciso, o presente trabalho tem a intenção de avaliar o deslocamento condilar entre as posições mandibulares de RC e MIC. Para tanto, foram considerados dois grupos de pacientes, tendo um deles sujeitado-se ao uso de placas desprogramadoras com finalidade de relaxamento neuromuscular. 


\section{REVISÃO DA LITERATURA}

Durante muito tempo, a relação cêntrica $(\mathrm{RC})$ foi definida como a posição mais retruída da mandíbula, e ainda, a posição fisiológica ideal, a partir da qual poderiam ser realizados movimentos de lateralidade (Gysi, 1910a; Gysi, 1910b; Sears, 1926; McCollum, 1939a; McCollum, 1939b; Stuart, 1939).

Gysi (1910a) parece ter sido um dos primeiros a discutir a importância de registrarem-se a "posição normal de repouso" da mandíbula, e os movimentos funcionais da mesma, para a construção de próteses totais. Para tanto, não só desenvolveu métodos de registro das posições consideradas, como empenhou sete anos de estudo, idealizando um articulador que reproduzisse individualmente, os trajetos condilares exibidos durante as funções mandibulares. Informa ainda que, à custa de experimentos precisos, foi demonstrado que a mandíbula, ao realizar pequeno movimento de abertura, permite que os côndilos permaneçam na posição normal de repouso. Consequentemente, o eixo de rotação localizase no côndilo, e apenas aquele ponto deve ser considerado, no movimento de abertura do articulador. Durante pequeno movimento de abertura mandibular, portanto, considera-se então, o verdadeiro ponto de rotação, 
onde a mandíbula ocupa uma posição distal normal, a partir da qual os movimentos laterais ou mastigatórios se iniciam.

Sears (1926) explica que força e coordenação musculares dependem em grande parte, da área na qual a mandíbula deve funcionar, sendo esta última, limitada pelas posições mandibulares de relação cêntrica, de protrusão, e de lateralidades direita e esquerda. Diz ainda, que a mandíbula está em RC quando situada na posição de repouso mais retruída, não forçada, a partir da qual os movimentos de lateralidade podem ser realizados. Segundo o mesmo autor, os profissionais que se recusam a adotar o registro de $\mathrm{RC}$ na construção de próteses totais, levantam as suspeitas de serem incapazes ou indiferentes àquele requisito essencial.

McCollum (1939a) considera o centro de abertura e fechamento da mandíbula, o fator mais importante na articulação dentária, devendo ser determinado antes da transferência do registro da relação maxilomandibular, para o articulador. Denomina o referido centro de rotação de "eixo de bisagra" e afirma que, embora constituam mecanismos biológicos, os movimentos mandibulares são mensuráveis, passíveis de registro, podendo ser reproduzidos por instrumentos mecânicos artificiais. Suspeita também, que o eixo de bisagra se mantenha constante por toda a vida. Menciona ainda, que, juntamente com outros membros da Sociedade Gnatológica da California, desenvolveu método para determinar-se o eixo de bisagra e apresenta estudos onde demonstra a existência de articulações que funcionam como verdadeiras dobradiças, cujos centros de rotação localizam-se em seus côndilos. Finalmente, aquele autor critica o 
entendimento deficiente apresentado pelos ortodontistas, sobre a função articular.

Para Stuart (1939), a mandíbula encontra-se em RC quando ambos os côndilos se assentam firmemente, em suas posições mais posteriores, nas fossas mandibulares.

Ricketts $(1950,1953,1955)$ estudou a variabilidade normal, tanto morfológica como funcional, da articulação temporomandibular, por meio de cefalometria laminográfica de 100 indivíduos, divididos em grupos com oclusão normal, com maloclusão de $\mathrm{Cl}$ II e de Cl III de Angle. Os indivíduos foram avaliados nas posições de repouso fisiológico, de oclusão dentária e de máxima abertura bucal.

O autor citado constatou que as superfícies articulares apresentam-se usualmente regulares, e que os côndilos encontram-se geralmente, centralizados nas fossas mandibulares, na posição de oclusão dentária. Aquelas poderiam ser consideradas então, características de articulações ideais ou representativas de uma condição média, em indivíduos com oclusões normais, com maloclusões de Cl I, CL II ou Cl III, de Angle (1899). Encontrou porém, variações nos indivíduos com maloclusão de $\mathrm{Cl}$ II especialmente, e com Cl III, ao analisar os deslocamentos condilares entre as posições de repouso fisiológico e de contato dentário. Nestes casos, os côndilos localizaram-se com freqüência, numa posição mais ântero-inferior e póstero-superior respectivamente, quando registrada a posição de repouso fisiológico da mandíbula. Os indivíduos com maloclusão de Cl II, mostraram 
os maiores deslocamentos condilares entre as posições de repouso e de oclusão dentária.

Dawson (1974) introduziu importante mudança no conceito de RC, definindo-a como a posição mais ântero-superior que os côndilos podem assumir na fossa mandibular e estabeleceu quatro requisitos que caracterizam aquela posição, em articulações saudáveis:

- Discos corretamente alinhados em ambos os côndilos.

- Conjunto côndilo-disco assentado no ponto mais alto possível, contra a vertente posterior da eminência articular.

- Polo medial de cada conjunto côndilo-disco, suportado por osso.

- Músculo pterigóideo lateral inferior relaxado e passivo.

Ainda segundo Dawson (1974), partindo de RC, qualquer movimento de sentido anterior ou posterior, resulta automaticamente, em deslocamento inferior do côndilo.

Weinberg (1979) subdivide a relação cêntrica em funcional e não funcional. Em ambas as circunstâncias os côndilos encontram-se corretamente posicionados nas respectivas fossas, porém, no último tipo, o disco articular relaciona-se de forma imprópria com as demais estruturas internas da articulação.

Williamson et al. (1979) apud Roth (1981a) confirmam por meio de estudo eletromiográfico, que a posição fisiológica dos côndilos na fossa mandibular, determinada pela musculatura, é súpero-anterior. Desta forma, os referidos côndilos assentam-se contra a parede inclinada póstero-superior da eminência articular. 
Roth (1981a) concorda com as considerações feitas por Dawson (1974) sobre a nova definição de RC. Lamenta porém, que o aspecto mais enfatizado da definição de relação cêntrica tenha sido, durante anos, a localização mais posterior, em vez de superior, dos côndilos na fossa mandibular. Acredita por isto, que muitos pacientes, supostamente tratados respeitando-se a RC, apresentam ainda, sintomas de disfunção temporomandibular.

Gilboe (1983) considera RC a posição mais superior do côndilo na fossa mandibular, com a área central do disco em contato com as superfícies articulares do côndilo e da eminência.

Considerando como posição clinicamente relevante, Gilboe (1983) justifica a definição de RC descrita, analisando aspectos morfológicos e da matriz funcional, relacionados ao complexo composto pelo côndilo, tecidos intra-articulares e eminência articular.

Schweikert (1985) informa ser a relação cêntrica, geralmente definida como a posição mais superior que os côndilos podem alcançar na fossa mandibular. Esclarece que a RC, mais precisamente, ocupa o limite extremo póstero-superior que os côndilos podem alcançar, na parede inclinada posterior da eminência articular, com o disco interposto. Informa ainda, que a RC independe da relação oclusal dos dentes.

No glossário de termos da The Academy of Denture Prosthetics (1987) a relação cêntrica é considerada a relação maxilo-mandibular na qual os côndilos se articulam com a região mais fina e avascular dos respectivos 
discos, estando o conjunto, numa posição ântero-superior, contra a vertente posterior da eminência articular.

Ide \& Nakazawa (1991) criticam a antiga definição de relação cêntrica, pois não consideram que a posição condilar mais retruída na fossa mandibular seja funcional. Justificam que, naquela situação, o côndilo pode comprimir ou estimular a zona bilaminar posterior, constituída por abundantes vasos e nervos. Os autores afirmam também, não haver nenhuma articulação no corpo, cujas partes funcionais dos ossos se encontrem separadas umas das outras, o que ocorreria segundo a definição original de relação cêntrica.

Becker \& Kaiser (1993) analisam a evolução dos conceitos de oclusão e dos instrumentos relacionados a ela, mencionando as diversas escolas modernas de pensamento. Os autores informam que as divergências sobre as definições de RC, resultaram no aparecimento de diferentes "sinônimos", na literatura

De acordo com Van Blarcom (1994), RC é definida como a relação maxilo-mandibular na qual os côndilos se articulam com a porção mais fina e avascular dos respectivos discos, com esse conjunto ocupando posição ântero-superior, contra a vertente posterior da eminência articular. É considerada posição que independe do contato dentário, sendo discernível clinicamente, quando a mandíbula for dirigida superior e anteriormente, restrita a um movimento de rotação em torno de um eixo horizontal transverso. 
Dawson (1995) reafirma os critérios para obtenção da relação cêntrica publicados anteriormente (Dawson, 1974), explicando que os mesmos se aplicam a articulações íntegras e saudáveis. Introduz também, a nova expressão "postura cêntrica adaptada", destinada às articulações com diferentes graus de alterações estruturais que, apesar delas, podem ainda, funcionar confortavelmente. Finalmente, informa que na presença de determinadas condições patológicas, pode ser impossível alcançar-se a RC ou a postura cêntrica adaptada, sendo preciso então, determinar-se uma posição articular de tratamento específica para cada caso.

Segundo Neff (1995), a definição de RC publicada no glossário de termos da The Academy of Denture Prothetics (1987) foi aceita pela Federação dos Órgãos de Prótese, que representa diversas academias e sociedades tais como a Sociedade de Equilíbrio Americana e a Sociedade Gnatológica do Nordeste dos EUA.

Em substituição ao termo "RC", Okeson (1998) refere-se à posição de ótima estabilidade ortopédica da mandíbula, como "posição de estabilidade músculo-esquelética". Diz também, que a referida posição requer a localização mais ântero-superior dos côndilos nas fossas mandibulares, com o disco adequadamente interposto. Informa estar de acordo com grande parte da definição de RC proposta por Dawson (1995), não acreditando porém, que a qualquer movimento ântero-posterior dos côndilos, haja concomitante deslocamento inferior dos mesmos. Afirma que aquele fenômeno só ocorre em articulações jovens e sadias. Na presença de flacidez ou alongamento do ligamento temporomandibular, pode-se observar 
deslocamento ântero-posterior dos côndilos, sem que os mesmos abandonem a porção mais superior das respectivas fossas mandibulares. Recomenda então, que se dê ênfase à localização ântero-posterior dos côndilos, ao registrar-se a posição de estabilidade ortopédica da mandíbula, sempre necessária quando indicada terapia oclusal permanente.

A RC tem sido considerada importante posição de referência na execução de diversos procedimentos odontológicos. Segundo alguns autores, a máxima intercuspidação dentária deve ocorrer com os côndilos em RC, referindo-se a este fenômeno como "coincidência entre RC e MIC" (Arnett \& Bergman, 1993; Beyron, 1954; Roth, 1981a; Roth, 1981b; Wood, 1988).

Schuyler (1929, 1954) afirma que a RC constitui importante referência na reconstrução parcial ou total dos dentes, no alívio do trauma oclusal e nos tratamentos ortodônticos. Em função da freqüente desarmonia entre RC e MIC, em pacientes jovens com maloclusão, recomenda a avaliação daquela discrepância por meio da montagem de modelos em articulador, para que a mesma possa ser eliminada, ao mesmo tempo em que se corrigem a forma das arcadas e as relações oclusais. Acrescenta então, que a eliminação da discrepância entre RC e MIC poderia contribuir para maior estabilidade dos resultados ortodônticos, quando removidos os aparelhos de contenção.

Ao definir as características da ótima oclusão funcional e descrever princípios da reabilitação oclusal, Beyron (1954) declara ser mais importante promover perfeitas condições funcionais do que anatômicas, do aparelho 
mastigatório. Estabelece portanto, como primeiro critério da ótima oclusão, o fechamento mandibular em RC. Explica que, durante o fechamento naquela posição, ocorrem ocasionalmente, contatos prematuros, observando-se em seguida, deslize mandibular em direção a uma posição de intercuspidação "incorreta". Naquela circunstância, a sobrecarga nos dentes em contato prematuro e o deslize mandibular para uma posição forçada, resultam em estresse desfavorável dos tecidos periodontais, ao mesmo tempo em que perturbam a ATM.

Roth (1973) afirma que o esquema oclusal relacionado em cêntrica e mutuamente protegido, alcançado com exatidão, constitui meio efetivo de correção de distúrbio temporomandibular induzido pela oclusão. Lembra ainda, que a oclusão parece exercer papel mais importante na produção de distúrbios da ATM, do que o descrito até então. O autor apresenta ainda, método efetivo de ajuste oclusal e explica que as interferências oclusais comumente associadas ao DTM se devem a falhas na correção da relação ântero-posterior entre as arcadas, ao torque lingual insuficiente dos primeiros e segundos molares superiores, ao torque lingual excessivo dos molares inferiores e à descoordenação entre forma e dimensão das arcadas, quando relacionadas em $\mathrm{RC}$.

De acordo com Lauritzen (1974), a coincidência entre RC e MIC é característica básica da oclusão ideal, sendo esta relação a única posição de oclusão, sem conflitos entre as guias temporomandibulares e as superfícies oclusais dos dentes. Quando existe harmonia entre aqueles fatores, o comportamento muscular é ideal. 
Chiappone (1975) critica a ortodontia por negligenciar os aspectos estáticos e dinâmicos da oclusão, na fase de finalização dos tratamentos ortodônticos. Considera fundamental assegurar que a oclusão dos pacientes esteja em harmonia com a ATM, e que RC coincida com MIC.

Para Timm et al. (1976), o tratamento ortodôntico afeta todos os componentes do sistema mastigatório. Assim, o conhecimento sobre oclusão, necessário para o ortodontista, deve ir além da simples classificação anatômica das maloclusões. Os autores consideram a RC, a posição chave de referência que permite ao ortodontista, estabelecer relação equilibrada entre oclusão, ATM e sistema neuromuscular. Para eles, a discrepância entre RC e MIC poderá ser de até $1 \mathrm{~mm}$, e o deslocamento condilar entre ambas as posições deve estar contido no mesmo plano horizontal.

Para Aubrey (1978), os objetivos do tratamento ortodôntico deveriam ir além da oclusão ideal descrita por Angle (1899) produzindo oclusões em harmonia com os mecanismos que sustentam a mandíbula. Para alcançar os referidos objetivos, considera imperativo finalizar as correções ortodônticas em oclusão de relação cêntrica, ou seja, com a máxima intercuspidação dentária coincidente com a posição mandibular de RC. Justifica que, ao se adotar a máxima intercuspidação como ponto de partida para o diagnóstico ortodôntico, corre-se o risco de exigir certo grau de adaptação condilar, impossível de ser tolerado indefinidamente. Indica ainda, o ajuste da oclusão ao final das correções ortodônticas, sempre que presentes possíveis interferências funcionais. 
Fazendo considerações sobre o conceito de RC num contexto biológico, Moffett (1978) informa que a adoção da mesma como referência para as reconstruções oclusais, justifica-se pelo fato das posições bordejantes reproduzirem-se mais facilmente, além de haver uma quase coincidência entre RC e a posição habitual de contato oclusal. Afirma não haver qualquer aspecto que desqualifique biologicamente, a prática terapêutica de eliminar-se ou reduzir-se a discrepância entre RC e MIC. Cita finalmente, outras articulações do corpo humano, que funcionam em posições bordejantes, como as articulações do quadril, na posição ereta do corpo, ou do cotovelo, quando se carrega algo pesado.

Para o correto diagnóstico de pacientes ortodônticos, Parker (1978) considera prudente, a montagem de modelos em RC, em articulador semiajustável, a fim de avaliar a possível coincidência entre aquela posição e a adotada pela mandíbula, quando em MIC. Menciona em conseqüência que, independentemente das controvérsias envolvendo os fatores etiológicos dos distúrbios articulares, o ortodontista deve manter-se alerta, sempre que aquelas posições forem incongruentes. Apresenta em seguida, diversos casos clínicos de pacientes, cujos problemas funcionais ou articulares não foram avaliados devidamente, antes das correções ortodônticas. Discute a inter-relação entre ortodontia e os conceitos de oclusão funcional vigentes, apontando eventuais dificuldades e limitações dos tratamentos ortodônticos, na busca daquelas metas funcionais.

De acordo com Ingervall (1982), a oclusão gerada pelo tratamento ortodôntico deve preencher dois critérios básicos: os côndilos mandibulares 
devem estar centralizados na fossa mandibular durante a máxima intercuspidação, e não deve haver atividade muscular desnecessária na posição mencionada. Segundo ele, para que os côndilos sejam considerados centralizados, o deslocamento entre RC e MIC deve ser, no máximo, de 0,4mm. Recomenda então, avaliarem-se aqueles dois critérios, antes, durante e ao final dos tratamentos ortodônticos, e enfatiza que a correção das maloclusões só deve ser considerada encerrada, quando cumpridos os critérios descritos. Alerta também, que o ortodontista tem a oportunidade única de corrigir oclusões funcionalmente insatisfatórias, sendo essencial, portanto, integrar-se o enfoque funcional da maloclusão à ortodontia.

Williamson (1983) afirma que o tratamento ortodôntico deve ter como objetivo, a restauração e a preservação da $\mathrm{RC}$, além da economia de energia neuromuscular, durante a função oclusal. Por isto, o autor sugere, além do estudo da documentação ortodôntica tradicional, a montagem dos modelos em articulador, a fim de verificarem-se as relações condilares, oclusais e funcionais.

Segundo Capp \& Clayton (1985a), a recuperação ou o ajuste da oclusão, mantendo-se relação maxilo-mandibular incorreta, resulta em contatos deflectivos. Aqueles contatos podem, por sua vez, causar distúrbio da ATM, impedir o alcance de posições bordejantes, precipitar o bruxismo, acelerar o desgaste das coroas dentárias e produzir mobilidade excessiva dos dentes. Os autores descrevem ainda, um método indireto de detecção do primeiro contato oclusal, em RC. 
Wood (1988) considera a RC, o ponto de referência que permite relacionar acuradamente, os modelos dos pacientes de reabilitação bucal, em consultas sucessivas. Considera-a também, relação fisiológica entre as estruturas constituintes das articulações temporomandibulares saudáveis. Enfatiza que os tecidos que suportam e controlam a ATM, reagem ao estresse e se recuperam dele, da mesma forma que outros tecidos do corpo. Os indivíduos cujos tecidos bucais e da ATM foram agredidos por longo período de tempo, demonstram anormalidades evidentes, portanto, de fácil detecção. Aquelas alterações exigem um programa amplo de tratamento, que deve anteceder a reabilitação oclusal propriamente dita. Já, as anormalidades menores podem ser de difícil diagnóstico, constituindo assim, um risco desconhecido, quando realizadas reabilitações bucais. Wood (1988) indica então, o tratamento, o condicionamento e a estabilização dos tecidos afetados, antes de realizarem-se registros finais do eixo transversal horizontal, dos traçados pantográficos e da relação interoclusal, pretendendo dar àquelas estruturas, a oportunidade de alcançar ótima saúde fisiológica antes de iniciar qualquer tratamento irreversível da oclusão.

Na publicação Basics (1993), relacionada à dentística cosmética, adesiva e restauradora, são recomendadas algumas seqüências de tratamento, em busca de relações saudáveis, funcionais e não destrutivas entre dentes, articulações e músculos relacionados. Naquele mesmo artigo, a RC é considerada o melhor ponto de partida para diagnóstico e plano de tratamento, devendo coincidir com MIC sempre que possível, especialmente quando planejadas extensas reconstruções dentárias. Justifica-se que 
nenhuma outra referência além de RC, seja reproduzível com tamanha consistência. Em alguns pacientes, particularmente naqueles com articulações flácidas, a RC pode ser substituída pela liberdade em cêntrica. Informa-se ainda, que em cerca de $90 \%$ da população é encontrada discrepância entre RC e MIC, e ao restaurar a oclusão, são mencionadas duas possibilidades: a de manter a máxima intercuspidação original, classificada como "oclusão desorganizada", ou promover a coincidência entre RC e MIC, considerada "oclusão reorganizada". Pacientes assintomáticos permaneceriam em "oclusão desorganizada" e os sintomáticos deveriam ser tratados.

Segundo Arnett \& Bergman (1993), o trabalho do ortodontista é o de coordenar a correção oclusal, a saúde periodontal, a função da articulação temporomandibular, a estabilidade e o equilíbrio facial, enquanto movimenta dentes. Para isto, todos os dados diagnósticos deveriam ser registrados em relação cêntrica, uma vez que os resultados ortodônticos e cirúrgicos devem estar estritamente nesta posição, para que a função resultante seja precisa.

Diante da explosão de novas informações sobre produtos, técnicas e tecnologias experimentada pela dentística restauradora, Parker (1993) expressa preocupação ao observar, em número excessivo de publicações, a tendência dos autores omitirem importantes considerações sobre oclusão. Segundo ele, trata-se de tendência perigosa pois, a oclusão exerce profundo efeito sobre o resultado da maioria das restaurações dentárias, especialmente, as próteses sobre implante. Identificando conceitos de oclusão aceitos atualmente pela maioria dos pesquisadores, menciona ainda 
que, após evolução da definição de RC, observa-se convergência de opiniões sobre a posição mandibular ideal de tratamento. Acrescenta em seqüência, que a máxima intercuspidação poderia ser adotada como posição de tratamento, desde que considerada fisiológica e que o trabalho restaurador se limite a pequenas áreas oclusais. Quando a MIC não for julgada fisiológica ou as restaurações envolverem extensas áreas oclusais, a posição mandibular de referência deve ser a de RC. Finaliza informando que a máxima intercuspidação é considerada fisiológica quando presentes as seguintes características:

- Fácil manipulação mandibular em RC.

- MIC localizada em área de até 0,5mm, à frente de RC.

- Ambas articulações livres de história de dor ou restrição de movimento mandibular.

- Ausência de sinais e sintomas de trauma oclusal primário tais como aumento de mobilidade, frêmito, perda óssea angulada ou desgaste dentário excessivo.

- Ausência de sensibilidade à palpação dos músculos elevadores da mandíbula, dos pterigóideos laterais e das ATM.

Dawson (1995) salienta a importância da RC nos tratamentos oclusais e advoga precisão ao localizá-la pois, mesmo a menor deflecção mandibular pode retirar os côndilos do suporte ósseo e ativar a contração descoordenada dos músculos pterigóideos laterais inferiores, em oposição à dos músculos elevadores da mandíbula. Esclarece também que a extraordinária sensibilidade dos sensores proprioceptivos periodontais e 
interdentais, pode desencadear padrões musculares de dor reflexa, a partir de interferências oclusais deflectivas. Muitas vezes, aquelas interferências passam despercebidas pelos clínicos, que não reconhecem sua importância, ou a importância de verificar-se a exatidão da RC, antes de iniciar qualquer procedimento de correção oclusal.

Chang et al. (1997) julgam insuficiente o emprego da documentação ortodôntica padrão para realizar um diagnóstico ortodôntico confiável e salientam a importância de avaliar-se a correta postura mandibular, com aquela finalidade. Os autores descrevem quatro casos, cujos diagnósticos e planos de tratamento feitos à partir da documentação ortodôntica convencional, exigiram reavaliação, ao constatar-se a ocorrência de mordida dupla. Dos quatro planos previamente elaborados, três foram modificados e um confirmado, depois de avaliar-se a posição dos côndilos nas respectivas fossas mandibulares, definir-se a verdadeira relação maxilo-mandibular e consequentemente, a real maloclusão.

Okeson (1998) afirma que a alteração permanente da oclusão está indicada, quando se pretendem melhorar as relações estéticas e funcionais entre maxila e mandíbula, ou no tratamento de pacientes com DTM, nos quais se tenha evidenciado que aspectos oclusais constituem fator etiológico da mesma.

Nem todos autores adotam a coincidência entre RC e MIC, como meta de tratamento. Para alguns, os côndilos devem localizar-se ligeiramente à frente de $\mathrm{RC}$, quando estabelecido o máximo contato dentário 
habitual. Tal conceito é advogado pela escola da "cêntrica longa", da "liberdade em cêntrica", ou da "liberdade a partir de cêntrica".

De acordo com Celenza (1978), o suporte máximo da mandíbula ocorre na posição de máxima intercuspidação, quando ocorre o mais alto grau de atividade muscular, durante a mordida supertensa. Entende que MIC, normalmente não coincide com a posição condilar de RC e informa que MIC é a posição de máxima estabilidade dos dentes, do sistema neuromuscular e das ATM, não localizada em posição bordejante. Define "cêntrica longa" como a liberdade de fechar a mandíbula tanto em RC, como ligeiramente à frente dela, sem que varie a dimensão vertical da oclusão, esclarecendo que, enquanto o limite posterior da área do preparo dentário seja definível e justificável, os limites anterior e laterais não o são. Aqueles últimos são selecionados arbitrariamente, constituindo contatos excêntricos, incorporados na área de cêntrica.

Discutindo a natureza dos contatos oclusais segundo a escola da cêntrica longa, Celenza (1978) informa que os trajetos mandibulares são todos curvilíneos e em ângulo, em relação ao plano horizontal. Este fato torna impossível a construção de áreas cêntricas nos dentes, que promovam contato contínuo em toda sua extensão, a não ser que a mesma também seja curva. Torna-se então, mecanicamente impossível construir uma área cêntrica de acordo com a definição de cêntrica longa, devendo ocorrer contatos desequilibrados ou falta de contato na referida área.

Para Celenza (1978) ainda, a falta de equilíbrio oclusal criada não é saudável do ponto de vista fisiológico e justifica a aceitabilidade clínica da 
cêntrica longa, pela capacidade de adaptação do paciente. Conclui que seria mais razoável e menos conflitante do ponto de vista científico, construíremse contatos oclusais os mais precisos possíveis mecanicamente, coincidentes com a posição condilar de tratamento selecionada. Desta forma, os contatos bilaterais equilibrados reforçariam e auxiliariam na adaptação àquela posição, provavelmente não natural, mas aceitável, dos côndilos.

Guichet (1978) afirma que o objetivo do tratamento oclusal é o de estabelecer oclusão fisiológica. Aquela seria a oclusão suficientemente harmônica em relação à função mandibular, de forma a evitar que sejam induzidos desarranjos ou sintomas do sistema estomatognático. Ensina, que contatos oclusais específicos programam respostas musculares específicas, e que o caráter do contato dentário quantifica a resposta muscular. Assim, o critério para avaliar-se a validade de qualquer relação oclusal proposta, não se encontra em especificações da própria oclusão, mas na resposta muscular decorrente do esquema oclusal escolhido. $\mathrm{O}$ objetivo do tratamento oclusal é, em última instância, o de alcançar a liberdade neuromuscular da mandíbula. Ainda segundo o autor, observações clínicas deveriam revelar que a maioria dos pacientes apresenta deslocamento anterior da mandíbula, no fechamento em RC. Para ele, a "posição condilar ótima", na maioria dos pacientes, localiza-se em algum lugar próximo de RC, mas não coincidente com ela. A definição da posição condilar ótima, durante a máxima intercuspidação, requer certo intervalo de aceitação fisiológica individual, que o autor desconhece qual seja. Guichet (1978) afirma porém, 
que aquela posição é alcançada mais facilmente, via RC, devendo localizarse afastada desta última, num intervalo de até 1/4mm.

Ramfjord (1978) explica que até a publicação da monografia de Posselt, em 1952, não se questionava, nos círculos de prótese, o conceito adotado até então, segundo o qual, os procedimentos restauradores deveriam ser realizados buscando-se a coincidência entre RC e MIC. O contato deslizante entre aquelas duas posições era considerado fenômeno patológico, devendo ser rotineiramente corrigido.

De acordo com Ramfjord (1978), Posselt (1952) constatou que a relação cêntrica constitui posição retrusiva bordejante, não coincidindo com MIC, em indivíduos com oclusão normal. Originam-se aí, as bases empíricas do conceito da "cêntrica longa", denominado posteriormente, "liberdade em cêntrica" ou "liberdade a partir de cêntrica".

Ramfjord (1978) afirma não se ter surpreendido com a existência da usual discrepância entre RC e MIC constatada, pois, segundo ele, nenhuma articulação funciona otimamente, numa posição bordejante. Para ele, o termo "liberdade em cêntrica" refere-se ao padrão oclusal que permite movimento ântero-posterior entre RC e MIC, num mesmo nível vertical, mantendo-se contato entre os dentes posteriores. A "liberdade em cêntrica" deve permitir também, movimento de deslize suave e livre, num pequeno plano horizontal achatado, entre a nova MIC e aquela existente antes do tratamento, assim como até a RC. Salienta este autor, que o conceito de "cêntrica longa" ou "liberdade em cêntrica" não existe na oclusão normal de seres humanos, representando um princípio de conveniência, a ser adotado 
em pacientes que necessitem de reabilitação bucal. O referido conceito não deve ser imposto a pacientes que não exibam sinais e sintomas de trauma oclusal ou requeiram reconstrução oclusal. Cita como vantagens do conceito de "liberdade em cêntrica" sobre a "cêntrica justa", o menor desgaste dentário exigido durante o ajuste oclusal, a manutenção da dimensão vertical da oclusão original e a razoável segurança acerca da futura estabilidade funcional da oclusão. Os procedimentos técnicos envolvidos são também, mais simples, dispensando-se traçados pantográficos dos movimentos mandibulares, inclusive do deslocamento de Bennett, permitindo que as restaurações sejam completadas em articulador semi-ajustável.

Finalmente, ao realizar reabilitação oclusal da boca toda, o autor (Ramfjord, 1978) explica que, após o preparo dentário e a construção de todas coroas provisórias, realiza moldagens, recoloca os provisórios e obtém os registros de RC, montando os modelos naquela posição. Em seguida, move o mecanismo condilar do articulador, para frente, arbitrariamente, entre 0,2 e 0,3mm, fazendo então, o enceramento das coroas, nessa posição anterior. Segundo sua experiência clínica, a distância entre RC e MIC não é crítica, desde que varie entre 0,1 mm e 0,5mm.

O grau de discrepância entre RC e MIC, nos diferentes tipos populacionais, tem sido objeto de estudo, assim como as possíveis relações entre posição condilar e distúrbios oclusais, musculares ou articulares.

Hoffman et al. (1973) avaliaram os padrões de variação condilar entre as posições de RC e MIC, nos três planos do espaço. Foram selecionados 52 indivíduos do sexo masculino, com idades entre 22 e 46 anos, com boa 
oclusão natural posterior, sem história de tratamento ortodôntico nem maloclusão grosseira que exigisse aquele tipo de intervenção, com restaurações e desgastes dentários mínimos, com periodonto saudável e sem aparente patologia da ATM. O eixo de rotação mandibular foi localizado cinemáticamente em 6 indivíduos e, nos demais 46, adotou-se o eixo estimado, para a montagem em articulador, dos modelos superiores. Os modelos inferiores foram montados em posição de máxima intercuspidação. Os registros de $\mathrm{RC}$ foram obtidos manipulando-se a mandíbula segundo a técnica "guia da ponta do mento", e as discrepâncias condilares entre RC e MIC foram medidas por meio de espessímetros, em instrumento desenvolvido com aquela finalidade. Os autores encontraram diferença média entre RC e MIC, no sentido ântero-posterior de 0,28mm, com discrepância máxima de 0,95mm, exibida por um indivíduo. No sentido vertical, metade dos indivíduos exibiu RC acima de MIC, e a outra metade, abaixo desta posição. O deslocamento superior médio foi de $0,26 \mathrm{~mm}$, com valor máximo de $0,61 \mathrm{~mm}$, e o deslocamento inferior médio foi de $0,24 \mathrm{~mm}$, com discrepância máxima de 0,53mm. Observou-se ainda, deslocamento médio-lateral médio de 0,1mm, com deslocamento máximo de 0,3mm. Comparando-se os valores dos lados direito e esquerdo, observou-se diferença de deslocamento ântero-posterior igual ou maior que 0,1mm, em $77 \%$ dos indivíduos, sendo que em 10\% deles, a diferença entre os lados foi maior que $0,5 \mathrm{~mm}$. As assimetrias entre os lados direito e esquerdo, encontradas no plano vertical, apresentaram valores semelhantes aos do 
plano horizontal. Finalmente, o erro do método decorrente da montagem dos modelos segundo eixos estimados de rotação foi da ordem de 0,1mm.

Acreditando na associação entre interferências oclusais e DTM, em pacientes ortodônticos, Roth (1973) identificou os tipos mais freqüentes daquelas alterações. Segundo ele, parece haver associação entre severidade e localização dos sintomas de DTM e a localização das interferências em balanceio. O autor informa também, que parece ser bastante rara a ocorrência de DTM, na ausência de interferências oclusais. Finalmente, afirma que o estabelecimento preciso do esquema oclusal relacionado em cêntrica e mutuamente protegido, consiste num meio efetivo de corrigir os distúrbios temporomandibulares induzidos por fatores oclusais.

Considerando obscuro o significado da relação entre côndilo e fossa mandibulares, Pullinger et al. (1985) estudaram aquela relação em população assintomática, por meio de tomografia linear. A amostra foi constituída de 28 indivíduos do sexo masculino e 26 do feminino, livres de distúrbios mastigatórios, sem coroas protéticas em molares, e sem história de tratamento ortodôntico ou de ajuste oclusal. Segundo os autores, os côndilos apresentaram-se concêntricos em 50\% a 65\% dos indivíduos, com considerável grau de variabilidade. A distribuição de côndilos não concêntricos variou segundo o sexo, localizando-se mais anteriormente nos homens e, mais posteriormente, nas mulheres. Os autores lembram que, estudos epidemiológicos ou feitos por meio de autópsia, indicam maior incidência de sons articulares e de deslocamento de disco, entre as mulheres. Lembram ainda, que o deslocamento posterior dos côndilos 
poderia gerar predisposição mecânica para o deslocamento anterior do disco. Suspeitam então, que as mulheres estariam mais predispostas àquele distúrbio articular, e que a retroposição condilar, encontrada em casos de distúrbios internos da ATM, seria uma condição preexistente e não a conseqüência do deslocamento do disco. Finalmente, os autores salientam que o diagnóstico de DTM não pode basear-se apenas em achados radiográficos, uma vez que foram encontrados côndilos tanto centralizados como deslocados, em população assintomática.

Em revista da literatura, Weinberg (1985) encontrou alta incidência de deslocamento posterior dos côndilos, em casos de dor-disfunção aguda da ATM (53\% a 70\%), sendo bem mais baixa nos grupos controle. Ele apresenta vários casos clínicos de pacientes com sinais e sintomas articulares, tratados com sucesso, reposicionando-se os côndilos nas fossas mandibulares por meio de ajustes oclusais ou prótese. O autor esclarece porém, que o freqüente deslocamento condilar mencionado não constitui fator patognomônico de distúrbio da ATM, não devendo ser adotado como meio de diagnóstico daquela alteração.

Em continuidade ao estudo sobre a importância da relação côndilofossa mandibulares, Pullinger et al. (1986) avaliaram a posição condilar, por meio de tomografia linear, em três grupos com distúrbios temporomandibulares, assim classificados: grupo com mialgia, grupo com distúrbio da ATM e grupo com artrose, num total de 102 pacientes. Os autores observaram maior freqüência de côndilos concêntricos no grupo com mialgia, e deslocados posteriormente, no grupo com distúrbio articular. 
No grupo com artrose, encontraram ampla distribuição de posição condilar. A localização posterior do côndilo foi considerada fator predisponente da instabilidade do disco, embora a variabilidade de posição representada em cada grupo, desqualifique o método radiográfico, como principal meio de diagnóstico de DTM.

Em seqüência de trabalhos anteriores, Pullinger et al. (1987) estudaram a possível relação entre posição condilar e fatores oclusais, tais como tipo de maloclusão de Angle (1899), grau de sobremordida e de sobressaliência, a coincidência ou discrepância entre as linhas médias superior e inferior, além da quantidade de deslize entre RC e MIC. A mostra adotada foi a mesma de estudo anterior (Pullinger et al., 1985), com indivíduos sem sintomas de DTM. Os autores encontraram associação entre a maloclusão de Cl II e côndilos não concêntricos, onde a maloclusão de CL II div. $1^{\text {a }}$ especialmente, mostrou-se associada a maior deslocamento condilar de sentido anterior. As demais variáveis analisadas não demonstraram correlação com a posição condilar.

Rosner \& Goldberg (1986) compararam as posições condilares registradas em MIC e em $\mathrm{RC}$, em 75 indivíduos, sem história de tratamento cirúrgico da ATM, com diferentes tipos de maloclusão de Angle (1899) e apresentando relação estável de modelos em MIC. A média de idade da amostra foi de 44 anos. A análise das posições condilares foi feita, montando-se modelos de gesso no articulador Whip-Mix modificado, por meio de arco facial e de registros de RC, obtidos segundo a técnica guiada do mento. Os autores (Rosner \& Goldberg, 1986) constataram grande 
dispersão dos registros, que se refletiu estatísticamente, em amplos desvios padrões. Noventa por cento dos registros de MIC ocorreram abaixo dos de RC, localizando-se nos quadrantes inferiores. Sessenta por cento dos registros ocorreram no quadrante ântero-inferior e 30\%, no póstero-inferior. Os demais 10\% localizaram-se no quadrante ântero-superior. Os deslocamentos médios observados foram de $0,26 \mathrm{~mm}$ em sentido anterior, de $0,78 \mathrm{~mm}$ em sentido inferior e de $0,34 \mathrm{~mm}$ em sentido médio-lateral. Cerca de $45,3 \%$ dos indivíduos avaliados apresentaram diferença maior que $0,7 \mathrm{~mm}$, quando comparados os deslocamentos condilares horizontais, dos lados direito e esquerdo. Em sentido inferior, aquele grau de diferença ocorreu em 25,3\% da amostra. Os demais indivíduos apresentaram diferenças entre os lados direito e esquerdo, que variaram entre 0 e $0,7 \mathrm{~mm}$, nos planos horizontal e vertical. Quase metade da amostra apresentou deslocamento médio-laterial entre 0 e $0,3 \mathrm{~mm}$. Aquele deslocamento variou entre $0,3 \mathrm{~mm}$ e $0,6 \mathrm{~mm}$ em $38 \%$ dos indivíduos e $12 \%$ demonstraram deslocamento médio-lateral maior que $0,6 \mathrm{~mm}$. Os autores concluem que, a combinação de movimentos assimétricos horizontais, verticais e de deslocamentos médio-laterais dificultam a determinação da posição condilar a partir da linha média.

Johnston et al. (1988) compararam a incidência de deslizes entre RC e MIC, de pacientes ortodônticos com a de indivíduos não tratados. A amostra foi constituída por 175 estudantes, com média de idade de 25 anos e 6 meses, onde 95\% eram do sexo masculino. Os participantes usaram placa oclusal por duas semanas, antes do registro de $\mathrm{RC}$, sendo este, obtido 
segundo método de Dawson. Os modelos foram montados em articulador Whip-Mix, aparentemente, por vários operadores. Os deslocamentos entre RC e MIC foram medidos sobre os dentes, por dois operadores, e determinou-se o deslize médio entre as posições em estudo. Os autores encontraram deslizes entre RC e MIC maiores que os relatados na literatura, e acreditam que tal diferença possa ser decorrente do uso das placas oclusais, favorecendo maior reposição condilar em RC. Não se constatou diferença significante entre os dois grupos considerados, pois, os deslizes apresentados pelos pacientes ortodônticos não foram maiores que dos indivíduos do grupo controle. Comparando os resultados encontrados com os de outros estudos, fazem em seguida, algumas inferências. Segundo os autores, as discrepâncias entre RC e MIC tendem a recidivar quando alteradas e que, por isto, aquelas discrepâncias poderiam constituir característica intrínseca do envelope individual de movimentação. Assim sendo, os tratamentos oclusais deveriam ser planejados para evitar qualquer aumento daquela discrepância, e não, para eliminá-los.

Abrão (1991) analisou diversos aspectos relacionados à oclusão funcional, em 15 pacientes tratados ortodonticamente pela técnica do Arco de Canto, tanto por meio de avaliação radiográfica das ATM como da montagem de modelos em articulador. As diferenças médias entre as posições condilares de RC e MIC foram de $0,36 \mathrm{~mm}$, pelo método radiográfico e de $0,31 \mathrm{~mm}$, avaliando-se os modelos montados em articulador. 
Wood \& Korne (1992) analisaram a natureza dos deslocamentos condilares entre RC e MIC, em 37 estudantes de odontologia, por meio de modelos montados em articulador, do indicador de posição mandibular (IPM) e de registros em cera, das posições consideradas. Avaliou-se também, a reprodutibilidade dos registros no IPM, além da possível variabilidade das distrações e deflexões condilares, em função da montagem dos modelos, segundo eixos de rotação verdadeiros ou estimados. A posição condilar pesquisada em MIC foi sempre inferior àquela de RC e as direções dos deslocamentos foram ântero-inferior, póstero-inferior e diretamente inferior. O deslocamento vertical médio foi de $+1,24 \mathrm{~mm}$ no lado direito e $+1,13 \mathrm{~mm}$, do lado esquerdo. No sentido horizontal, o deslocamento médio foi de $0,32 \mathrm{~mm}$ no lado direito e $+0,31 \mathrm{~mm}$, no esquerdo. Todos os valores médios apresentaram grande variabilidade. Constataram também, grande proximidade entre os eixos de rotação cinemático e estimado, havendo segundo eles, relação entre os valores do IPM, obtidos por meio de modelos montados segundo ambos eixos de rotação condilar. Em decorrência da confiabilidade e da praticidade, recomendam o uso do eixo estimado de rotação para a montagem de modelos ortodônticos, com finalidade de avaliar a posição mandibular, e no emprego dos valores do IPM ao converter para $\mathrm{RC}$, as telerradiografias laterais da face, obtidas em MIC. Finalmente, constataram que os registros dos deslocamentos condilares por meio do IPM são altamente reproduzíveis.

De acordo com Wood \& Elliott (1994), muitos ortodontistas da atualidade têm adotado modelos montados em articulador, como ponto de 
partida para o diagnóstico ortodôntico pois, as montagens em RC podem revelar maloclusões completamente diferentes daquelas encontradas em máxima intercuspidação habitual. Foi avaliada então, entre outros aspectos, a direção do deslize exibido entre RC e MIC. A amostra foi constituída de 39 estudantes de odontologia, sem distúrbios da ATM. Os modelos foram montados em articulador Panadent e os deslocamentos condilares, estudados por meio do indicador de posição condilar. Verificou-se que o tipo prevalecente de deslize entre RC e MIC resultou em deslocamento pósteroinferior dos côndilos, ocorrendo em 63\% da amostra. Em 20\% dos registros, o deslocamento foi ântero-inferior e, em 8\%, foi diretamente inferior. Em 9\% da amostra, os registros de RC localizaram-se abaixo de MIC, caracterizando segundo os autores, erro no registro daquela posição. No sentido horizontal, o deslocamento condilar médio entre as posições avaliadas foi de $-0,26 \mathrm{~mm}$ (distal) e no vertical, foi de $1,2 \mathrm{~mm}$, à partir de RC.

Alexander et al. (1995) avaliaram a existência de posições mandibulares distintas, a reprodutibilidade das posições mandibulares, e a relação côndilo-disco-fossa, por meio de montagens de modelos em articulador e de imagens por ressonância magnética das ATM. A amostra foi constituída por 28 indivíduos do sexo masculino, com idades entre 22 e 35 anos, com relação molar de $\mathrm{Cl} \mathrm{I}$, livres de sintomas perceptíveis de distúrbios articulares. Constatou-se por meio de análise em articulador, que as posições de MIC e RC são reproduzíveis estatísticamente, e que a posição mandibular em MIC é diferente daquela ocupada em RC e RE (posição retruída). Não se observou distinção entre aquelas duas últimas 
posições mencionadas. Em MIC, os côndilos apresentaram-se normalmente, deslocados anterior e inferiormente. Segundo os autores, a concentricidade dos côndilos nas fossas mandibulares foi observada em metade da população e permaneceu consistente nas três posições avaliadas. Tal informação permite suspeitar da impossibilidade de modificar-se a concentricidade condilar, ao manipular-se a mandíbula. Embora a amostra tenha sido selecionada a partir de indivíduos normais, salientou-se que aproximadamente, metade dos côndilos apresentou-se excêntrica. Assim, a avaliação da saúde da ATM, por meio da concentricidade dos côndilos nas fossas, não pode ser apoiada pelos dados obtidos. Observou-se ainda que, 13\% das articulações examinadas apresentaram deslocamento anterior de disco, o que confirma a presença daquela alteração, em população assintomática. Entre os sete indivíduos com deslocamento anterior de disco, dois apresentaram ruídos articulares, assim como 5, com relações discocondilares normais. Desta forma, na ausência de outros sintomas, os ruídos articulares não podem ser tomados como evidência suficiente de distúrbio daquelas estruturas.

Em revista da literatura a respeito da interação entre fatores morfológicos ou funcionais e DTM, McNamara Jr. et al. (1995) encontraram estudos que detectaram, por sua vez, associação relativamente baixa entre fatores oclusais e aquelas alterações, não sendo porém, inexistentes. Aspectos como mordida aberta esquelética anterior, sobressaliências maiores que $6 \mathrm{~mm}$ ou $7 \mathrm{~mm}$, deslizes entre RC e MIC maiores que $4 \mathrm{~mm}$, 
mordida cruzada unilateral e perda de cinco ou mais dentes, caracterizaram os grupos com DTM.

Utt et al. (1995) estudaram o deslocamento condilar entre as posições de RC e MIC, em 107 pacientes aceitos para tratamento no programa de residência em ortodontia das forças armadas dos EUA. A amostra contou com 48 indivíduos do sexo masculino e 59, do feminino, com idades entre 7,75 e 38,17 anos. Dentre aqueles pacientes, 31 apresentaram maloclusão de $\mathrm{Cl}$ I, 72, de $\mathrm{Cl}$ II e 4, de Cl III. Os registros de MIC, RC, do arco facial, do MPI, além de modelos montados em RC no articulador SAM, foram obtidos antes do tratamento ortodôntico, por 4 diferentes ortodontistas. Os autores encontraram discrepância de posição condilar entre RC e MIC, maior que $2 \mathrm{~mm}$, em pelo menos, uma direção do plano sagital, em 19\% dos pacientes. No plano transversal, 15,9\% denotaram discrepância de $0,5 \mathrm{~mm}$ ou mais, entre as duas posições avaliadas. Não foi encontrada correlação entre as discrepâncias condilares e fatores tais como idade, ângulo ANB, sexo ou tipo de maloclusão classificada segundo Angle (1899). Como aqueles fatores não contribuíram para a predição da freqüência, magnitude ou direção das discrepâncias condilares em RC e MIC, os autores (Utt et al., 1995) concluem que os modelos de estudo de todos os pacientes deveriam ser montados em articulador, em RC, com finalidade de diagnóstico.

Gaither et al. (1997) compararam as posições condilares em RC com aquelas de MIC, em 24 adolescentes, antes do tratamento ortodôntico (T1), após o tratamento (T2) e na fase de contenção (T3). Os modelos foram montados em articulador semi-ajustável SAM, com auxílio do arco facial e de 
registros interoclusais de RC. As diferenças de posição condilar entre RC e MIC, foram medidas nos três planos do espaço. Os resultados demonstram que a distância condilar média tridimensional entre $\mathrm{RC}$ e $\mathrm{MIC}$, tende a aumentar da fase pré-tratamento até o período de contenção, especialmente nos côndilos do lado esquerdo. Entretanto, aquela diferença poderia ser resultante não apenas da mudança de postura condilar entre as duas posições estudadas, mas também, da variabilidade intra e interexaminadores. Os autores concluem que seria útil conduzir um estudo similar com maior controle sobre vários aspectos. Um único operador deveria ser responsável pela coleta de todos os registros, pelas montagens dos modelos em articulador e pelas medidas dos modelos no indicador de posição condilar. Também seria importante registrar-se intraoralmente, a posição de MIC.

Milosevic \& Samuels (1998) avaliaram a prevalência de deslocamento mandibular entre RC e MIC e de interferências durante os movimentos funcionais, em pacientes tratados ortodonticamente, com aparelhos fixos em ambas as arcadas, para obtenção de relação incisal de $\mathrm{Cl}$ I. A amostra constituiu-se de 188 indivíduos, sendo 124 (66\%) do sexo feminino e 64 (34\%), do masculino, com média de idade de 17 anos. Os pacientes foram tratados em três instituições de ensino diferentes, por 12 alunos de pósgraduação e por 4 membros dos departamentos de ortodontia, tendo-se empregado 5 tipos diferentes de aparelhos ortodônticos fixos. Os resultados mostram a presença de deslize entre RC e MIC em 18\% dos casos, além de contatos no lado de não trabalho, durante movimento de lateralidade, e 
contatos posteriores durante o movimento protrusivo, em $31 \%$ e $23 \%$ da amostra, respectivamente. As interferências foram significativamente, mais freqüentes nos casos tratados pelos alunos de pós-graduação, comparandose com aqueles tratados pelos membros do departamento. Sobremordidas maiores que $2,4 \mathrm{~mm}$ reduziram de forma significativa, os contatos mediotrusivos e as interferências em dentes posteriores, no movimento protrusivo. Os autores recomendam que os supervisores de clínicas avaliem cuidadosamente, as relações funcionais dos pacientes tratados por estudantes.

Para alguns autores, a discrepância entre RC e MIC constitui desarmonia funcional, podendo contribuir para os distúrbios da ATM. Aquelas discrepâncias seriam decorrentes principalmente, de contatos prematuros em RC. A influencia das mesmas e de outros fatores oclusais sobre os distúrbios temporomandibulares constituem ainda, assunto controverso.

Jarabak (1956) avaliou a possível relação entre interferências oclusais e distúrbio funcional do músculo temporal, por meio de eletromiografia, e se seria possível eliminar a atividade muscular anormal, restabelecendo-se a correta oclusão funcional. A amostra constituiu-se de 22 indivíduos, divididos em três grupos: com oclusão normal e ausência de sintomas de DTM; pacientes tratados ortodonticamente e com estalidos na ATM; com colapso oclusal, acompanhado de estalido ou dor da ATM, além de dor profunda dos músculos posturais da mandíbula. Constatou-se que os distúrbios funcionais da ATM podem ser decorrentes de interferências oclusais dos dentes, pois, 
o espasmo do músculo temporal desaparece quando removidas aquelas interferências e volta a ocorrer, quando reintroduzidas.

Segundo Perry (1956), o papel exercido pelas estruturas proprioceptivas poderia explicar o comportamento dos músculos da mastigação, diante das interferências oclusais. Assim, na presença daquelas interferências, a contração muscular de baixa intensidade seria estimulada por impulsos nervosos, com conseqüente deslocamento e manutenção da mandíbula, em posições afastadas daquelas interferências. Dependendo da severidade das interferências ou do tempo de permanência delas, o processo de proteção descrito, pode transformar-se em condição patológica, culminando com espasmo muscular e dor. Diversos grupos musculares faciais, cranianos e cervicais, especialmente os músculos temporal e pterigóideo lateral, podem apresentar envolvimento doloroso, tendo como origem as maloclusões funcionais. Naquela circunstância, Perry (1956) recomenda o uso de placas oclusais ou desgaste seletivo dos dentes, a fim de restabelecer o equilíbrio oclusal.

Thompson (1956) esclarece que, ante interferências oclusais ou contatos prematuros de certa magnitude, ocorre deslocamento do côndilo. Em conseqüência, os ligamentos disco-condilares tornam-se flácidos, permitindo movimento descoordenado das estruturas da ATM. Segundo o mencionado autor, ao mesmo tempo em que a ATM apresenta capacidade adaptativa e certo grau de tolerância, é também, um tanto precisa no que tange aos complexos movimentos funcionais. Esclarece que o grau de 
tolerância da ATM varia entre os indivíduos e apresenta três casos, ilustrando a relação entre problemas funcionais e padrões oclusais.

Em estudo sobre a possível conexão entre maloclusões morfológicas e funcionais, Ahlgren \& Posselt (1963) analisaram 143 indivíduos, dos quais, 120 constituíram o grupo sem tratamento ortodôntico, e 23, o grupo tratado ortodonticamente. O estudo envolveu a análise funcional do sistema mastigatório, o ajuste oclusal de pacientes tratados ortodonticamente e com interferências oclusais, além do registro eletromiográfico dos músculos masséter, temporal e supra-hióideos. Constatou-se grande incidência de interferências oclusais, tanto nos pacientes tratados (61\%) como nos não tratados ortodonticamente (55\%). Partindo das evidências clínicas e eletromiográficas deste estudo, os autores (Ahlgren \& Posselt, 1963) consideram de grande importância, o exame da oclusão na fase final do tratamento ortodôntico, em busca de interferências oclusais. Para eles, aquelas interferências podem representar o aspecto mais importante da maloclusão, além das alterações estéticas faciais aparentes.

Para Geering (1974), tanto os defensores da escola da "cêntrica justa", como da "liberdade em cêntrica", concordam que os contatos prematuros em RC e as interferências durante os movimentos funcionais estão entre os fatores predisponentes dos distúrbios do sistema mastigatório. O autor estudou então, a possível relação entre aqueles contatos e a dor ou desconforto da ATM, dos músculos e estruturas adjacentes. A amostra foi constituída de 250 indivíduos, dos quais se obtiveram a história clínica e a análise oclusal. Em análise preliminar de 70 
indivíduos, foi encontrado deslocamento lateral médio entre RC e MIC de 1,25mm em 33\% dos indivíduos assintomáticos; de 0,86mm em $54 \%$ dos indivíduos com sintomas de DTM porém, ser dor, e de 1,22mm em $64 \%$ dos indivíduos com sintomas e/ou dor. Os resultados confirmam que os distúrbios musculares independem da magnitude dos deslizes entre RC e MIC. Avaliando-se os 250 indivíduos, observou-se correlação entre deslizes laterais e ântero-posteriores e a ocorrência de dor e/ou sintomas de distúrbios dos sistema estomatognático, principalmente se associados a interferências em balanceio.

Randow et al. (1976) realizaram exame clínico e eletromiográfico em um grupo de 8 indivíduos assintomáticos, que receberam incrustações altas, introduzindo-se experimentalmente, interferências em RC e MIC. Constatouse que, mesmo interferências insignificantes podem afetar a coordenação dos músculos mandibulares, podendo às vezes, implicar em alterações patológicas dos diferentes componentes do sistema mastigatório. As manifestações decorrentes seriam a sensibilidade dentária à percussão, sensibilidade à palpação dos músculos temporal, masséter, pterigóideo lateral e da ATM, tanto no polo lateral como posterior, estalido durante a abertura mandibular e considerável descoordenação muscular durante o fechamento bucal na "nova" posição de MIC. Foi enfatizada então, a necessidade de cuidados, sempre que os tratamentos odontológicos envolvam as superfícies oclusais dos dentes, independentemente da complexidade dos mesmos. 
Ingervall et al. (1980) pesquisaram, entre outros aspectos, as possíveis correlações entre diferentes tipos de interferências oclusais e a presença de sintomas de distúrbios mandibulares. A amostra contou com 389 indivíduos com idades entre 21 e 54 anos, avaliados por meio de questionário e exame clínico. Constatou-se correlação positiva entre interferências em balanceio ou contato único no lado de trabalho e a presença de sintomas subjetivos de distúrbio temporomandibular. O contato único no lado de trabalho correlacionou-se com o travamento, luxação e sons na ATM, assim como os contatos prematuros em RC mostraram correlação com sons da ATM e dor muscular.

Egermark-Eriksson et al. (1983) estudaram a influência de alguns fatores dentários, oclusais e do bruxismo sobre os sintomas de distúrbio mandibular. A amostra foi constituída de 402 crianças de ambos os sexos, divididas em grupos com idades de 7, 11 e 15 anos. Tendo encontrado alta incidência de interferências oclusais nos três grupos avaliados, constatou-se correlação negativa entre aquelas interferências e a dor de cabeça. Observou-se correlação positiva entre deslize entre RC e MIC e sintomas subjetivos de DTM, embora com influência pouco significante. O estalido da ATM correlacionou-se com contato prematuro em RC e com desgastes dentários, indicando possível influência de fatores oclusais sobre a ATM.

Os autores comprovam mais uma vez, neste estudo, a heterogeneidade da etiologia do distúrbio mandibular. Porém, segundo eles, as interferências oclusais parecem ter maior significado no aparecimento de 
distúrbios temporomandibulares em crianças, do que outras anomalias oclusais.

De Laat et al. (1986) investigaram a correlação entre alguns parâmetros oclusais e articulares, e os sinais e sintomas iniciais de DTM. A amostra foi constituída de 121 estudantes de odontologia, com média de idade de 23,4 anos, sendo 71 do sexo masculino e 50, do feminino. Os autores observaram maior freqüência de estalidos da ATM, na presença de cêntrica longa, de contatos prematuros em RC, de interferências em balanceio, e de menor número de dentes. A dor na ATM não mostrou correlação clara com nenhuma das variáveis oclusais, porém, a dor muscular correlacionou-se positivamente com o desgaste dentário e com a sobressaliência anterior. Os autores concluem que, embora haja diversas correlações significantes entre fatores oclusais e sinais e sintomas de DTM, as relações oclusais não podem ser consideradas as responsáveis pela etiologia daquele distúrbio, confirmando a natureza multifatorial do mesmo.

De Boever \& Adriaens (1988) observaram forte correlação positiva entre interferências oclusais e severidade dos sintomas de DTM, em um grupo de 135 pacientes portadores daquele distúrbio, nunca tratados anteriormente.

Arnett \& Tamborello (1990) estudaram a retrusão mandibular progressiva, em 10 indivíduos do sexo feminino, com idades entre 20 e 40 anos. Dentre 5 possibilidades avaliadas como possíveis causas daquela retrusão, são citados o deslocamento anterior dos côndilos e postura mandibular alterada ao início de tratamentos ortodônticos e cirúrgicos. Com 
aqueles procedimentos, haveria então, retorno vagaroso dos côndilos ao eixo terminal. Os autores aventam também, a hipótese de que pequena porcentagem da população feminina jovem, responda adversamente a tratamentos ortodônticos e cirúrgicos normais. Aquela população seria propensa à reabsorção condilar, secundária ao aumento de carga sobre as articulações, normalmente bem tolerado pela população feminina em geral. Aquele grupo parece exigir cuidados ortodôntico-cirúrgicos que minimizem a sobrecarga sobre ATM, evitando-se o uso de elásticos intermaxilares e aparelhos extrabucais.

Os resultados encontrados indicam que o sucesso do tratamento daquelas pacientes depende da correta identificação do processo. Tratamentos bem sucedidos foram alcançados com a coordenação ortodôntica das arcadas, medicação antinflamatória e longo tempo de uso de placa estabilizadora oclusal superior. Os ajustes da placa resultaram em posição centralizada dos côndilos nas respectivas fossas, confirmada por meio de tomografias.

Considerando a etiologia das desordens temporomandibulares um tema controverso e não compreendido inteiramente, Kampe \& Hannerz (1991) re-examinaram indivíduos com idades entre 19 e 21 anos, 5 anos após um primeiro exame. Foram avaliados os sinais e sintomas de distúrbio temporomandibular estabelecendo-se os índices anamnésico e clínico de disfunção, segundo Helkimo (1974). A amostra foi constituída de 37 indivíduos com dentes restaurados em ambas épocas de exame (grupo F), 13 indivíduos com dentes intactos no exame inicial, que receberam 
restaurações no período subsequente (grupo Fl), além de 14 indivíduos com dentaduras intactas em ambos os exames (grupo I).

Observou-se que os indivíduos com restaurações demonstraram grau mais alto e maior frequência de distúrbio temporomandibular que aqueles com dentes intactos.

A maioria dos sintomas foi julgada moderada, porém, os sintomas mais severos foram exibidos pelos indivíduos do grupo $\mathrm{F}$, especialmente pelas mulheres. A maior incidência de parafunção no grupo $F$, associada à maior ocorrência de atrição dos molares inferiores, maior sensibilidade muscular e maior frequência de dor durante os movimentos mandibulares, nos grupos Fl e F, indica maior hiperatividade muscular, em indivíduos com dentes restaurados. A função muscular mostrou-se, por outro lado, mais equilibrada nos indivíduos com dentaduras intactas. Os autores concluem que, embora a etiologia dos distúrbios da ATM seja controversa, os resultados encontrados indicam que as restaurações oclusais teriam possível significância etiológica.

A influência dos contatos prematuros e das interferências oclusais sobre o DTM, foi avaliada indiretamente, por Vallon et al. (1995), ao estudarem o efeito terapêutico do ajuste oclusal, em pacientes com distúrbios temporomandibulares. A amostra foi constituída de 50 pacientes, divididos aleatoriamente em grupo de tratamento $(\mathrm{T})$ e grupo controle (C). Os indivíduos do grupo T foram tratados por meio de ajuste oclusal, com o objetivo de estabelecerem-se contatos bilaterais simultâneos em RC, sem desvio lateral entre RC e MIC; guias pelos caninos ou função de grupo no 
lado de trabalho, sem interferências mediotrusivas durante os movimentos de lateralidade, e sem interferências posteriores, no movimento protrusivo. Os participantes do grupo controle receberam apenas, aconselhamento. Os sintomas subjetivos e os sinais clínicos foram avaliados antes do tratamento, repetindo-se os exames, três e seis meses após a realização do mesmo. No grupo T, observou-se melhora expressiva de todos os sintomas subjetivos considerados aos 3 e 6 meses após ajuste oclusal, porém encontrou-se diferença estatísticamente significante entre os grupos, apenas na avaliação após três meses de ajuste. Constatou-se também, aumento expressivo da freqüência de dor facial no grupo $\mathrm{C}$, resultando em diferença significante entre os dois grupos, na avaliação feita 6 meses após ajuste. Naquele momento, encontrou-se ainda redução da freqüência de dor de cabeça em $36 \%$ dos pacientes do grupo T e em $24 \%$ do grupo C. Vallon et al. (1995) concluem que o ajuste oclusal constitui modalidade de tratamento, de efeito estatísticamente significante a curto prazo, sobre os sintomas de DTM de origem muscular, mostrando-se superior ao aconselhamento.

Arnett et al. (1996a); Arnett et al. (1996b) retomam a preocupação com a retrusão mandibular progressiva, provocada por reabsorção condilar idiopática. Os autores distinguem os processos de remodelação funcional e disfuncional, e esclarecem que fatores como idade, doenças sistêmicas, hormônios, e estresse mecânico podem contribuir para a diminuição da capacidade de remodelação funcional da ATM. Segundo eles, as estruturas articulares parecem ser muito sensíveis à sobrecarga funcional e a resposta tecidual a ela varia, dependendo de fatores do hospedeiro. Para os autores, 
o estresse mecânico é provavelmente, a causa mais freqüente de reabsorção condilar. Entre os fatores mecânicos capazes de iniciar alterações estruturais da ATM, os autores incluem a terapia e a instabilidade oclusais, além da parafunção. Ainda segundo os autores citados, as oclusões instáveis caracterizam-se pela deflecção dos côndilos, durante a intercuspidação dentária. A correção ortodôntica ou cirúrgica das maloclusões, na presença de compressão condilar, pode levar à reabsorção daquela estrutura. Os autores informam também, que as oclusões instáveis que resultam em reabsorção condilar, devem ser estabilizadas para que possa ocorrer o restabelecimento da ATM.

De acordo com Dawson (1996), a oclusão representa um dos mais importantes fatores que afetam a função coordenada dos músculos mastigatórios. Segundo ele, a terapia oclusal tem como objetivo eliminar a deflecção condilar decorrente de contatos entre vertentes de dentes opostos, durante a função mandibular. Acrescenta que o aspecto mais importante para o alívio da dor e desconforto musculares, é o completo assentamento dos côndilos, nas respectivas fossas mandibulares. Naquela circunstância, as articulações permanecem confortáveis, mesmo se firmemente sobrecarregadas. Finalmente informa que, na presença de discrepância entre RC e MIC, a dor decorrente do músculo pterigóideo lateral representa achado clínico comum, podendo ser facilmente confundida com distúrbio intracapsular da ATM.

Luther (1998) acredita que os temas relacionados à função oclusal, à maloclusão e à DTM sejam controversos, devido à qualidade dos estudos 
publicados e muitas vezes, à presunção de que correlações encontradas implicam obrigatoriamente, em causalidade. O autor afirma esperar ainda, pelo "estudo perfeito" que possa avaliar a relação entre maloclusão e DTM, sem a presença de "bias".

A despeito das controvérsias relacionadas com os efeitos da discrepância entre RC e MIC sobre os distúrbios temporomandibulares, as diversas especialidades odontológicas parecem concordar que a RC constitui importante posição de referência, quando realizadas restaurações extensas da oclusão ou no tratamento de pacientes com sinais e sintomas de DTM.

Têm sido propostas diversas técnicas de determinação e registro da relação cêntrica. A desprogramação do sistema neuromuscular parece exercer importante influência no registro acurado daquela posição.

Lucia (1964) desenvolveu um dispositivo em resina acrílica, denominado "Jig", destinado a encaixar-se nos dentes anteriores superiores, mantendo um ou dois contatos com os incisivos centrais inferiores, com conseqüente desoclusão dos dentes posteriores. O "Jig" foi criado com o objetivo de diminuir-se a ação das estruturas proprioceptoras, com resultante relaxamento muscular, permitindo assim o registro da $\mathrm{RC}$, de forma fácil e confiável.

Long (1970) propôs o encaixe de espátula abaixadora de língua, entre os dentes anteriores, no momento do registro da RC, ao mesmo tempo em que se orienta o paciente a fechar e tracionar a mandíbula para trás. A espátula abaixadora de língua deu lugar, posteriormente, aos calibradores 
de Long (Araújo, et al.,1988) e mais recentemente, ao "Pathfinder" (Long \& Buhner, 1992).

Para Calagna et al. (1973), a consistência dos registros de RC pode ser significantemente afetada pelas condições neuromusculares do aparelho mastigatório. Investigou-se então, a consistência dos registros de RC, em pacientes submetidos à desprogramação neuromuscular por meio do miomonitor, do "Jig" anterior usado por 15min, da estimulação oclusal bilateral com rolos de algodão entre os dentes posteriores e do plano de mordida maxilar usado por 24h, com ligeira desoclusão posterior. Os autores mediram também, as discrepâncias entre MIC e as posições de RC registradas segundo os 4 métodos avaliados. A amostra consistiu de 15 indivíduos de ambos os sexos, com idades entre 22 e 49 anos, com dentadura completa, com discrepância visível entre RC e MIC, com história sistêmica e fisiológica normais, e sem dor na ATM ou áreas associadas. Segundo os resultados obtidos, a desprogramação com plano de mordida resultou nos registros mais consistentes e mais posteriormente localizados. A discrepância média entre a $\mathrm{RC}$ registrada segundo aquele método e a posição de MIC foi de $0,7 \mathrm{~mm}$, variando entre $0,28 \mathrm{~mm}$ e $1,17 \mathrm{~mm}$. As discrepâncias médias resultantes do uso do "Jig", do miomonitor, da estimulação oclusal bilateral e do fechamento livre foram $0,34 \mathrm{~mm}, 0,31 \mathrm{~mm}$, $0,32 \mathrm{~mm}$ e $0,10 \mathrm{~mm}$, respectivamente. Os autores afirmam que todos os candidatos à terapia oclusal deveriam usar planos de mordida por um período mínimo de 24h, antes dos registros mandibulares, já que não há 
meio científico que permita a identificação dos pacientes que necessitem de desprogramação neuromuscular.

Dyer (1973) informa que a despeito do procedimento empregado para o registro da relação cêntrica, os diversos métodos são igualmente imprecisos enquanto a articulação temporomandibular for considerada instável. O autor apresenta método para determinar-se a estabilidade das ATM, empregando o "aparelho ortopédico maxilar", em pacientes com sintomas de DTM. A placa mencionada é construída em resina acrílica, sendo estabelecidos contatos cêntricos uniformes e guias anteriores. A placa deve ser ajustada periodicamente, até que se constate estabilidade articular. O autor ensina que as maiores alterações observadas em função do uso da placa desprogramadora, envolvem o deslocamento do eixo terminal de rotação mandibular, à medida em que a ATM se torna mais estável, sendo ainda, impossível prever-se a direção em que o mesmo ocorrerá. Observase também, menor inclinação da guia condilar em relação ao plano áxioorbitário, durante o movimento protrusivo, além da diminuição do deslocamento lateral imediato (movimento de Bennett), no movimento de lateralidade.

Finalmente, Dyer (1973) lamenta que alguns dentistas raramente avaliem a estabilidade da ATM, antes de iniciar procedimentos restauradores, culpando em parte, o ensino propiciado pelas faculdades de odontologia.

Kantor et al. (1973) afirmam que a importância em registrar-se a relação cêntrica da mandíbula é sentida nos diversos campos da 
odontologia, pois a mesma é adotada como posição de referência para os diferentes tipos de restauração oclusal. Compararam-se então, a reprodutibilidade e o padrão espacial dos registros intermaxilares, obtidos pelas técnicas da deglutição ou fechamento livre, da guia da ponta do mento, da guia da ponta do mento associada ao "Jig" anterior e da manipulação bimanual. A amostra constou de 15 indivíduos, com idades entre 21 e 45 anos. Cada registro foi repetido 6 vezes. Dentre as técnicas avaliadas, a da deglutição foi a que revelou maior variabilidade dos registros, colocando em dúvida, a teoria de que o reflexo de deglutição seja um meio fisiológico acurado para determinar-se a RC. Questiona-se assim, a utilização da técnica do fechamento livre ou do Miomonitor. A maior repetibilidade foi alcançada com a técnica de manipulação bimanual da mandíbula, em $85 \%$ da amostra. A técnica que associou a guia da ponta do mento ao "Jig", apresentou registros relativamente menos consistentes. Três dos quatro pacientes, nos quais a manipulação bimanual não foi a mais consistente, apresentaram resultados inconsistentes em geral, a despeito da técnica adotada. Ainda, segundo os autores (Kantor et al., 1973), as posições mais protruídas foram registradas pela técnica do fechamento livre, e as mais retruídas, pela associação entre guia da ponta do mento e "Jig".

Lauritzen (1974) e Dawson (1973) sugeriram dois métodos distintos de manipulação mandibular, a fim de posicionar-se a mandíbula em $\mathrm{RC}$, no momento de seu registro.

Kovaleski \& De Boever (1975) estudaram a influência das placas oclusais sobre a posição mandibular e alívio de sintomas musculares e da 
ATM. Para tanto, empregaram uma amostra constituída de 11 pacientes, sendo dois do sexo masculino e 9, do feminino, com idades entre 14 e 35 anos. Os sintomas observados encontravam-se presentes por períodos entre 5 meses e 10 anos, e nenhum dos participantes havia recebido tratamento prévio por meio de placas oclusais.

Após um mês de uso das referidas placas, constatou-se mudança da postura mandibular, com deslocamento desta em direção ao lado sintomático. Aquele deslocamento parece relacionar-se com o relaxamento observado, da porção posterior do músculo temporal. Encontrou-se ainda, diminuição dos sintomas musculares e da ATM.

Roura \& Clayton (1975) informam que os movimentos bordejantes mandibulares são reproduzíveis e podem ser registrados graficamente, por meio de pantógrafo, em indivíduos com função muscular e articular aparentemente normal. Uma das possíveis causas da ausência de reprodutibilidade dos referidos movimentos, seria o distúrbio da ATM. Os autores observaram os movimentos mandibulares por meio de pantógrafo, em indivíduos com distúrbios da ATM, e os efeitos da terapia com placa oclusal sobre os mesmos. A amostra foi composta por 5 indivíduos com distúrbio da ATM e um, avaliado clinicamente como "normal". Constatou-se que o indivíduo sem sinais e sintomas aparentes de distúrbio da ATM, permitiu a obtenção de registros das posições mandibulares de forma reproduzível, não se repetindo o mesmo em pacientes com sintomas daquela alteração. Observou-se também, que um mês de terapia com placas oclusais resultou no alívio da maioria dos sinais e sintomas de disfunção, 
tanto clínica como eletromiograficamente, embora a remissão completa dos referidos sintomas não se tenha evidenciado. Um mês de terapia com placas oclusais, não foi suficiente para aliviar os sintomas, de forma a permitir registros reproduzíveis das posições mandibulares, em um dos pacientes com distúrbio articular.

Solberg et al. (1975) avaliaram a curto prazo, a efetividade da terapia com placa oclusal, em pacientes com briquismo. A amostra constituiu-se de 8 indivíduos, sendo 6 do sexo feminino e 2, do masculino, com idades entre 22 e 34 anos, que usaram placa oclusal durante o sono, no período em que se desenvolveu o estudo. O referido grupo já havia participado de avaliação anterior, em que se estudou a efetividade dos procedimentos para mudança de comportamento, na redução dos níveis de briquismo. Naquele estudo, constatou-se que os procedimentos considerados apresentaram apenas, efeito transitório, com o retorno aos níveis iniciais de briquismo. No presente estudo, a atividade eletromiográfica do músculo masséter foi registrada em três períodos consecutivos de 10 dias cada um, antes, durante e após a terapia com placa. Observou-se redução imediata da atividade muscular noturna, logo após a inserção das placas, permanecendo baixa, até a remoção das mesmas. Quando interrompido o uso daqueles dispositivos, os valores eletromiográficos retornaram imediatamente, aos níveis encontrados antes do tratamento, em 7 dos 8 pacientes. Segundo os autores, os dados encontrados demonstram claramente, que a terapia com placa envolve redução significante da atividade muscular. 
Crispin et al. (1978), tendo já constatado o sucesso das placas oclusais na eliminação de sintomas de distúrbios da ATM, estudaram o efeito das mesmas e do ajuste oclusal, sobre a reprodutibilidade dos movimentos bordejantes da mandíbula, registrados por meio de pantógrafo. A amostra contou com 26 indivíduos divididos em três grupos, denominados "grupo não reproduzível controle", "grupo reproduzível controle" e "grupo não reproduzível experimental", segundo a capacidade exibida ao início, de reproduzirem-se os movimentos bordejantes da mandíbula, no pantógrafo. Foi observada melhora estatísticamente significante na reprodutibilidade pantográfica, como resultado das terapias oclusais. Eles afirmam ainda, que a resposta à terapia oclusal varia individualmente, devendo adequar-se às necessidades de cada paciente.

De acordo com Ramfjord (1978), tem sido demostrado que a ATM constitui a estrutura mais estável do aparelho mastigatório, apresentando, se tanto, capacidade limitada de adaptação funcional ante alterações da oclusão, em indivíduos adultos. Assim, a oclusão deveria ser reconstruída ou ajustada de forma a acomodar-se às características anatômicas da ATM. Para o autor, a melhor abordagem para orientar a relação maxilomandibular nos procedimentos restauradores, implica na determinação da RC, sendo, para tanto, absolutamente necessário o completo relaxamento dos músculos mandibulares do paciente. Quando encontrada dificuldade em obter-se o relaxamento muscular exigido, o autor recomenda o uso de placa oclusal miorrelaxante e adverte que nenhum ajuste oclusal ou 
reconstrução bucal deve ser iniciado, antes que se alcance o completo relaxamento dos músculos mandibulares.

Beard \& Clayton (1980) estudaram o efeito da terapia com placa oclusal sobre os sintomas de distúrbio das ATM. Foram realizados 486 registros pantográficos, nos 15 pacientes do grupo experimental, num período de 5 meses. Aqueles pacientes usaram placas oclusais até que se constatasse redução dos sintomas de distúrbio da ATM e fossem obtidos registros pantográficos reproduzíveis. Os 5 constituintes do grupo controle foram monitorados por igual período de tempo, sem que tenham recebido qualquer terapia oclusal. Os autores verificaram que a terapia com placas oclusais reduz os sintomas musculares de disfunção da ATM, promovendo função muscular coordenada. Pacientes com características de distúrbio mais acentuadas, ou que apresentaram história mais antiga daquela alteração, exigiram período maior de terapia oclusal para tornarem-se livres da sintomatologia apresentada. Finalmente, foi concluído que, apenas a terapia com placa, é insuficiente para manter a coordenação muscular no tratamento dos distúrbios da ATM, já que todos os pacientes tiveram o retorno dos sintomas musculares, após a remoção das placas oclusais.

Goharian \& Neff (1980) informam que as contenções oclusais terapêuticas, freqüentemente chamadas de "splints" oclusais, placas de mordida, protetores noturnos ou protetores de mordida, podem ser usados para o diagnóstico de fatores etiológicos e para alívio terapêutico dos sintomas da ATM e dor facial. Aquele tipo de aparelho estaria indicado 
então, na correção da relação côndilo-fossa, no alívio do espasmo muscular, no estabelecimento da relação cêntrica mandibular balanceada, modificando-se o efeito das interferências oclusais, interceptando-se o bruxismo e restaurando-se a máxima abertura intermaxilar. Assim, aqueles autores estudaram o efeito das placas oclusais, em pacientes com dor facial ou da ATM, com origem no distúrbio oclusal. A amostra constituiu-se de doze indivíduos do sexo feminino e cinco, do masculino, que apresentaram ao exame clínico, dor muscular $(76,4 \%)$, dor na ATM (70,5\%), desvio mandibular $(88,2 \%)$, briquismo ou mordida supertensa (47\%) e estalido (29,4\%). O exame clínico revelou na maioria dos pacientes, a presença de interferências oclusais em um dos lados da arcada e conseqüente desvio mandibular para o lado oposto. Nos pacientes com desvio mandibular a partir de RC, observou-se envolvimento do pterigóideo lateral $(77,7 \%)$ e medial no lado do contato prematuro, e dos músculos masséter e temporal, no lado oposto. Os indivíduos usaram placas oclusais dia e noite, por um período que variou de três semanas a um ano. Os autores (Goharian \& Neff,1980) constataram que $88 \%$ dos músculos envolvidos apresentaram melhora, assim como $84 \%$ das articulações temporomandibulares responderam favoravelmente ao uso das mesmas.

Roth \& Rolfs (1981) afirma que qualquer registro de RC, obtido sem estabilização prévia da mandíbula por meio de placas oclusais, está sujeito a críticas. O autor acredita ser possível estabilizar-se a posição mandibular com o uso das referidas placas e registrar-se a RC de forma que a mesma 
se repita em registros subsequentes, realizados em intervalos de dias, meses ou anos, em pacientes após o período de crescimento, e que não apresentem alterações degenerativas das articulações. Afirma também, que mesmo os pacientes assintomáticos submetidos ao uso das placas oclusais, reposicionam ligeiramente os côndilos, comparando-se os registros de RC obtidos antes e após o uso daqueles dispositivos. Diz ainda, o referido autor, que se requer um intervalo de tempo para eliminarem-se a tensão muscular, a alteração de postura da mandíbula e o excesso de fluido do interior das cápsulas articulares. Uma vez estabilizada a posição mandibular com o uso das placas oclusais, diferentes boas técnicas de registro da RC revelam posições cêntricas idênticas dos côndilos mandibulares.

Capp \& Clayton (1985a) compararam dois métodos adotados com freqüência, no registro da posição de $\mathrm{RC}$, por meio de aparelho experimental. A análise foi feita na região oclusal, avaliando-se o primeiro ponto de contato dentário. A amostra consistiu de um paciente, de quem foi obtido um par de modelos, construiu-se o "Jig" e foram realizados 20 registros de $\mathrm{RC}$, sendo 10 com a técnica que associou o "Jig" anterior com a guia da ponta do mento e as outras 10, com a técnica de Dawson. Foram feitas 20 montagens do mesmo par de modelos e marcado, em cada uma delas, o primeiro ponto de contato oclusal. Os autores constataram que o método do "Jig" foi o mais consistente nos três planos do espaço, produzindo em média, contatos dentários $0,92 \mathrm{~mm}$ mais posteriores, 0,088mm mais superiores e $0,015 \mathrm{~mm}$ mais à esquerda que o método de 
Dawson. Com a técnica do "Jig", o contato inicial ocorreu nos molares, e na técnica bimanual, nos premolares.

Dando continuidade a estudo anterior, Capp \& Clayton (1985b) comparam novamente, as posições produzidas pela técnicas de manipulação bimanual e do anteparo oclusal anterior, além de analisar os traçados pantográficos feitos ao início e final do estudo. A amostra constituiu-se de um grupo experimental de 6 indivíduos, com diagnóstico clínico de distúrbio da ATM e de um grupo controle, com 2 indivíduos sem história ou sinais clínicos daquela alteração. Os indivíduos do grupo experimental usaram placa oclusal 24h diárias, por um período de 60 dias, retirando-a apenas, nas refeições. Os resultados demonstram que os registros de RC são mais consistentes nos indivíduos do grupo controle, que não apresentam disfunção da ATM. Em alguns indivíduos do grupo experimental, houve melhora na consistência dos registros com o uso mais prolongado da placa oclusal. A manipulação bimanual não produziu posições mais consistentes quando comparada com a técnica do anteparo oclusal anterior, em ambos os grupos. No grupo controle, a técnica do anteparo resultou em contatos oclusais mais posteriores e superiores. Em função dos resultados obtidos os autores concluem ser importante eliminar-se a disfunção e alcançarem-se relações maxilomandibulares estáveis, antes de iniciados os ajustes oclusais ou restaurações. Os referidos ajustes, na presença de distúrbio da ATM, poderiam resultar em redução oclusal errônea, já que as interferências encontradas naquela situação são diferentes das observadas após a eliminação dos sinais e sintomas. O uso 
da placa resultou em relaxamento da musculatura e permitiu a localização das interferências previamente escondidas pelo sistema neuromuscular. Finalmente, os autores afirmam que a manipulação bimanual não pôde localizar relações mandibulares estáveis, no grupo experimental.

Hobo \& Iwata (1985) avaliaram três diferentes técnicas de localização condilar e registraram a quantidade de deslocamento dos côndilos, nos três planos do espaço, por meio de um sistema eletrônico. As técnicas adotadas foram a do fechamento não guiado, da guia da ponta do mento e da manipulação bimanual. A amostra foi constituída por 10 indivíduos adultos, com idades entre 21 e 32 anos, com dentaduras completas, mínimas restaurações dentárias, relações maxilo-mandibulares ortognáticas e sem sinais e sintomas de distúrbios das articulações temporomandibulares. Antes de realizadas as medições, os indivíduos tiveram um condicionamento neuromuscular com "Jig" anterior usado por 20 minutos. Os deslocamentos condilares máximos registrados pelas três técnicas estudadas variaram aproximadamente, entre $0,2 \mathrm{~mm}$ e $0,3 \mathrm{~mm}$. Segundo os autores, a técnica de manipulação bimanual mostrou a reprodutibilidade mais consistente, recomendando-a para o registro da RC. Para eles, o deslocamento condilar mínimo observado naquela técnica indica a existência da cêntrica justa ("point centric"). As posições condilares obtidas pelas técnicas de manipulação bimanual e de fechamento não guiado foram similares nos sentidos ântero-posterior e súpero-inferior, porém esta última apresentou apreciável deslocamento lateral. A técnica da guia da ponta do mento localizou os côndilos mais posteriormente, inferiormente e para o lado 
direito, não sendo portanto, recomendável, já que o deslocamento posterior dos côndilos pode resultar em danos à zona bilaminar e deslocamentos inferiores podem implicar em discrepâncias oclusais.

Schweikert (1985) afirma que a obtenção do registro da RC depende do estado funcional do sistema neuromuscular, do grau de flacidez dos ligamentos capsulares, da habilidade do dentista e do paciente em alcançarse a referida posição, e do método selecionado para registrá-la. O autor salienta que, pelo fato de os músculos serem um importante fator no registro da relação cêntrica, é essencial que os mesmos se encontrem em estado de harmonia funcional, além de completamente relaxados. É mencionada a existência de procedimentos variados para alcançar-se aquele relaxamento, destacando o ajuste oclusal e o uso de placas de mordida.

Araújo et al. (1988) compararam os registros de RC obtidos com o uso do "Jig" de Lucia e dos calibradores de Long. A amostra foi constituída por 15 pacientes com dentadura íntegra até segundos molares, no mínimo, ausência de trabalhos protéticos e sem sinais de DTM. Foram obtidos três modelos de cada paciente, sendo um superior e dois inferiores, montados em articulador Whip-Mix, empregando-se os registros obtidos segundo as duas técnicas estudadas. Os autores encontraram resultados semelhantes em relação aos parâmetros de comparação adotados, e recomendam o dispositivo de Long, por ser um método mais simples e rápido que o do "Jig". Salientam porém, que os calibradores demandam experiência e domínio da manipulação mandibular em RC. 
Segundo Dupas et al. (1990), as manipulações mandibulares exigem grande destreza manual dos dentistas, podendo resultar em erros substanciais. Afirmam também, que para alcançar-se a relação cêntrica, com rotação condilar pura, é exigido relaxamento muscular e consideram o "Jig" de Lucia, instrumento direto, eficiente e lógico para o registro da posição de $\mathrm{RC}$.

De acordo com Weinberg (1991), pesquisas indicam que a suspensão do côndilo da fossa se faz por mecanismo muscular e não por meio dos ligamentos. Variações no tono muscular influenciam a posição e função condilares normais, assim como a propriocepção dos músculos, tendões, membrana periodontal e ATM, influenciam a programação muscular para a MIC. Explicando os meios de desprogramação muscular existentes, aquele autor informa haver mecanismos desprogramadores a curto e a longo prazo. Os de curto prazo usualmente recomendados, incluem a solicitação para que o paciente coloque a ponta da língua na região posterior do palato, a manipulação bimanual, o uso de anteparos anteriores como o "Jig" de Lucia ou os calibradores de Long. Já, a desprogramação a longo prazo é obtida com o uso de placa de mordida, por um período de 24 horas, sendo removida apenas, durante as refeições. Para Weinberg (1991), os procedimentos descondicionadores a curto prazo, são fracos e ineficientes para superarem o fechamento habitual da mandíbula. Recomenda-se então, o uso das placas de mordida, sempre que indicados procedimentos para correção de contatos deflectivos em RC. 
Segundo Kinderknecht et al. (1992), de 40\% a 50\% dos pacientes com DTM apresentam sensibilidade muscular sub-clínica. Contenção, fadiga e espasmos musculares, alterações do comprimento muscular em repouso, além de padrões protetores do engrama neuromuscular, afetam a habilidade do clínico e do paciente de obterem transferência acurada dos registros, a despeito dos tipos específicos de materiais adotados ou das filosofias seguidas. Avaliaram então, os possíveis efeitos do desprogramador anterior descrito por Okeson (1989), em 20 indivíduos com idades entre 18 e 41 anos, sem sinais e sintomas de distúrbio interno da ATM. Foram construídos modelos superiores e inferiores e tomados os primeiros registros de RC (RC1). Após $30 \mathrm{~min}$ de uso do desprogramador, obteve-se o segundo registro (RC2) e após 12 horas ininterruptas de uso do mesmo, realizou-se o terceiro registro (RC3). Por meio do axiógrafo computadorizado SAM e do registro RC3, testou-se a repetibilidade da posição de relação cêntrica. Foi constatado que a posição do eixo transversal de rotação da mandíbula mostra alguma variação, em indivíduos saudáveis, quando os dentes são encaixados repetidas vezes no mesmo registro de RC. Eles citam alguns componentes biológicos que poderiam influenciar as estruturas da ATM tais como o fluido articular, a elasticidade do conjunto côndilo-disco e o espaço amortecedor de 0,20 a 0,30mm, essencial para a manutenção das ATM saudáveis. Comparando-se os registros RC2 e RC3, observa-se que em $53 \%$ da amostra, os deslocamentos do eixo de rotação em RC2 foram maiores que em RC3, sendo muito menores neste último, em 63\% dos indivíduos. Embora tenham ocorrido modificações de posição condilar 
estatísticamente significantes entre RC2 e RC3, os autores acreditam que as mesmas não apresentem significado clínico, pois, em 18 dos 19 indivíduos avaliados, mostraram-se menores que $0,5 \mathrm{~mm}$, em RC3. Finalmente, os autores concluem que os procedimentos de desprogramação rotineiros, aplicados em pacientes saudáveis, antes da obtenção dos registros das posições mandibulares, não parecem justificáveis.

Como aparelhos de relaxamento muscular têm sido adotados no tratamento de pacientes com dor-disfunção miofascial, Carlson et al. (1993) estudaram o efeito de dois tipos de aparelhos de relaxamento muscular e de um placebo (rolos de algodão entre os dentes), na atividade eletromiográfica dos músculos masséter e temporal anterior. A amostra constituiu-se de doze mulheres com dor-disfunção miofascial, com média de idade de 38 anos. Um dos aparelhos de relaxamento muscular foi construído em RC, obedecendose o protocolo descrito por Okeson (1989). O outro, denominado "neuromuscular orthotic", consiste numa versão do aparelho já mencionado, construído a partir da posição tridimensional mandibular, estabelecida quando os músculos se encontram no estado de mínima atividade eletromiográfica. Não houve diferença entre os dois aparelhos de relaxamento porém, os resultados demonstram diferença estatísticamente significante entre os tratamentos com os dois aparelhos de relaxamento e aquele realizado com rolo de algodão (placebo). O tratamento com rolo de algodão mostrou de forma consistente, valores médios mais altos de atividade eletromiográfica. Os autores concluem que o presente estudo não 
corrobora a crença de que medidas da atividade eletromiográfica ajudariam a construir melhores aparelhos interoclusais.

Neff (1995) define trauma oclusal como o efeito criado pelo contato entre duas superfícies oclusais opostas, antes que qualquer outro tecido do sistema esteja em posição normal. O autor esclarece que todo o sistema articular pode ser afetado por aquele tipo de trauma, incluindo as ATM, os dentes e o sistema neuromuscular. Podem ocorrer em conseqüência do mesmo, desgaste e fratura dentários, espessamento do periodonto, inflamação ou necrose pulpar, contração e necrose muscular inflamatória, deslocamento dos ligamentos temporomandibulares, inflamação e necrose da área retrodiscal. O distúrbio muscular mencionado pode envolver a contração daquele tecido, com conseqüente contração vascular, possível inflamação, alteração química e diminuição do oxigênio dos tecidos, alteração da produção de energia, enfraquecimento e finalmente, a necrose dos mesmos. O autor salienta que o sucesso de qualquer tratamento, incluindo endodontia, periodontia, cirurgia ortognática, ortodontia ou prótese, depende que se estabeleçam contatos uniformes por toda a arcada, sem contatos prematuros. Recomenda então, o uso de placas desprogramadoras para o diagnóstico inicial e diferencial entre a oclusão traumática, definida por um único contato dentário, e a discrepância oclusal múltipla.

Em abrangentes considerações sobre as placas oclusais, Nelson (1995) informa que as mesmas têm sido indicadas desde o início do século, para o controle ou tratamento do bruxismo, do trauma oclusal e de vários tipos de distúrbios temporomandibulares. Cita Greene (1988), ao afirmar que 
a placa oclusal corretamente aplicada pode reduzir o bruxismo noturno, modificar o comportamento neuromuscular, relaxar músculos doloridos, alterar a carga articular e diminuir a dor orofacial, por meio de várias ações físicas e efeitos placebo. Nelson (1995) apresenta uma classificação geral e descreve diversos tipos de placas oclusais. Segundo o ele, as placas com recobrimento oclusal completo podem ou não ser classificadas como estabilizadoras. Estas últimas resistem às alterações da oclusão devendo apresentar as seguintes características:

- Recobrir todos os dentes de uma das arcadas e prover contato oclusal não traumático de todos os dentes da arcada oposta, que exibam potencial de erupção primária ou secundária, inclusive dos terceiros molares.

- O material para a construção da placa deve ser de manuseio conveniente, estável dimensional e termicamente, além de resistir às forças parafuncionais.

- A placa não deve ditar o fechamento mandibular em posições protrusiva, lateral ou retrusiva, evitando-se a acomodação mandibular numa nova posição. Para o autor, uma das principais vantagens da placa estabilizadora maxilar indicada por Ramfjord \& Ash (1984), apoia-se no conservantismo e na reversibilidade da terapia. Apresenta como desvantagens, o tempo, o custo e a habilidade profissionais necessários para o ajuste correto da placa, além de problemas estéticos e fonéticos. Nelson (1995) indica as placas estabilizadoras com o fim de evitarem-se possíveis danos gerados pelo bruxismo, tais como atrição, fratura, mobilidade e/ou dor dentárias; dor, artrite traumática ou remodelação 
degenerativa da ATM e dor, descoordenação ou espasmo musculares. A placa diminui o bruxismo em alguns pacientes, enquanto que em outros, o mesmo mantém-se agressivo. Neste último caso, a placa redistribui as cargas traumáticas, controlando seus efeitos. No tratamento de diversos tipos de distúrbios da ATM, as placas são freqüentemente recomendadas como primeira linha de tratamento. A eliminação temporária das interferências oclusais, por meio das placas, pode ajudar a estabilizar condições dolorosas e normalizar os movimentos mandibulares. Aqueles dispositivos podem produzir ainda, efeito biomecânico favorável sobre a mandíbula, reduzindo o trauma e promovendo a reparação da ATM, com o tempo. Finalmente, 0 autor indica as placas estabilizadoras para 0 relaxamento muscular, a fim de permitir o registro apropriado da $\mathrm{RC}$, com finalidade de diagnóstico.

Contin (1997) comparou a reposição mandibular de MIC para RC, após o uso do "Jig" de Lucia e de placa desprogramadora, em dois grupos de pacientes do sexo feminino, com idades variando entre 21 e 38 anos. 0 grupo I foi composto por 10 indivíduos totalmente dentados, sem sintomatologia de DTM. O grupo II, foi formado por 10 pacientes totalmente dentados, com dor miofascial e sem ruídos articulares. Os registros de RC foram realizados após 3h de uso do "Jig" e após 30 dias de uso contínuo da placa desprogramadora, que pode ser retirada apenas para as refeições. Os resultados demonstram que, nos pacientes assintomáticos, apenas o uso do "Jig" foi suficiente para levar a mandíbula para sua posição de eixo terminal de rotação. Nos pacientes com dor miofascial, aquele eixo de rotação só foi 
alcançado após uso da placa desprogramadora. O deslocamento final entre RC e MIC foi de 3,25mm no grupo sintomático e de $1,4 \mathrm{~mm}$, nos pacientes assintomáticos.

De acordo com Hoyano et al. (1997), a placa desprogramadora parece influenciar a propriocepção da membrana periodontal e descondicionar o padrão habitual da função muscular, com conseqüente equilíbrio desta. Estes autores (Hoyano et al., 1997) estudaram então, os efeitos da placa oclusal sobre os movimentos mandibulares. A amostra foi constituída por doze adultos jovens, sendo 7 do sexo masculino e 5 , do feminino, com média de idade de 24,4 anos. Os indivíduos foram selecionados ao acaso, entre estudantes e funcionários da Universidade de Kyushu. Em exame clínico inicial, todos apresentaram dentadura completa, com exceção dos terceiros molares e oclusão de Cl I de Angle (1899), não havendo história de tratamento ortodôntico nem sintomas de DTM. Os movimentos mandibulares foram medidos por meio de um sistema tridimensional de análise do movimento mandibular, antes e após $24 \mathrm{~h}$ de uso da placa oclusal, mantida em posição, inclusive nas refeições. Os ajustes da placa foram feitos por um único operador, estabelecendo-se suaves impressões das cúspides vestibulares e das bordas incisais inferiores na placa, além de guias pelos caninos e dentes anteriores. A análise do ciclo mastigatório foi feita em três fases distintas: de abertura, fechamento e de oclusão. Verificou-se que a duração do ciclo mastigatório completo foi a mesma, antes e após o uso da placa. Entretanto, a distribuição das diferentes fases foi influenciada pelo uso daquele 
dispositivo, diminuindo de forma significante, a duração da oclusão. A amplitude da abertura vertical manteve-se a mesma, havendo porém, diminuição estatisticamente significante do deslocamento lateral para o lado de não trabalho, gerando assim, um padrão de abertura mandibular predominantemente vertical. Os autores especulam se a ação da placa seria sobre os músculos elevadores ou abaixadores da mandíbula. Parece haver redução da retroalimentação negativa dos músculos elevadores, durante a fase de abertura mandibular, sendo necessários porém, estudos complementares. Os autores concluem que as características motoras do sistema mastigatório alteram-se imediatamente após o início do uso da placa oclusal. 


\section{PROPOSIÇÃO}

Considerando-se a importância do diagnóstico, planejamento e finalização dos tratamentos ortodônticos em RC, para o equilíbrio funcional do sistema estomatognático, são aqui, consideradas as seguintes proposições:

3.1- Definirem-se os deslocamentos dos côndilos dos lados direito e esquerdo, entre as posições mandibulares de RC e MIC, nos planos vertical, horizontal e transversal, nos grupos: Experimental (pósdesprogramação) e Controle (sem-desprogramação).

3.2- Verificarem-se as possíveis diferenças entre os dados dos grupos Experimental e Controle, relativos aos deslocamentos condilares avaliados entre RC e MIC.

3.3- Identificarem-se as correlação entre:

3.3.1- Deslocamento condilar e tempo de uso das placas desprogramadoras.

3.3.2- Deslocamento condilar e estágio de maturidade esquelética.

3.3.3- Deslocamento condilar e idade cronológica 
3.4- Avaliarem-se nos grupos Experimental e Controle, possíveis diferenças entre os lados direito e esquerdo, dos deslocamentos condilares entre RC e MIC.

3.5- Compararem-se nos grupos Experimental e Controle, os deslocamentos condilares entre RC e MIC, dos indivíduos do sexo masculino, com os do sexo feminino. 


\section{CASUÍSTICA - MATERIAL E MÉTODO}

\subsection{Casuística}

A amostra foi constituída por dois diferentes grupos, o grupo Experimental e o Controle. O grupo Experimental contou com 22 indivíduos distribuídos uniformemente entre os sexos, e o grupo Controle constituiu-se de 23 indivíduos, sendo 10 do sexo masculino e 13, do feminino. As idades, no grupo Experimental, variaram entre 11a2m e 16a9m, com média de 14a8m. No grupo Controle, as idades ficaram entre 14a9m e 19a8m, com média de 16a8m.

Todos os participantes da amostra foram selecionados entre os pacientes inscritos para tratamento corretivo, nos cursos de pós-graduação em Odontologia, área de concentração em Ortodontia, da FOUSP, por meio de anamnese e exame clínico. Os modelos das fichas empregadas naqueles dois exames constam do Apêndice.

Foram estabelecidas como critérios de inclusão para ambos os grupos, as seguintes características: presença de dentadura permanente completa até segundos molares, maloclusão de $\mathrm{Cl}$ II de Angle (1899) identificada nas relações oclusais entre molares e/ou caninos, além de 
ausência dos seguintes sinais e/ou sintomas clínicos de distúrbio temporomandibular: dores articular ou muscular espontâneas e/ou durante os movimentos mandibulares, dor à palpação nas ATM, limitação de abertura bucal (abertura máxima menor que 40mm) e travamento ou luxação mandibulares.

Os participantes do grupo Experimental não possuem documento de consentimento esclarecido pois, participaram deste estudo num período em que os Comitês de Ética em Pesquisa não se encontravam ainda, estruturados. Já, para os pacientes do grupo Controle, foram respeitados os critérios adotados pelo Comitê de Ética em Pesquisa, agora existente, pois, participaram mais recentemente, deste trabalho. Esses pacientes concordaram com o termo de consentimento esclarecido, aceitando também, participar das etapas seguintes deste estudo. O referido documento é apresentado no Apêndice.

\section{2- Material e Método}

\subsubsection{Modelos de gesso}

Foram obtidos dois pares de modelos de gesso de cada paciente do grupo Experimental, sendo o primeiro ao início do estudo, e o segundo, após o uso da placa oclusal desprogramadora. No grupo Controle, obteve-se apenas um par de modelos de gesso, ao início do estudo. Para tanto, foram feitas moldagens das arcadas superior e inferior, com hidrocolóide 
irreversível "Jelprint" ${ }^{1}$ e moldeiras metálicas tipo Vernes. Houve o cuidado de não perfurá-las com as pontas das cúspides ou com as bordas incisais dos dentes, prevenindo-se contra a existência de bolhas. Os modelos foram vazados com gesso pedra Durone ${ }^{2}$, na cor verde, na proporção entre pó e água, de $100 \mathrm{gr} / 19 \mathrm{ml}$ e espatulados a vácuo por 40s.

Os excessos de gesso dos modelos foram removidos com auxílio de máquina de recortar e de estilete. Os modelos foram então, preparados segundo a técnica do "modelo partido" de Lauritzen (1974).

\subsubsection{Registro da máxima intercuspidação habitual (MIC)}

A posição de MIC, considerada a posição habitual de máximo contato dentário, foi registrada ao início do estudo, antes da montagem dos primeiros modelos em articulador, em ambos os grupos.

O registro foi obtido em cera rosa Moyco extra-dura ${ }^{3}$, preparada com duas espessuras, e recortada com tesoura, respeitando-se a forma e as dimensões da arcada dentária superior. Depois de plastificada em água a $58^{\circ} \mathrm{C}$ por 1 minuto, a lâmina de cera foi adaptada à arcada dentária superior e o paciente instruído a ocluir totalmente os dentes, com força, provocando perfurações no registro. Foram eliminados todos os excessos vestibulares de cera, a fim de visualizar-se o completo encaixe dos dentes no registro, tanto intrabucalmente como nos modelos de gesso. Foram também, desbastadas com estilete, as áreas do registro de cera, em contato com as

1 Jelprint- Dentsply Indústria e Comércio Ltda- Petrópolis- Rj.

2 Durone- Dentsply Indústria e Comércio Ltda.- São Paulo- SP.

3 Moyco Beauty Pink Wax- Moyco Industries- Philadelphia- PA. 
regiões gengivais dos modelos de gesso, que poderiam impedir o perfeito encaixe oclusal do mesmo.

\subsubsection{Registros da relação cêntrica (RC)}

Todos os indivíduos tiveram registrada a "relação cêntrica" inicial (tentativa de obtenção da posição mais ântero-superior possível dos côndilos na fossa), em cera Delar Azul ${ }^{4}$, para a montagem dos primeiros modelos de gesso, em articulador. Estes modelos destinaram-se à construção das placas desprogramadoras superiores do grupo Experimental, e à avaliação do deslocamento condilar entre RC e MIC, no grupo Controle. No grupo Experimental, novos registros de RC foram obtidos após períodos individuais de uso das placas desprogramadoras, a fim de medir-se o referido deslocamento condilar, após o relaxamento muscular.

A posição de "RC" foi alcançada manipulando-se a mandíbula segundo Dawson (1974), até que a mesma demonstrasse, tanto quanto possível, ausência de resistência à movimentação e aparente movimento de rotação condilar. O registro de RC propriamente dito, foi efetuado em duas etapas, de acordo com a técnica "Power Centric" de Roth (1993) apud Wood et al. (1994) modificada, e descrita a seguir:

Numa primeira etapa, preparou-se um bloco com quatro espessuras de cera, com largura correspondente à distância inter-caninos e profundidade definida em função da sobressaliência exibida pelos indivíduos. O bloco de cera foi aquecido em água a $58^{\circ} \mathrm{C}$ por um minuto no 
mínimo, até que ficasse suficientemente plástico para, em seguida, ser adaptado sobre os incisivos e caninos superiores. Neste momento, a mandíbula foi manipulada em RC segundo Dawson (1974), e elevada vagarosamente, permitindo que os incisivos inferiores penetrassem na face inferior do bloco de cera plastificado e se observasse um espaço remanescente de dois milímetros entre as cúspides superiores e inferiores mais extruídas. Durante esta etapa, não se permitiu qualquer contato entre cúspides opostas.

A cera foi resfriada com jato de ar, por alguns segundos, e em seguida o paciente abriu vagarosamente a boca. Manteve-se a aplicação do jato de ar, até que o bloco de cera se desprendesse dos dentes, sem qualquer pressão manual, evitando-se distorções do registro. Este foi então, lavado em água corrente e mergulhado imediatamente em água gelada.

As edentações superiores e inferiores no registro, foram desbastadas com estilete afiado, sob água corrente, até que restassem impressões suaves, porém nítidas, das bordas dos dentes anteriores de ambas as arcadas, além de eliminadas possíveis interferências da cera, em áreas gengivais dos modelos.

Preparou-se então, uma segunda porção de cera, com largura correspondente à dimensão transversal da arcada superior, na região de segundos premolares e primeiros molares, com duas espessuras de cera e profundidade aproximada de $6 \mathrm{~mm}$. Após plastificação em água a $58^{\circ} \mathrm{C}$, por um mínimo de 1 min, esta segunda porção foi justaposta à arcada dentária superior, na região correspondente. Em seguida, o primeiro registro foi 
readaptado nos incisivos superiores, a mandíbula foi manipulada novamente segundo Dawson (1974), e elevada até alcançarem-se os respectivos encaixes dos incisivos inferiores, nas edentações obtidas na primeira etapa. Criaram-se assim, edentações dos dentes posteriores na nova porção de cera. Esta foi resfriada com jato de ar, até soltar-se espontaneamente dos dentes, sendo então, lavada e mergulhada em água gelada.

Os excessos de cera foram removidos com estilete, de forma a serem expostas as faces vestibulares dos dentes posteriores, permitindo a verificação do completo assentamento dos dentes no registro de cera e a comprovação do perfeito encaixe deste, nos modelos de gesso. Registrou-se assim, a "relação cêntrica inicial" nos grupos Experimental e Controle e a relação cêntrica final, no grupo Experimental, após o uso das placas desprogramadoras.

\subsubsection{Montagem dos modelos em articulador}

Os diversos pares de modelos de gesso foram montados em articulador semi-ajustável Panadent ${ }^{5}$, com o auxílio do respectivo arco facial e dos registros de relação cêntrica, seguindo-se as normas descritas no manual de instrução, fornecido pelo fabricante (BASIC, 1985).

A fixação dos modelos no articulador foi feita com gesso Mounting Stone ${ }^{6}$, acondicionado em envelopes individuais. A proporção entre pó e água foi de $70 \mathrm{gr} / 20 \mathrm{ml}$, e a espatulação a vácuo durou $40 \mathrm{~s}$.

\subsubsection{Desprogramação neuromuscular no grupo Experimental}


A desprogramação neuromuscular foi obtida com o uso de placa oclusal miorrelaxante, construída com resina ativada termicamente, e adaptada à arcada dentária superior. A placa foi ajustada de acordo com os seguintes critérios ensinados por Roth \& Rolfs (1981):

- Adaptar-se convenientemente, em todos os dentes superiores irrompidos, mantendo-se estável.

- Superfície oclusal plana e polida, a fim de evitarem-se estímulos que interferissem com a desprogramação neuromuscular ou reprogramassem a mandíbula numa segunda falsa posição.

- Todas as peças dentárias da arcada oposta, exibindo pelo menos, um contato puntiforme e de mesma intensidade na superfície da placa.

- Construção de guias suaves, pelos incisivos e caninos, a fim de garantir a liberdade de deslocamento mandibular durante os movimentos protrusivo, de lateralidade direita e esquerda, sem a ocorrência de interferências oclusais.

- Espessura da placa de aproximadamente $2 \mathrm{~mm}$, no setor posterior.

Os pacientes foram instruídos a usar as placas 24 horas por dia, devendo retirá-las apenas para higienização, até que se alcançasse a desprogramação neuromuscular. O tempo total de uso das mesmas variou entre os indivíduos, desde um período mínimo de 4 meses e 23 dias, e máximo de 11 meses e 28 dias. O tempo médio de uso foi de 7 meses e 22 dias.

No período inicial de desprogramação, a placa foi reajustada semanalmente, restabelecendo-se e reequilibrando-se os pontos de contato 
oclusais, as guias pelos incisivos e caninos, e eliminando-se quaisquer interferências durante os movimentos funcionais. Quando as mudanças de posição mandibular tornaram-se menos evidentes, os ajustes passaram a ser quinzenais e, finalmente, a cada três semanas. As placas foram ajustadas até que se evidenciasse a completa desprogramação neuromuscular, julgada presente, quando observados os três critérios seguintes:

- Facilidade de manipulação mandibular

- Estabilidade mandibular

- Repetibilidade de três registros consecutivos de RC, obtidos com intervalo de uma semana entre eles.

Quando confirmada a desprogramação neuromuscular, foram obtidos os segundos pares de modelos de gesso do grupo Experimental. Os novos pares foram montados em articulador, empregando-se o terceiro e mais recente registro de $\mathrm{RC}$. 
4.2.6. Determinação dos deslocamentos condilares entre RC e MIC

De posse dos registros de RC e MIC, foram também registradas as posições condilares por meio do Indicador de Posição Condilar Panadent $(\mathrm{IPC})^{7}$, nos grupos Experimental e Controle.

Aquele instrumento é constituído por três blocos metálicos, sendo que dois deles se encaixam no articulador, substituindo as guias condilares direita e esquerda, e o terceiro se adapta centralizado no braço horizontal do corpo inferior do articulador, na região da linha média. Os dois primeiros blocos cursionam lateralmente, guiados por um eixo central, e suas faces externas relacionam-se com os côndilos metálicos do articulador.

Gráficos milimetrados ${ }^{8}$ impressos em papel autocolante foram adaptados às superfícies dos três blocos descritos. Naqueles gráficos foram registradas as posições de RC e MIC, o que possibilitou a medição do deslocamento entre ambas posições. Inicialmente, registrou-se a posição de RC obedecendo-se à seqüência adiante descrita:

Os componentes do IPC foram adaptados no articulador, os modelos foram fixados aos respectivos braços superior e inferior, sendo então relacionados por meio do registro de RC. Mantendo-se a correta adaptação dos elementos mencionados com uma das mãos, deslocou-se lateralmente com a outra mão, um dos blocos laterais, até que este tocasse no côndilo correspondente, com o papel articular de cor preta ${ }^{9}$ interposto entre este e a superfície do gráfico. Demarcou-se assim, um ponto naquele gráfico, correspondente à posição de relação cêntrica. A operação foi repetida no lado oposto.

7 CPI- Panadent Corporation- Grand Terrace- CA.

8 CPI Graph Papers- Panadent Corporation- Grand Terrace- CA.

9 Accu-Film- Parkell- Farmingdale - NY. 
Numa terceira etapa, mantendo ainda pressão sobre o conjunto, demarcou-se o gráfico da linha média, com pequena perfuração produzida pelo pino central do corpo superior do IPC, quando pressionado para baixo.

Registrou-se assim, a posição de RC, nos três planos do espaço, nos gráficos milimetrados. Em seguida, os modelos de gesso foram relacionados por meio do registro de MIC, e repetindo-se os passos descritos, esta posição foi registrada nos três gráficos, sendo que nos blocos laterais do IPC, o registro foi feito agora, na cor vermelha (Fig. 1-4).

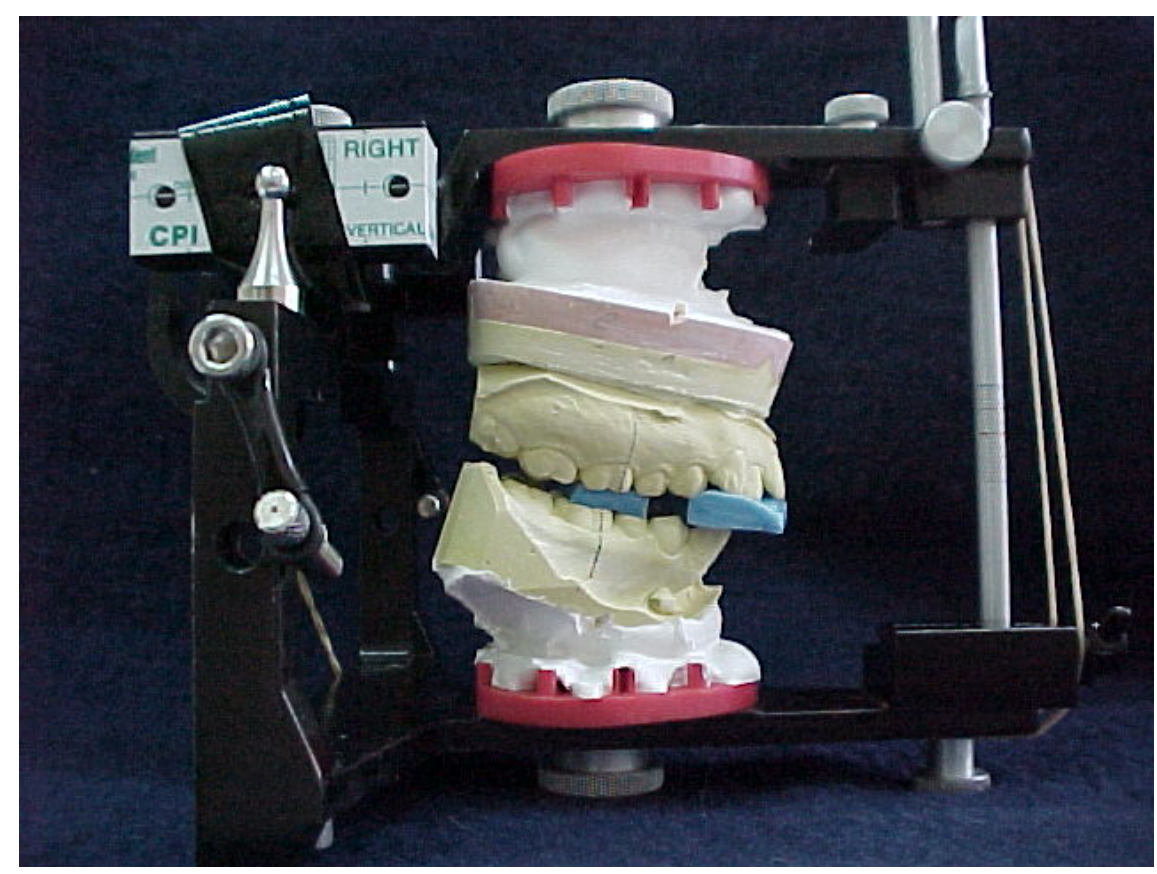

Figura 1 - Demarcação de RC no Indicador de Posição Condilar, com os modelos relacionados por meio do registro de $\mathrm{RC}$ 


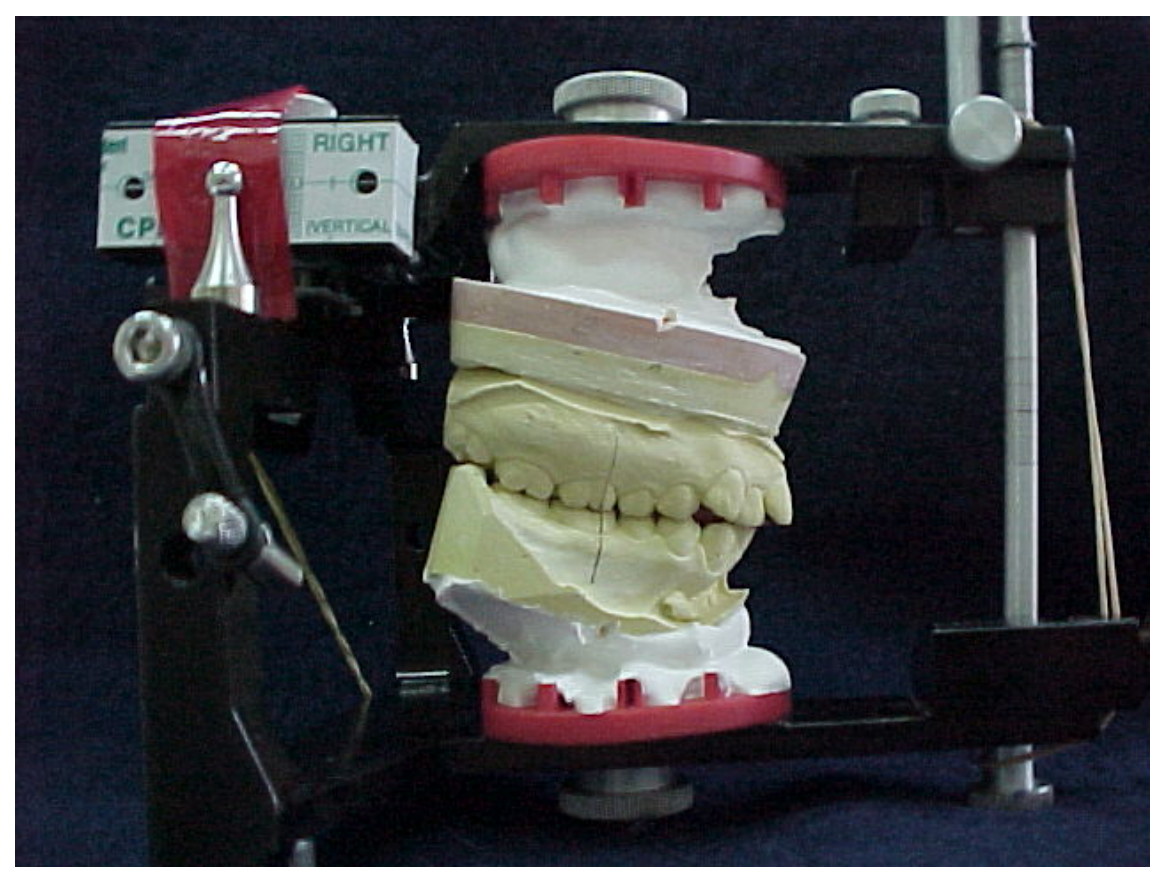

Figura 2 - Demarcação de MIC no Indicador de Posição Condilar, com os modelos relacionados por meio do registro de MIC

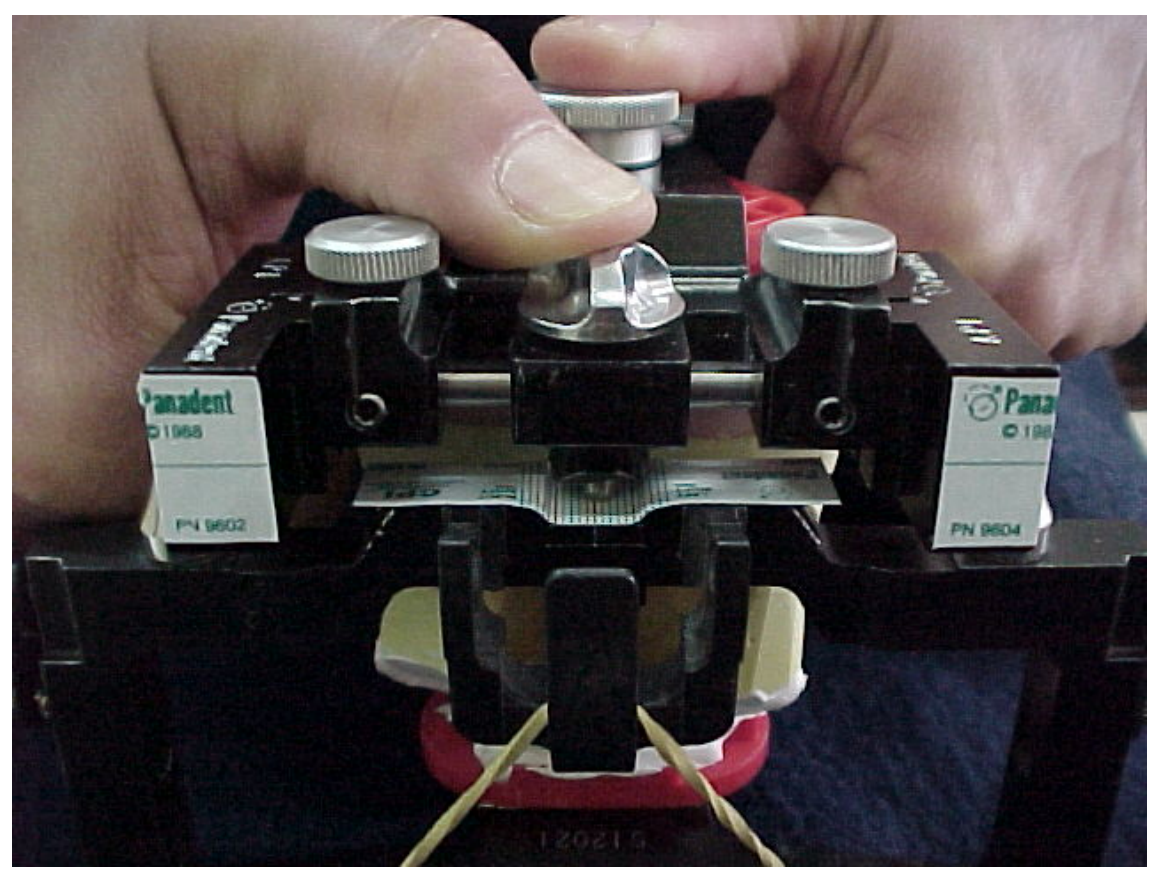

Figura 3 - Demarcação das posições condilares no plano transversal, no gráfico do IPC 


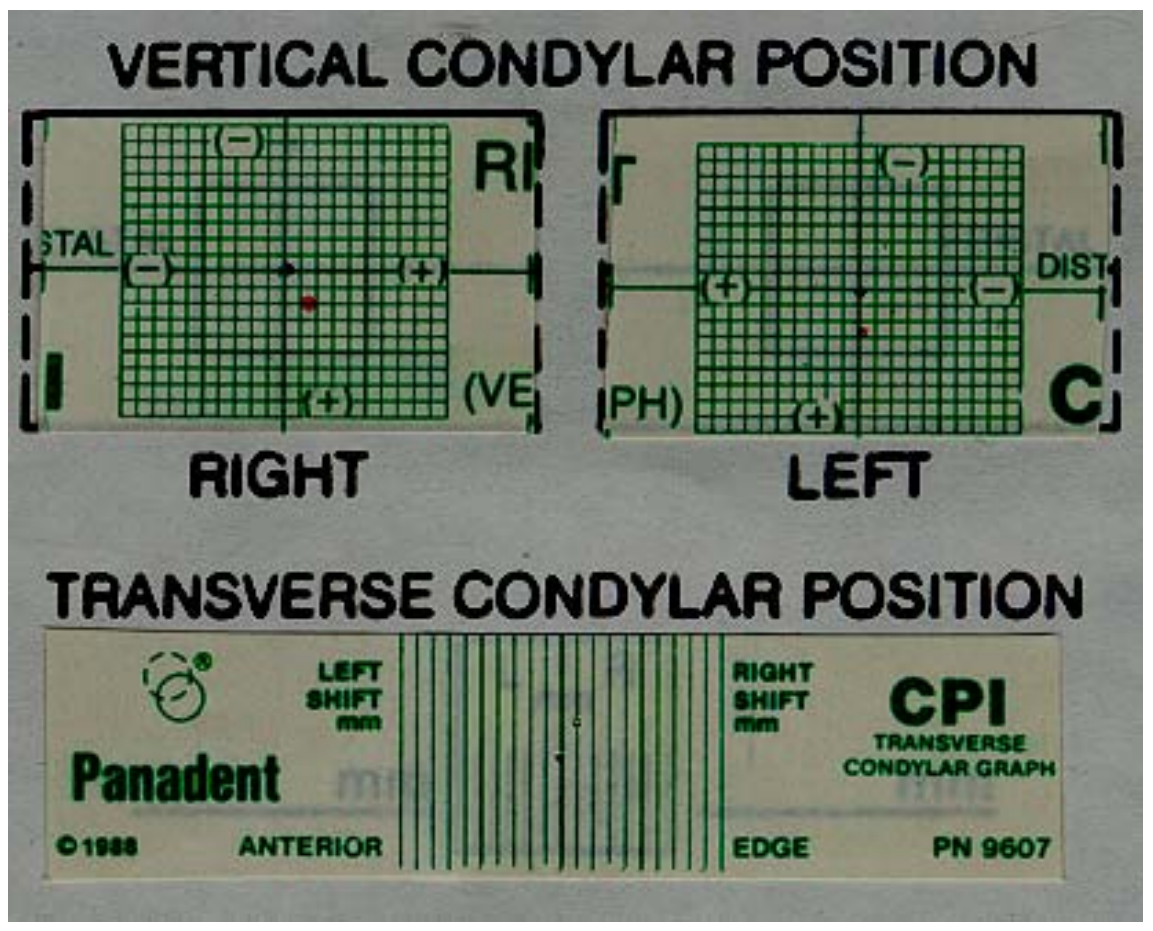

Figura 4 - Gráficos do IPC, dos lados direito e esquerdo, com as posições de RC registradas em preto e as de MIC registradas em vermelho. No gráfico correspondente ao deslocamento transversal, ambas posições são demarcadas com perfurações

Nos blocos laterais, os registros de RC localizaram-se no centro do gráfico, ou muito próximos dele. A medida do deslocamento de MIC em relação a RC, foi feita nas direções horizontal e vertical. No plano horizontal, os deslocamentos de sentido anterior receberam sinal positivo, e os de sentido posterior, receberam sinal negativo. No plano vertical, os deslocamentos de sentido inferior receberam sinal positivo. Não se observou nenhum deslocamento de MIC, em sentido superior, o que poderia caracterizar erro de montagem ou a presença de distúrbio degenerativo das ATM (Wood \& Elliott, 1994) .

No plano transversal, os registros de MIC localizados à direita de RC receberam sinal positivo, e à esquerda, sinal negativo. 
As diferenças verticais, horizontais e transversais, entre as demarcações de RC e MIC, foram medidas com aproximação de décimos de milímetro, por meio de lupa milimetrada Panadent ${ }^{10}$.

4.2.7. Avaliação do estágio de maturidade esquelética

O estágio de maturidade esquelética foi avaliado por meio de radiografias carpais da mão esquerda, segundo método de Fishman (1982) apud Ursi (1994).

\subsubsection{Método estatístico}

As variáveis foram representadas por média, desvio padrão (D.P.) e mediana. Foram utilizados testes não paramétricos devido à grande variabilidade dos dados

A comparação entre duas amostras independentes, isto é, grupo Experimental e Controle, Sexo masculino e feminino e pacientes dentro e fora do período de crescimento acelerado, foi feita pela Prova não paramétrica de Mann-Whitney (U).

A comparação entre duas amostras relacionadas, isto é, lados direito e esquerdo, foi feita pela Prova não paramétrica de Wilcoxon (z).

A correlação entre as medidas relativas a tempo (cronológicas, de maturidade e tempo de uso da placa) e as medidas de discrepância foi testada pelo coeficiente de correlação por postos de Spearman $\left(r_{s}\right)$.

As variáveis "idade" e "maturidade esquelética" mostraram variabilidade pequena, o que possibilitou a suposição de distribuição normal 
dos dados. A comparação entre essas medidas nos grupos Experimental e Controle, foi feita pelo teste "t" de Student, para amostras independentes.

As medidas de discrepância no sentido vertical mostraram correlação linear significante com a maturidade óssea e com a idade cronológica. Os grupos Experimental e Controle mostraram diferença estatisticamente significante em relação a esses mesmos parâmetros; portanto, as medidas de discrepância foram corrigidas a partir de um modelo de regressão linear múltiplo usando como variável dependente, a medida de discrepância, e como variáveis independentes, a idade cronológica e a maturidade esquelética.

A proporção de casos com deslocamentos condilares iguais ou maiores que $2 \mathrm{~mm}$, nos sentidos vertical e horizontal dos lados direito e esquerdo, nos grupos Experimental e Controle, foi definida em porcentagem.

A comparação entre os grupos Experimental e Controle, em relação àquelas proporções, foi feita pelo teste não paramétrico do Qui-quadrado $\left(X^{2}\right)$.

Adotou-se o nível de significância de 0,05 ( $\alpha=5 \%$ ). Níveis descritivos $(P)$ inferiores a esse valor foram considerados significantes e representados por*. 


\section{RESULTADOS}

Os valores originais, correspondentes às variáveis estudadas nos grupos Experimental e Controle, assim como os valores corrigidos do IPC vertical (IPC vert) do grupo Experimental, estão contidos no apêndice A.

As idades cronológicas e os estágios de maturidade esquelética dos indivíduos do grupo Experimental e Controle, além dos tempos totais de uso da placa desprogramadora do grupo Experimental são também, mostradas em anexos.

As comparações entre os grupos Experimental e Controle, em relação às variáveis IPC vert D, IPC vert E, IPC hor D, IPC hor E, e IPC transv, estão contidas na tabela 5.1 .

A comparação entre os grupos Experimental e Controle, em relação às variáveis "idade cronológica" e "maturidade esquelética", feita pelo teste "t" de Student, encontra-se na tabela 5.2.

A tabela 5.3 apresenta as comparações entre homens e mulheres do grupo Experimental, dos deslocamentos verticais, horizontais, dos lados direito e esquerdo, além do transversal. Os mesmos dados relativos ao grupo Controle, encontram-se na tabela 5.4. 
Os resultados da comparação entre os lados direito e esquerdo do grupo Experimental, encontram-se na tabela 5.5 e os do grupo Controle, estão expressos na tabela 5.6.

Os testes de correlação entre as medidas relativas a tempo (idade cronológica, maturidade esquelética e tempo de uso da placa) e as medidas de deslocamento do grupo Experimental são apresentados nas tabelas 5.7 e 5.8 .

As correlações entre idade cronológica ao início do uso da placa, ao final do uso da placa, e medida de deslocamento condilar no sentido vertical dos lados direito e esquerdo, são demonstradas nos Gráficos 5.1, 5.2, 5.5 e 5.6, respectivamente.

As correlações entre estágio de maturidade esquelética ao início do uso da placa, ao final do uso da placa, e medida de deslocamento condilar no sentido vertical dos lados direito e esquerdo, são demonstradas nos Gráficos 5.3, 5.4, 5.7 e 5.8, respectivamente.

A análise das variáveis corrigidas pela idade cronológica e maturidade esquelética, na data do Rx, é apresentada na página 91 .

A comparação entre os valores corrigidos do grupo Experimental e os dados originais do grupo Controle, relativos ao deslocamento condilar no sentido vertical, dos lados direito e esquerdo está contida na tabela 5.10.

A comparação entre os grupos Experimental e Controle, em relação à proporção de casos com valores iguais ou superiores a $2 \mathrm{~mm}$, nas variáveis deslocamento condilar vertical e horizontal dos lados direito e esquerdo, e deslocamento transversal, é apresentada na tabela 5.11. 
Tabela 5.1 - Comparação entre os grupos Experimental e Controle, em relação às seguintes variáveis: Deslocamento condilar no sentido vertical dos lados direito e esquerdo (IPC vert D e IPC vert E), Deslocamento condilar no sentido horizontal dos lados direito e esquerdo (IPC hor D e IPC hor E) e Deslocamento condilar transversal (IPC transv)

\begin{tabular}{lccc}
\hline & $\begin{array}{c}\text { Experimental } \\
(n=22)\end{array}$ & $\begin{array}{c}\text { Controle } \\
(n=23)\end{array}$ & \\
\cline { 2 - 4 } Medida & Média \pm D.P. & Média \pm D.P. & Comparação \\
& Mediana & $1,31 \pm 0,72$ & $U=44,0$ \\
\hline IPC vert D & $4,24 \pm 2,53$ & 1,10 & $P<0,001$ * \\
& 3,25 & $1,86 \pm 0,64$ & $U=64,5$ \\
IPC vert E & $3,86 \pm 2,72$ & 1,20 & $P<0,001$ * \\
\hline IPC hor D & 3,10 & $-0,13 \pm 0,66$ & $U=188,5$ \\
& $-0,72 \pm 1,53$ & $-0,10$ & $P=0,143$ \\
\hline IPC hor E & $-0,85$ & $-0,11 \pm 0,73$ & $U=211,0$ \\
& $-0,51 \pm 1,98$ & $-0,10$ & $P=0,340$ \\
\hline IPC transv & $0,03 \pm 0,87$ & $-0,03 \pm 0,30$ & $U=237,5$ \\
& $-0,15$ & $-0,10$ & $P=0,724$ \\
\hline
\end{tabular}

* significante no nível de 0,1\%

Tabela 5.2 - Comparação entre os grupos Experimental e Controle em relação às seguintes variáveis: Idade cronológica e Maturidade esquelética no momento da avaliação

$\begin{array}{cc}\begin{array}{c}\text { Experimental } \\ (n=22)\end{array} & \text { Controle } \\ (n=23)\end{array}$




\begin{tabular}{lccc}
\cline { 2 - 4 } Variável & Média \pm D.P. & Média \pm D.P. & Comparação \\
Mediana & Mediana & \\
\hline Idade Cronológica & $14 \mathrm{a} 8 \mathrm{~m} \pm 1 \mathrm{a} 5 \mathrm{~m}$ & $16 \mathrm{a} 8 \mathrm{~m} \pm 1 \mathrm{a} 5 \mathrm{~m}$ & $\mathrm{t}=4,81$ \\
& $15 \mathrm{a}$ & $16 \mathrm{a} 4 \mathrm{~m}$ & $\mathrm{P}<0,001$ * \\
\hline Maturidade & $8 \mathrm{a} 7 \mathrm{~m} \pm 2 \mathrm{a} 1 \mathrm{~m}$ & $10 \mathrm{a} 5 \mathrm{~m} \pm 1 \mathrm{a} 2 \mathrm{~m}$ & $\mathrm{t}=3,58$ \\
Esquelética & $9 \mathrm{a}$ & $11 \mathrm{a}$ & $\mathrm{P}=0,001$ * \\
\hline
\end{tabular}

* significante no nível de 0,1\%

Tabela 5.3 - Comparação entre as medidas nos homens e mulheres do grupo Experimental, em relação às seguintes variáveis: Deslocamento condilar no sentido vertical dos lados direito e esquerdo (IPC vert D e IPC vert E), Deslocamento condilar no sentido horizontal dos lados direito e esquerdo (IPC hor D e IPC hor E) e Deslocamento condilar transversal (IPC transv)

\begin{tabular}{lccc}
\hline & $\begin{array}{c}\text { Sexo Masculino } \\
(n=11)\end{array}$ & $\begin{array}{c}\text { Sexo Feminino } \\
(n=11)\end{array}$ & \\
\cline { 2 - 4 } Medida & Média \pm D.P. & Média \pm D.P. & Comparação \\
& Mediana & Mediana & \\
\hline IPC vert D & $4,44 \pm 2,30$ & $4,03 \pm 2,84$ & $U=51,0$ \\
& 3,90 & 2,80 & $P=0,532$ \\
\hline IPC vert E & $4,31 \pm 2,68$ & $3,40 \pm 2,81$ & $U=46,5$ \\
& 3,70 & 2,50 & $P=0,358$ \\
\hline IPC hor D & $-1,07 \pm 1,71$ & $-0,36 \pm 1,31$ & $U=46,0$ \\
& $-0,70$ & $-1,00$ & $P=0,341$ \\
\hline IPC hor E & $-0,67 \pm 2,40$ & $-0,35 \pm 1,57$ & $U=56,5$ \\
& $-0,20$ & $-0,40$ & $P=0,793$ \\
\hline IPC transv & $0,06 \pm 1,03$ & $-0,01 \pm 0,72$ & $U=57,0$ \\
& $-0,10$ & $-0,30$ & $P=0,818$ \\
\hline
\end{tabular}

Tabela 5.4 - Comparação entre as medidas nos homens e mulheres do grupo Controle, em relação às seguintes variáveis: Deslocamento condilar no sentido vertical dos lados direito e esquerdo (IPC vert D e IPC vert E), Deslocamento condilar no sentido horizontal dos lados direito e esquerdo (IPC hor D e IPC hor E) e Deslocamento condilar transversal (IPC transv)

\begin{tabular}{|c|c|c|c|}
\hline & $\begin{array}{l}\text { Sexo Masculino } \\
\quad(n=10)\end{array}$ & $\begin{array}{l}\text { Sexo Feminino } \\
\quad(n=13)\end{array}$ & \\
\hline Medida & $\begin{array}{c}\text { Média } \pm \text { D.P. } \\
\text { Mediana }\end{array}$ & $\begin{array}{c}\text { Média } \pm \text { D.P. } \\
\text { Mediana }\end{array}$ & Comparação \\
\hline IPC vert D & $\begin{array}{c}1,26 \pm 0,81 \\
1,20\end{array}$ & $\begin{array}{c}1,35 \pm 0,68 \\
1,10\end{array}$ & $\begin{array}{c}U=61,5 \\
P=0,827\end{array}$ \\
\hline
\end{tabular}




\begin{tabular}{lccc}
\hline IPC vert $E$ & $0,92 \pm 0,65$ & $1,21 \pm 0,63$ & $\mathrm{U}=48,0$ \\
& 0,70 & 1,30 & $\mathrm{P}=0,289$ \\
\hline IPC hor $\mathrm{D}$ & $-0,01 \pm 0,68$ & $-0,23 \pm 0,66$ & $\mathrm{U}=56,5$ \\
& $-0,05$ & $-0,50$ & $\mathrm{P}=0,597$ \\
\hline IPC hor $\mathrm{E}$ & $0,07 \pm 0,93$ & $-0,25 \pm 0,52$ & $\mathrm{U}=46,0$ \\
& 0,40 & $-0,20$ & $\mathrm{P}=0,238$ \\
\hline IPC transv & $-0,05 \pm 0,35$ & $-0,02 \pm 0,28$ & $\mathrm{U}=62,0$ \\
& $-0,05$ & $-0,10$ & $\mathrm{P}=0,851$ \\
\hline
\end{tabular}

Tabela 5.5 - Comparação entre as medidas nos lados direito e esquerdo no grupo Experimental, em relação às seguintes variáveis: Deslocamento condilar no sentido vertical (IPC vert D e IPC vert E) e Deslocamento condilar no sentido horizontal (IPC hor D e IPC hor E)

\begin{tabular}{lccc}
\hline \multirow{3}{*}{ Medida } & Lado Direito & Lado Esquerdo & \\
\cline { 2 - 4 } & Média \pm D.P. & Média \pm D.P. & Comparação \\
& Mediana & Mediana & \\
\hline IPC vert & $4,24 \pm 2,53$ & $3,86 \pm 2,72$ & $\mathrm{z}=2,24$ \\
& 3,25 & 3,10 & $\mathrm{P}=0,025$ * \\
\hline IPC hor & $-0,72 \pm 1,53$ & $-0,51 \pm 1,98$ & $\mathrm{z}=0,67$ \\
& $-0,85$ & $-0,35$ & $\mathrm{P}=0,502$ \\
\hline
\end{tabular}

* Significante no nível de 2,5\% 
Tabela 5.6 - Comparação entre as medidas nos lados direito e esquerdo no grupo Controle, em relação às seguintes variáveis: Deslocamento condilar no sentido vertical (IPC vert D e IPC vert E) e Deslocamento condilar no sentido horizontal (IPC hor D e IPC hor E)

\begin{tabular}{lccc}
\hline \multirow{3}{*}{ Medida } & Lado Direito & Lado Esquerdo & \\
\cline { 2 - 4 } & Média \pm D.P. & Média \pm D.P. & Comparação \\
& Mediana & Mediana & \\
\hline IPC vert & $1,31 \pm 0,72$ & $1,86 \pm 0,64$ & $\mathrm{z}=1,85$ \\
& 1,10 & 1,20 & $\mathrm{P}=0,164$ \\
\hline IPC hor & $-0,13 \pm 0,66$ & $-0,11 \pm 0,73$ & $\mathrm{z}=0,06$ \\
& $-0,10$ & $-0,10$ & $\mathrm{P}=0,948$ \\
\hline
\end{tabular}

Tabela 5.7 - Coeficiente de correlação de Spearman entre as medidas "cronológicas" e de "maturidade esquelética" e as medidas de Deslocamento do grupo Experimental

\begin{tabular}{|c|c|c|c|c|}
\hline Medida & $\begin{array}{c}\text { Idade } \\
\text { cronológica } \\
\text { inicial }\end{array}$ & $\begin{array}{c}\text { Idade } \\
\text { cronológica final }\end{array}$ & $\begin{array}{c}\text { Maturidade } \\
\text { esquelética } \\
\text { inicial }\end{array}$ & $\begin{array}{c}\text { Maturidade } \\
\text { esquelética final }\end{array}$ \\
\hline IPC vert D & $\begin{array}{c}r_{s}=-0,62 \\
P=0,002 *\end{array}$ & $\begin{array}{c}r_{s}=-0,58 \\
P=0,005 \text { * }\end{array}$ & $\begin{array}{c}r_{s}=-0,68 \\
P<0,001 \text { * }\end{array}$ & $\begin{array}{c}r_{s}=-0,65 \\
P=0,001 *\end{array}$ \\
\hline IPC vert E & $\begin{array}{c}r_{s}=-0,54 \\
P=0,009 \text { * }\end{array}$ & $\begin{array}{c}r_{s}=-0,51 \\
P=0,015 \text { * }\end{array}$ & $\begin{array}{c}r_{s}=-0,71 \\
P<0,001 \text { * }\end{array}$ & $\begin{array}{c}r_{s}=-0,72 \\
P<0,001 \text { * }\end{array}$ \\
\hline IPC hor D & $\begin{array}{c}r_{s}=0,10 \\
P=0,667\end{array}$ & $\begin{array}{r}r_{s}=0,05 \\
P=0,821\end{array}$ & $\begin{array}{r}r_{s}=0,12 \\
P=0,533\end{array}$ & $\begin{array}{r}r_{s}=0,14 \\
P=0,533\end{array}$ \\
\hline IPC hor E & $\begin{array}{r}r_{s}=0,08 \\
P=0,732\end{array}$ & $\begin{array}{c}r_{s}=0,04 \\
P=0,857\end{array}$ & $\begin{array}{r}r_{s}=0,13 \\
P=0,567\end{array}$ & $\begin{array}{r}r_{s}=0,15 \\
P=0,505\end{array}$ \\
\hline IPC transv & $\begin{array}{r}r_{s}=0,33 \\
P=0,137\end{array}$ & $\begin{array}{r}r_{s}=0,31 \\
P=0,163\end{array}$ & $\begin{array}{r}r_{s}=0,11 \\
P=0,641\end{array}$ & $\begin{array}{r}r_{s}=0,10 \\
P=0,653\end{array}$ \\
\hline
\end{tabular}

* Significante no nível de 0,1\%

* Significante no nível de 0,2\%

* Significante no nível de 0,5\%

* Significante no nível de 0,9\%

* Significante no nível de 0,15\% 
Tabela 5.8 - Coeficiente de correlação de Spearman entre o tempo de uso da placa desprogramadora e as medidas de Deslocamento do grupo Experimental

\begin{tabular}{|c|c|}
\hline Medida & $\begin{array}{c}\text { Tempo de uso da } \\
\text { placa }\end{array}$ \\
\hline \multirow[t]{2}{*}{ IPC vert D } & $r_{s}=-0,10$ \\
\hline & $P=0,645$ \\
\hline \multirow[t]{2}{*}{ IPC vert E } & $r_{s}=-0,12$ \\
\hline & $P=0,589$ \\
\hline \multirow[t]{2}{*}{ IPC hor D } & $r_{s}=0,38$ \\
\hline & $P=0,085$ \\
\hline \multirow[t]{2}{*}{ IPC hor E } & $r_{s}=0,10$ \\
\hline & $P=0,650$ \\
\hline \multirow[t]{2}{*}{ IPC transv } & $r_{s}=0,04$ \\
\hline & $P=0,865$ \\
\hline
\end{tabular}


Tabela 5.9 - Comparação entre as medidas nos pacientes dentro e fora do período de crescimento acelerado do grupo Experimental, em relação às seguintes variáveis: Deslocamento condilar no sentido vertical dos lados direito e esquerdo (IPC vert D e IPC vert E), Deslocamento condilar no sentido horizontal dos lados direito e esquerdo (IPC hor D e IPC hor E) e Deslocamento condilar transversal (IPC transv)

\begin{tabular}{|c|c|c|c|}
\hline & $\begin{array}{l}\text { S/ crescimento } \\
\text { acelerado } \\
(n=15)\end{array}$ & $\begin{array}{c}\text { C/ crescimento } \\
\text { acelerado } \\
(\mathrm{n}=7)\end{array}$ & \\
\hline Medida & $\begin{array}{c}\text { Média } \pm \text { D.P. } \\
\text { Mediana }\end{array}$ & $\begin{array}{c}\text { Média } \pm \text { D.P. } \\
\text { Mediana }\end{array}$ & Comparação \\
\hline IPC vert D & $3,07 \pm 1,66$ & $6,73 \pm 2,31$ & $U=9,5$ \\
\hline & 2,80 & 6,70 & $P=0,001$ * \\
\hline IPC vert E & $\begin{array}{c}2,66 \pm 2,08 \\
2,30\end{array}$ & $\begin{array}{c}6,41 \pm 2,15 \\
7,00\end{array}$ & $\begin{array}{c}U=8,0 \\
P=0,001 \text { * }\end{array}$ \\
\hline IPC hor D & $\begin{array}{c}-0,77 \pm 1,47 \\
-1,00\end{array}$ & $\begin{array}{c}-0,60 \pm 1,78 \\
-0,20\end{array}$ & $\begin{array}{c}\mathrm{U}=47,0 \\
\mathrm{P}=0,731\end{array}$ \\
\hline IPC hor E & $\begin{array}{c}-0,48 \pm 1,67 \\
-0,30\end{array}$ & $\begin{array}{c}-0,59 \pm 2,69 \\
-1,30\end{array}$ & $\begin{array}{c}U=46,0 \\
P=0,680\end{array}$ \\
\hline IPC transv & $\begin{array}{c}0,01 \pm 0,81 \\
-0,20\end{array}$ & $\begin{array}{c}-0,06 \pm 1,06 \\
-0,10\end{array}$ & $\begin{array}{c}U=48,0 \\
P=0,783\end{array}$ \\
\hline
\end{tabular}

* Significante no nível de 0,1\% 
Análise das variáveis corrigidas pela idade cronológica e maturidade esquelética na data do $\mathrm{Rx}$

Grupo Experimental:

IPC vert $d=16,458-0,410 *$ Idade $-0,723^{*}$ Maturidade

$R^{2}=0,509$

IPC vert $\mathrm{e}=14,047-0,223^{\star}$ Idade $-0,805^{\star}$ Maturidade

$\mathrm{R}^{2}=0,439$

Grupo Controle:

IPC vert $d=3,877-0,105^{\star}$ Idade $-0,079 *$ Maturidade

$R^{2}=0,074$

IPC vert $e=2,747-0,143 *$ Idade $-0,069 *$ Maturidade

$R^{2}=0,087$

No grupo Controle, o modelo de regressão linear foi não significante, portanto as medidas de discrepância não foram corrigidas pelas variáveis de idade.

No Experimental, o modelo mostrou-se estatisticamente significante com coeficiente de explicação de $44 \%$ no lado esquerdo e $51 \%$ no lado direito, portanto as medidas de discrepância foram corrigidas pelas variáveis de idade.

Tabela 5.10 - Comparação entre os grupos Experimental (valores corrigidos) e Controle (dados originais), em relação às seguintes variáveis: 
Deslocamento condilar no sentido vertical dos lados direito e esquerdo (IPC vert D e IPC vert E)

\begin{tabular}{lccc}
\hline & $\begin{array}{c}\text { Experimental } \\
(\mathrm{n}=22)\end{array}$ & $\begin{array}{c}\text { Controle } \\
(\mathrm{n}=23)\end{array}$ & \\
\cline { 2 - 4 } Medida & Média \pm D.P. & Média \pm D.P. & Comparação \\
& Mediana & Mediana & \\
\hline IPC vert D & $2,74 \pm 2,00$ & $1,31 \pm 0,72$ & $\mathrm{U}=26,0$ \\
& 2,20 & 1,10 & $\mathrm{P}<0,001$ * \\
\hline IPC vert E & $2,44 \pm 1,93$ & $1,86 \pm 0,64$ & $\mathrm{U}=24,0$ \\
& 1,72 & 1,20 & $\mathrm{P}<0,001$ *
\end{tabular}

* Significante no nível de 0,1\%

Tabela 5.11 - Comparação entre os grupos Experimental e Controle em relação à proporção de casos com valores iguais ou superiores a $2 \mathrm{~mm}$ nas seguintes variáveis: Deslocamento condilar no sentido vertical dos lados direito e esquerdo (IPC vert D e IPC vert E), Deslocamento condilar no sentido horizontal dos lados direito e esquerdo (IPC hor D e IPC hor E) e Deslocamento condilar transversal (IPC transv)

\begin{tabular}{|c|c|c|c|}
\hline \multirow[b]{2}{*}{ Medida } & $\begin{array}{l}\text { Experimental } \\
\quad(n=22)\end{array}$ & $\begin{array}{l}\text { Controle } \\
(n=23)\end{array}$ & \multirow[b]{2}{*}{ Comparação } \\
\hline & $\mathrm{n} \quad \%$ & $\mathrm{n} \quad \%$ & \\
\hline IPC vert D & 1881,8 & 626,1 & $\begin{array}{c}\chi^{2}=14,03 \\
P<0,001\end{array}$ \\
\hline IPC vert E & $17 \quad 77,3$ & 4,3 & $\begin{array}{l}\chi^{2}=24,92 \\
P<0,001 \text { * }\end{array}$ \\
\hline IPC hor D & 313,6 & 0,0 & $P=0,109$ \\
\hline IPC hor E & 731,8 & 0,0 & $P=0,004$ * \\
\hline IPC transv & 14,5 & 0,0 & $P=0,489$ \\
\hline
\end{tabular}

- Significante no nível de $0,1 \%$

- Significante no nível de 0,4\% 


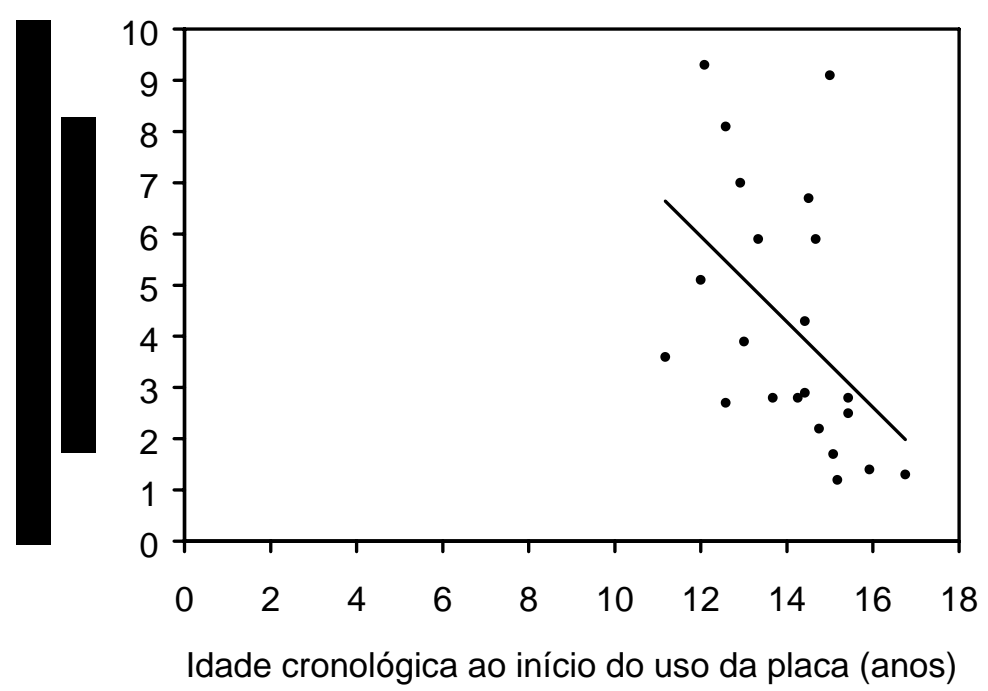

Gráfico 5.1 - Correlação entre idade cronológica ao início do uso da placa e medida de discrepância condilar, no sentido vertical, do lado direito

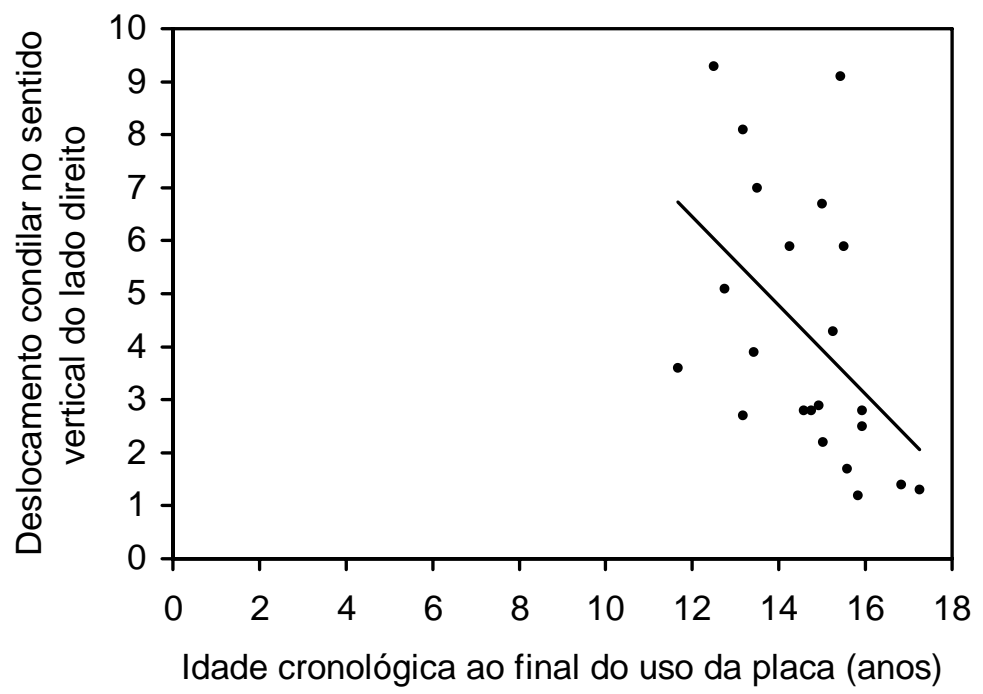

Gráfico 5.2 - Correlação entre idade cronológica ao final do uso da placa e medida de Deslocamento condilar, no sentido vertical, do lado direito 


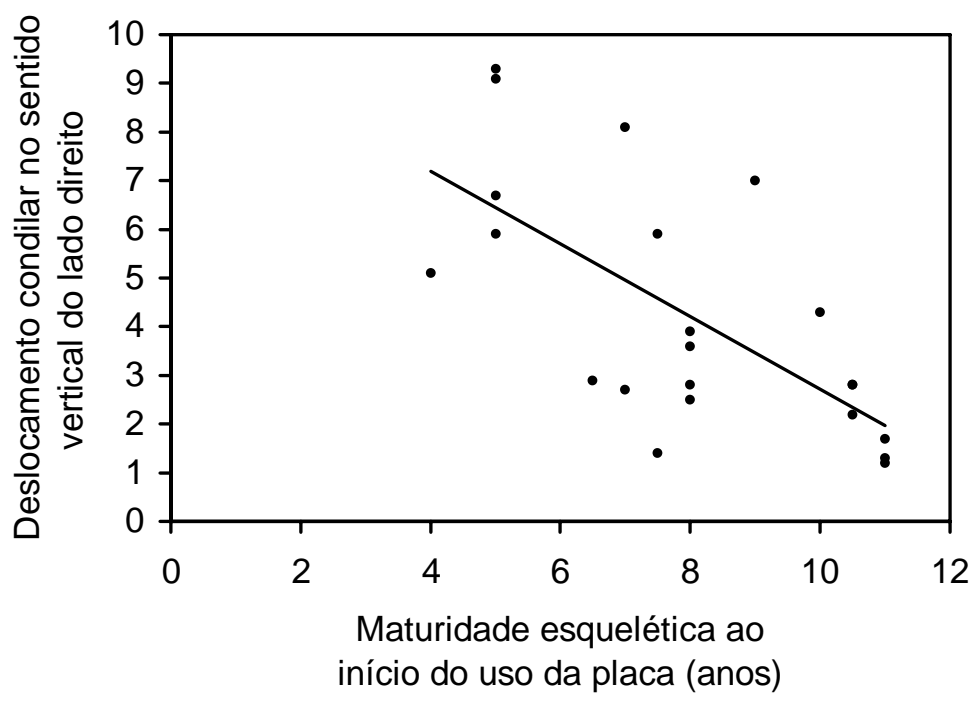

Gráfico 5.3 - Correlação entre maturidade esquelética ao início do uso da placa e medida de Deslocamento condilar, no sentido vertical, do lado direito

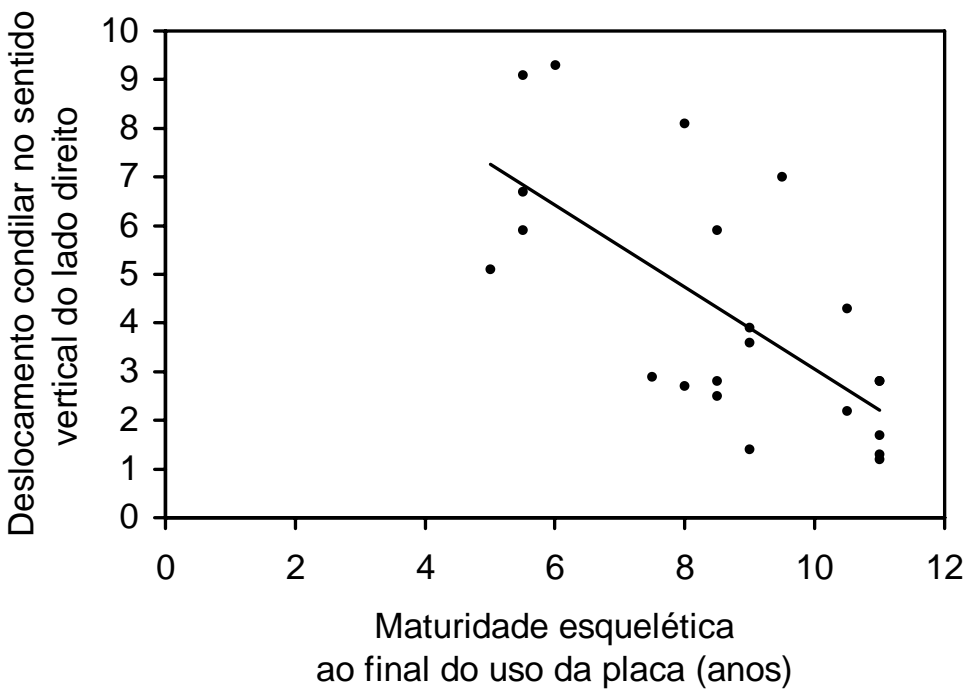

Gráfico 5.4 - Correlação entre maturidade esquelética ao final do uso da placa e medida de Deslocamento condilar, no sentido vertical, do lado direito 


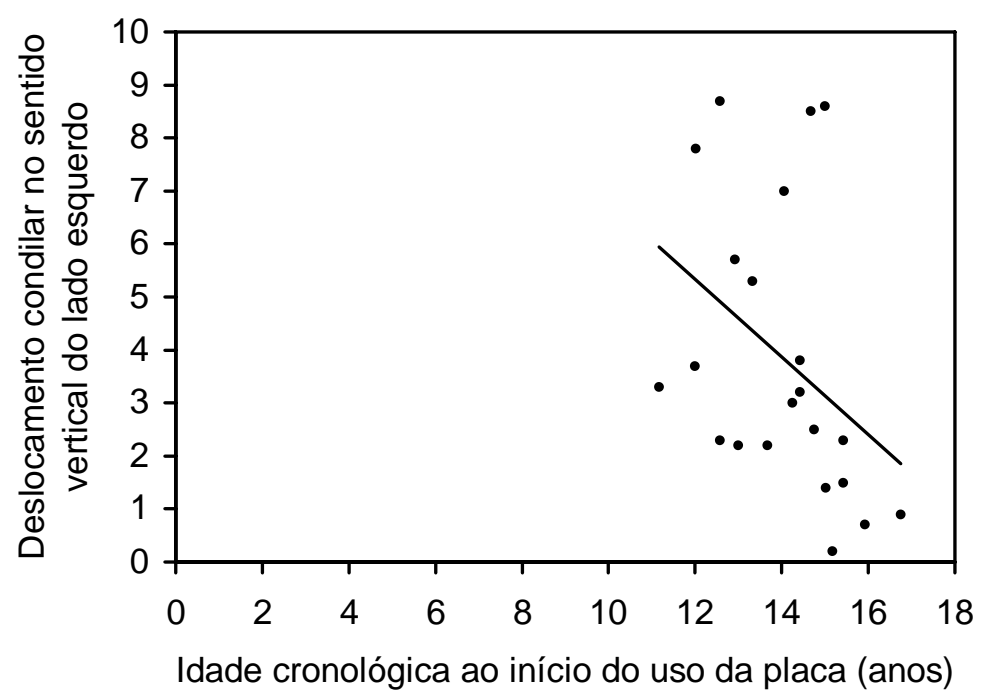

Gráfico 5.5 - Correlação entre idade cronológica ao início do uso da placa e medida de Deslocamento condilar, no sentido vertical, do lado esquerdo

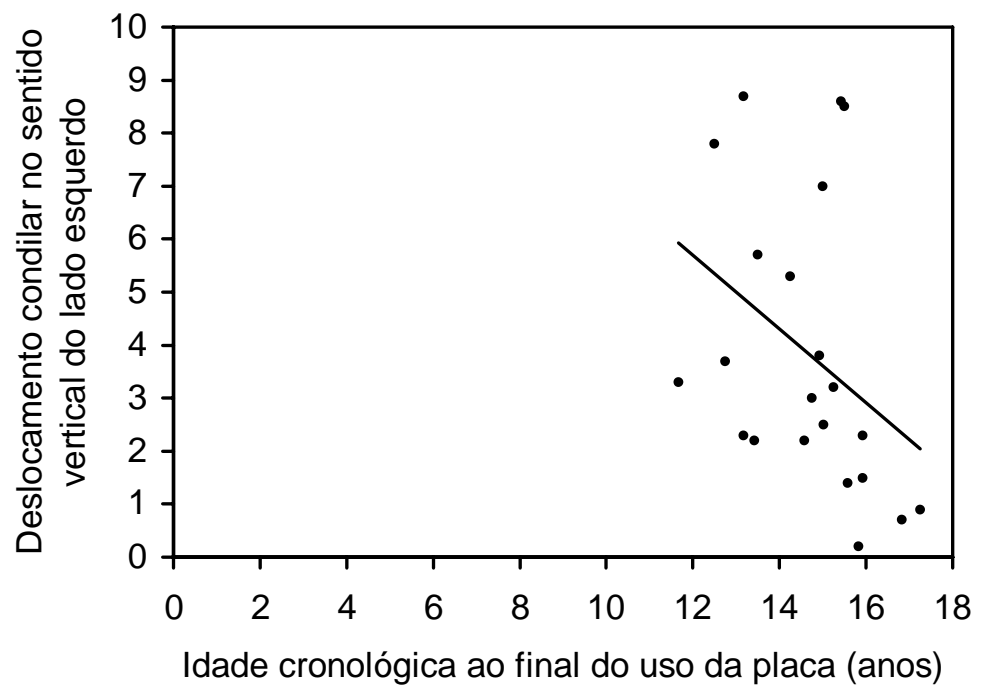

Gráfico 5.6 - Correlação entre idade cronológica ao final do uso da placa e medida de Deslocamento condilar, no sentido vertical, do lado esquerdo 


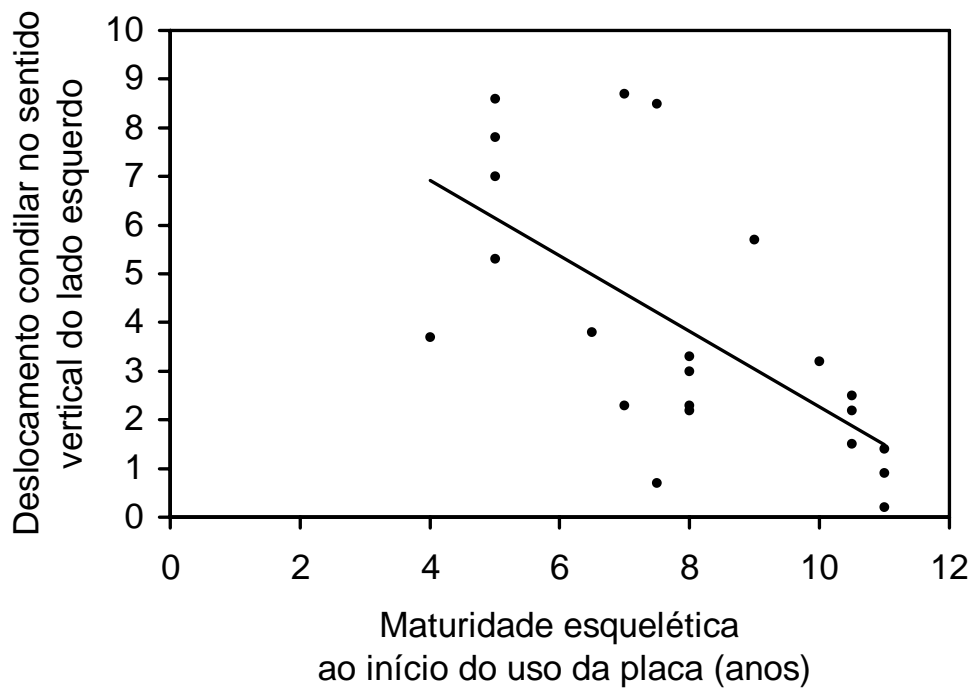

Gráfico 5.7 - Correlação entre maturidade esquelética ao início do uso da placa e medida de Deslocamento condilar, no sentido vertical, do lado esquerdo

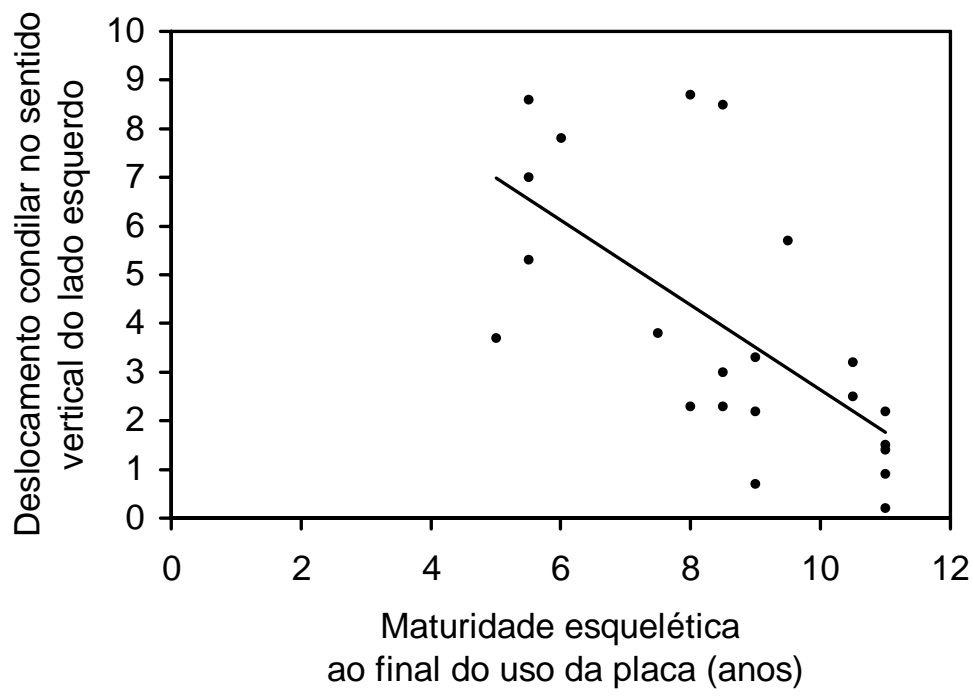

Gráfico 5.8 - Correlação entre maturidade esquelética ao final do uso da placa e medida de Deslocamento condilar, no sentido vertical, do lado esquerdo 


\section{DISCUSSÃO}

A relação cêntrica surgiu como conceito clínico, dada a necessidade de estabelecer-se relacionamento maxilo-mandibular reproduzível, durante o ajuste e a reconstrução oclusais. A escolha daquela relação foi motivada primeiramente, por tratar-se de posição limítrofe ou bordejante, portanto, de mais fácil reprodução. Outro aspecto que parece ter contribuído para a eleição da RC como posição de referência, foi decorrente da presumida proximidade entre ela e a posição condilar que se estabelece durante a máxima intercuspidação dentária (Moffett, 1978).

Inicialmente, a RC foi definida como a posição mais retruída da mandíbula, a partir da qual poderiam ser realizados movimentos de lateralidade (Gysi, 1910a; Sears, 1926; Stuart, 1939). Entretanto, com o tempo, a posição do côndilo em relação à fossa mandibular, representativa de RC, sofreu modificação, merecendo nova definição, caracterizando-se nas direções anterior e superior, esclarecendo assim, a contiguidade com a eminência articular.

Os trabalhos de Ricketts (1950); Ricketts (1953) e Ricketts (1955), segundo os quais os côndilos encontram-se centralizados nas fossas mandibulares na posição de oclusão dentária, respeitadas freqüentes 
variações individuais, contribuíram para as mudanças do conceito original de $\mathrm{RC}$.

Após críticas severas e a proposição de novos critérios feitas por Dawson (1974), os côndilos foram diferentemente definidos, caracterizandose em RC quanto à localização ântero-superior, na fossa mandibular.

Embora se expressando à custa de diferentes termos próprios, enfatizando um ou outro detalhe e considerando também, a localização do disco articular, diversos autores adotaram aquela nova relação côndilo-fossa como representativa de $\mathrm{RC}$, aceita atualmente, quase com unanimidade (Dawson, 1974; Dawson, 1995; Ide \& Nakazawa, 1991; Neff, 1995; Okeson, 1998; Roth, 1981a; Schweikert,1985; Weinberg, 1979; Williamson et al., 1979 apud Roth, 1981a).

Assim, de acordo com o glossário de termos da The Academy of Denture Prosthetics (1987), RC é definida como a relação maxilo-mandibular na qual os côndilos se articulam com a região mais fina e avascular dos respectivos discos, estando o conjunto numa posição ântero-superior, de encontro à parede posterior da eminência articular.

Van Blarcom (1994) complementa que a RC independe dos contatos dentários, sendo identificada clinicamente, quando a mandíbula é dirigida ântero-superiormente, e restrita a um movimento de rotação em torno de um eixo horizontal transverso.

Durante o período de evolução do conceito de RC, apareceram diferentes termos que contribuíram para a controvérsia relacionada ao assunto, tais como "fechamento bordejante posterior", "fechamento 
relaxado", "posição sustentada", "posição de eixo de bisagra", "posição ligamentosa", "posição de contato retruído " e "posição terminal do eixo de bisagra" (Becker \& Kaiser, 1993).

Okeson (1998), por sua vez, refere-se à posição ideal do côndilo na fossa, como a de estabilidade músculo-esquelética.

As mudanças ocorridas nas definições de RC demonstram que a motivação inicial de adotar-se uma posição bordejante de fácil reprodução foi sendo substituída por posição harmonizada com os aspectos anatômicos, histológicos e funcionais do sistema estomatognático.

Seguindo aquela linha de raciocínio, Ide \& Nakazawa (1991) justificam que, segundo a definição atual de RC, as estruturas internas das ATM guardam a relação de proximidade necessária para a correta função articular, como ocorre em todas as demais articulações. Já, segundo a definição original de RC, o princípio da proximidade entre as superfícies articulares seria desrespeitado.

Lauritzen (1974) e Ide \& Nakazawa (1991) também encontram justificativa para a definição atual de RC, ao analisar os tecidos que compõem as ATM. Os autores descrevem regiões articulares com características histológicas que parecem melhor aparelhadas para suportar cargas funcionais. Citam como exemplo, a transformação do fino periósteo que recobre a fossa mandibular, em tecido conjuntivo fibroso denso avascular, na superfície póstero-inferior da eminência articular, e nas superfícies superior e anterior do côndilo. As diferenças histológicas entre a porção central, fina, avascular, sem enervação do disco articular, e as 
demais áreas do mesmo, são apontadas, juntamente com o exemplo anterior, como indicadores das áreas de trabalho da ATM.

A orientação das fibras dos músculos elevadores da mandíbula e a direção das forças aplicadas por eles, apontam também, para a localização súpero-anterior dos côndilos, nas respectivas fossas mandibulares. Estudo eletromiográfico realizado por Williamson (1979) apud Roth (1981a), confirma ser aquela a posição fisiológica dos côndilos, determinada pela musculatura.

Assim, a RC constitui segundo vários autores, importante posição de referência, quando indicados tratamentos da oclusão. Para eles, aquela posição condilar deve ser mantida no momento da máxima intercuspidação dentária, ou seja, RC e MIC devem ser coincidentes (Arnett \& Bergman, 1993; Aubrey, 1978; Beyron, 1954; Capp \& Clayton, 1985a; Capp \& Clayton, 1985b; Chiappone, 1975; Dawson, 1973; Dawson, 1995; Gysi, 1910a; Gysi, 1910b; McCollum, 1939a; McCollum, 1939b; Moffett (1978); Okeson, 1998; Roth, 1981a; Schuyler, 1929; Sears, 1929; Williamson, 1983; Wood, 1988).

Outros autores também consideram RC, importante posição de referência para tratamentos da oclusão, não julgando porém, obrigatória a coincidência entre ela e a posição de máxima intercuspidação habitual (Basic, 1993; Ingervall, 1982; Parker, 1993; Schweikert, 1985; Timm et al., 1976).

Já, segundo Johnston et al. (1988), o deslocamento entre RC e MIC tende a recidivar, quando tratado. Portanto, segundo eles, os tratamentos 
oclusais deveriam ser planejados com o fim de evitar qualquer aumento do deslocamento existente, e não, de eliminá-lo.

Por outro lado, autores como Celenza (1978), Guichet (1978) e Ramfjord (1978), acreditam que a máxima intercuspidação deva ocorrer com os côndilos ligeiramente à frente de RC. As justificativas apresentadas incluem a constatação da alta incidência de deslocamento entre ambas posições, em indivíduos com oclusão normal, feita por Posselt (1952).

Observa-se então, na literatura consultada, que os autores são unânimes em considerar a RC, importante posição de referência para realização dos tratamentos oclusais. Divergências surgem porém, quanto à escolha da posição condilar ideal a ser assumida durante a máxima intercuspidação dentária.

Assim, tanto para os adeptos da cêntrica justa como da "liberdade em cêntrica", qualquer tratamento reabilitador só deve ser instituído, depois de definida a posição condilar de RC. A partir dela, estabelece-se então, a posição condilar a ser assumida em MIC, podendo coincidir ou estar ligeiramente à frente dela, dependendo da escola de pensamento à qual se filie o profissional.

A freqüência, o grau e a natureza do deslocamento condilar entre RC e MIC, nas diferentes populações, têm sido estudados por meio de imagens ou da montagem dos modelos em articulador, sendo eventualmente, analisadas também, as possíveis relações entre posição condilar e distúrbios oclusais, musculares e articulares (Abrão, 1991; Alexander et al., 1995; Gaither et al., 1997; Hoffman et al., 1973; Johnston et al., 1988; Milosevic \& 
Samuels, 1998; Pullinger et al., 1985; Pullinger et al., 1986; Pullinger, 1987; Utt et al., 1995; Wood \& Korne, 1992; Wood \& Elliott, 1994).

Avaliações das ATM, feitas por meio de imagens tomográficas, revelam grande variabilidade do grau de concentricidade condilar, tanto em populações sintomáticas como assintomáticas, havendo diferença de distribuição dos côndilos não concêntricos, nos indivíduos do sexo masculino e feminino. Embora a localização posterior do côndilo tenha sido considerada fator predisponente da instabilidade do disco, a variabilidade de posição condilar encontrada dos diversos grupos, desqualifica o método radiográfico como meio exclusivo ou principal de diagnóstico de DTM (Alexander et al., 1995; Pullinger et al., 1985; Pullinger et al., 1986; Weinberg, 1985).

Alexander et al. (1995) dão conta de que 13\% das articulações de pacientes assintomáticos apresentam deslocamento anterior de disco. Os autores relatam também, a ocorrência de ruídos articulares em pacientes com relação côndilo-disco normais. Tais fatos constituem demonstrações práticas da importância e da complexidade envolvidas no exame das ATM, mesmo em pacientes "assintomáticos".

A busca por maior confiabilidade na localização e registro da RC é responsável pela diversidade de materiais e técnicas desenvolvidos com aquela finalidade. Entretanto, independentemente deles, dois aspectos parecem ter fundamental importância para o registro confiável da RC: a estabilidade articular e a desprogramação neuromuscular (Calagna, 1973; Capp \& Clayton, 1985a; Capp \& Clayton, 1985b; Carlson et al., 1993; Dupas 
et al., 1990; Dyer, 1973; Goharian \& Neff, 1980; Hobo \& Iwata, 1985; Koyano et al., 1997; Kinderknecht et al., 1992; Lauritzen, 1974; Lucia, 1964; Neff, 1995; Nelson, 1995; Roura \& Clayton, 1975; Schweikert, 1985; Weinberg, 1991).

A localização da RC pode ser conseguida por meio de diferentes técnicas de manipulação mandibular, que podem ser feitas com apenas uma das mãos (Lauritzen, 1974) ou com as duas mãos, segundo método proposto por Dawson (1973).

O emprego de anteparos na região anterior das arcadas, no momento do registro de RC, como sugerido por Lucia (1964) e Long (1970), tem a finalidade de assegurar ligeira desoclusão dos dentes durante aquele procedimento, modificando-se a propriocepção, e consequentemente, o padrão de fechamento reflexo da mandíbula. Os dispositivos mencionados podem agir também, como ponto de apoio ou fulcro, permitindo assim, que os côndilos alcancem a posição mais súpero-anterior, na fossa mandibular.

Comparações entre os métodos citados têm falhado em apontar uma técnica que possa ser considerada definitivamente melhor que as demais.

Os resultados menos consistentes foram produzidos pela técnica da deglutição ou do fechamento livre, pelo emprego do miomonitor, e de rolos de algodão (Calagna et al., 1973; Carlson et al., 1993; Kantor et al., 1973).

De acordo com Kantor et al. (1973) ; Hobo \& Iwata (1985), a maior repetibilidade dos registros é alcançada aplicando-se a manipulação bimanual de Dawson (1974). 
Já, Capp \& Clayton (1985) encontraram resultados mais consistentes associando-se o "Jig" de Lucia à manipulação mandibular da "guia pela ponta do mento", tanto em indivíduos com, como sem DTM.

Araújo et al. (1988) encontraram resultados semelhantes ao compararem registros de RC, obtidos com o uso do "Jig" de Lucia e dos calibradores de Long.

Entretanto, quando diferentes métodos são comparados com as placas oclusais, estas apresentam rotineiramente, os resultados mais consistentes ou reproduzíveis (Calagna et al., 1973; Capp \& Clayton,1985b; Carlson et al., 1993; Dyer, 1973; Neff, 1995; Nelson, 1995; Weinberg, 1991).

Reconhecendo-se então, a ocorrência de freqüente deslocamento condilar entre RC e MIC na população em geral, e dada a impossibilidade de prever-se o grau e a natureza do mesmo, diversos autores recomendam o uso de dispositivos desprogramadores do sistema neuromuscular. Alguns também indicam a montagem dos modelos em articulador, em RC, em busca de diagnóstico mais preciso, recomendando maior atenção aos aspectos funcionais da oclusão, inclusive em pacientes ortodônticos (Ahlgren \& Posselt, 1963; Arnett \& Bergman, 1993; Calagna et al., 1973; Chang et al., 1997; Dyer, 1973; Gaither et al., 1997; Goharian \& Neff, 1980; McCollum, 1939a; Milosevic \& Samuels, 1998; Neff, 1995; Parker, 1978; Roth, 1973; Roth \& Rolfs, 1981; Schuyler, 1929; Schweikert, 1985; Timm et al., 1976; Utt et al., 1995; Weinberg, 1991; Williamson, 1983; Wood \& Korne, 1992; Wood \& Elliott, 1994).

Sendo assim, avaliou-se neste estudo, o grau de deslocamento 
condilar entre as posições de RC e MIC, em pacientes com dentadura permanente completa até segundos molares, com maloclusão de $\mathrm{Cl} \mathrm{II}$, sem sinais ou sintomas clínicos de DTM tais como: dor articular ou muscular espontânea e/ou durante os movimentos mandibulares, dor à palpação nas ATM, limitação de abertura bucal (abertura máxima menor que $40 \mathrm{~mm}$ ) e travamento ou luxação mandibulares.

Os indivíduos foram divididos em grupo Experimental e Controle, sendo que no grupo Experimental, os pacientes usaram placa oclusal desprogramadora, por um período mínimo de 4 meses e 23 dias, e máximo de 11 meses e 28 dias. O tempo médio de uso das placas foi de 7 meses e 22 dias. No grupo Controle, evidentemente, não se fez uso daquele dispositivo.

A placa desprogramadora, ao ser instituída, justificou a finalidade de analisar-se possível diferença dos deslocamentos condilares entre pacientes assintomáticos desprogramados e assintomáticos não desprogramados.

Como os indivíduos deste estudo foram selecionados entre os candidatos a tratamento ortodôntico inscritos na clínica de ortodontia da FOUSP, houve certa limitação para que fossem encontrados pacientes com as características necessárias, que apresentassem ao mesmo tempo, idades cronológicas e estágios de maturidade esquelética equivalentes para os grupos Experimental e Controle. Assim, comparando-se os dados de ambos os grupos, relativos àquelas duas variáveis, constatou-se que o grupo Experimental é significantemente mais jovem que o grupo Controle 
( $P<0,001$ e $P=0,001$, respectivamente). Em decorrência da referida diferença entre os grupos estudados, foram realizados alguns testes estatísticos a serem mencionados oportunamente, que levaram `a correção de medidas do grupo Experimental, relacionadas aos deslocamentos condilares verticais dos lados direito e esquerdo.

Avaliando-se os deslocamentos condilares entre RC e MIC, nos grupos Experimental e Controle, encontrou-se grande dispersão dos registros, da mesma forma que (Rosner \& Goldberg, 1986; Wood \& Korne 1992; Utt et al. 1995).

Os deslocamentos médios verticais do grupo Controle deste estudo, da ordem de $1,31 \mathrm{~mm}( \pm 0,72)$ do lado direito e de $1,86( \pm 0,64)$ no lado esquerdo, são ligeiramente maiores que os encontrados por Wood \& Korne (1992), com valores médios de $1,24 \mathrm{~mm}$ no lado direito e 1,13 no esquerdo; por Wood \& Elliott (1994) com média de 1,2mm para ambos os lados, e por Utt et al. (1995), com média de 0,91mm para o lado direito e 0,73mm para o esquerdo. Nos estudos mencionados, foi adotado método semelhante de medição dos deslocamentos condilares, embora em nenhum dos três últimos, tenha sido empregado qualquer método de desprogramação neuromuscular, antes dos registros de RC.

Já, os deslocamentos médios verticais do grupo Experimental, tanto originais dos lados direito e esquerdo, $(4,24 \pm 2,53 ; 3,86 \pm 2,72$, respectivamente), como corrigidos direito e esquerdo $(2,74 \pm 2,00 ; 2,44$ $\pm 1,93$, respectivamente), mostram-se bem maiores que os encontrados 
pelos autores citados (Utt et al., 1995; Wood \& Korne, 1992; Wood \& Elliott, 1994).

Em sentido horizontal, os deslocamentos entre RC e MIC observados no grupo Experimental, com média de $-0,72( \pm 0,1,53)$ no lado direito e de $-0,51( \pm 1,98)$ no lado esquerdo, mostram-se também, maiores que os dados correspondentes, encontrados por Wood \& Korne (1992), com valores médios de -0,32mm e $+0,31 \mathrm{~mm}$, nos lados direito e esquerdo respectivamente e por Wood \& Elliott (1994), com valor médio de -0,26mm. Comparando-se os dados obtidos com os de Utt et al. (1995), o deslocamento horizontal do lado direito deste estudo é maior que o encontrado pelo autor citado $(0,63 \mathrm{~mm})$, porém, no lado esquerdo apresentase menor que o valor de $0,64 \mathrm{~mm}$, encontrado por aquele autor.

Os deslocamentos horizontais do grupo Controle, da ordem de $-0,13$ $( \pm 0,66)$ no lado direito e de $-0,11( \pm 0,73)$ no lado esquerdo, apresentam-se por sua vez, menores que os dados correspondentes encontrados pelos autores citados (Utt et al., 1995; Wood \& Korne, 1992; Wood \& Elliott, 1994).

O deslocamento transversal médio encontrado, de $-0,03 \mathrm{~mm}( \pm 0,30)$, é menor que aquele observado por Utt et al. (1995), com dimensão de $0,27 \mathrm{~mm}$.

Os deslocamentos médios encontrados por Rosner \& Goldberg (1986), em pacientes assintomáticos, foram de $0,26 \mathrm{~mm}$ no sentido anterior, $0,78 \mathrm{~mm}$ no sentido inferior e $0,34 \mathrm{~mm}$, no sentido transversal. O autor informa ainda, que $12 \%$ dos indivíduos demonstraram deslocamento transversal maior que $0,6 \mathrm{~mm}$. 
Comparando-se os valores medidos nos grupos Experimental e Controle, encontrou-se diferença estatísticamente significante entre eles, em relação aos deslocamentos condilares originais no sentido vertical, dos lados direito e esquerdo ( $P<0,001$ e $P<0,001$, respectivamente). Pode-se afirmar então, que os deslocamentos condilares em sentido vertical, observados no grupo Experimental, são significantemente maiores do que os do grupo Controle.

Nos demais parâmetros avaliados, ou seja, deslocamentos condilares no sentido horizontal dos lados direito e esquerdo, e deslocamento condilar transversal, não foram encontradas diferenças estatisticamente significantes entre os grupos analisados $(P=0,143, P=0,340$ e $P=0,724$, respectivamente).

Avaliando-se o coeficiente de correlação entre medidas cronológicas e medidas de deslocamento condilar do grupo Experimental, encontrou-se correlação inversa significante entre a idade cronológica ao início do uso da placa, e as medidas de deslocamento no sentido vertical nos lados direito e esquerdo, assim como entre a idade cronológica ao final do uso da placa e aquelas mesmas medidas de deslocamento $(P=0,002, P=0,009, P=0,005$ e $P=0,015$ respectivamente). Portanto, quanto mais velho o paciente, menores os deslocamentos encontrados no sentido vertical.

As correlações encontradas entre a idade inicial e os demais deslocamentos, assim como entre idade final e os referidos deslocamentos, não são estatisticamente significantes $(P>0,05)$. 
Analisando-se o coeficiente de correlação entre estágio de maturidade esquelética e as medidas de deslocamento condilar do grupo Experimental, constatou-se correlação significante entre estágio de maturidade esquelética ao início do uso da placa e as medidas de deslocamento no sentido vertical, nos lados direito e esquerdo, assim como entre o estágio de maturidade esquelética ao final do uso da placa e aquele mesmo deslocamento $(\mathrm{P}<$ $0,001, P<0,001, P=0,001$ e $P<0,001$, respectivamente). As correlações encontradas são inversas, isto é, quanto maior a maturidade esquelética do paciente, menores os deslocamentos encontrados no sentido vertical.

As correlações encontradas entre a maturidade esquelética inicial e os demais deslocamentos, bem como entre maturidade esquelética final e aqueles deslocamentos, não são estatisticamente significantes $(P>0,05)$.

De acordo com Ursi (1994), os períodos de maior velocidade de crescimento localizam-se entre os estágios 4 e 7 , da curva de velocidade de crescimento estatural de Fishman (1982). Compararam-se então, as medidas dos pacientes dentro e fora do período de crescimento acelerado do grupo Experimental, em relação aos deslocamentos condilares verticais, horizontais e transversal, dos lados direito e esquerdo. Encontrou-se diferença estatísticamente significante entre os pacientes dentro e fora do período acelerado de crescimento, em relação aos deslocamentos condilares no sentido vertical, nos lados direito e esquerdo $(P=0,001$ e $P=0,001$ respectivamente). Assim, os deslocamentos encontrados no grupo com crescimento acelerado são significantemente maiores do que os do grupo sem crescimento acelerado. 
Nos demais parâmetros avaliados, os deslocamentos condilares no sentido horizontal dos lados direito e esquerdo e deslocamento condilar transversal, não exibiram diferenças estatisticamente significante entre os grupos analisados $(P=0,731, P=0,680$ e $P=0,783$ respectivamente).

Portanto, tendo-se encontrado diferença estatísticamente significante entre os grupos Experimental e Controle, em relação ao deslocamento condilar vertical nos lados direito e esquerdo, constatado correlação significante daquele deslocamento com idade cronológica e estágio de maturidade esquelética, e observado diferença estatisticamente significante entre os pacientes dentro e fora do período de crescimento acelerado, em relação aos deslocamentos condilares verticais, nos lados direito e esquerdo, foi tomada a decisão de corrigirem-se então, as medidas dos deslocamentos do grupo Experimental a partir de modelo de regressão linear múltiplo, usando a medida de deslocamento como variável dependente e, como variáveis independentes, a idade cronológica e o estágio de maturidade esquelética.

No grupo Controle, o modelo de regressão linear foi não significante, portanto, as medidas de deslocamento não foram corrigidas pelas variáveis de idade.

No grupo Experimental, o modelo mostrou-se estatisticamente significante com coeficiente de explicação de $44 \%$ no lado esquerdo e 51\% no lado direito. Assim, as medidas de deslocamento foram corrigidas pelas variáveis de idade. 
Comparando-se agora, os deslocamentos corrigidos verticais dos lados direito e esquerdo, do grupo Experimental, com os dados originais do grupo Controle, encontrou-se novamente, diferença estatisticamente significante em relação aos deslocamentos condilares no sentido vertical de ambos os lados ( $P<0,001$ e $P<0,001$ respectivamente), isto é, os deslocamentos encontrados no grupo Experimental são significantemente maiores do que os do grupo Controle.

Desta forma, confirma-se a influência do uso das placas desprogramadoras sobre o maior grau de deslocamento condilar vertical, observado nos indivíduos do grupo Experimental. Não se encontrou, porém, correlação significante entre o tempo total de uso da placa e as medidas de deslocamento avaliadas ( $P>0,05$ em todas as correlações). Aquelas diferenças de deslocamentos entre RC e MIC, decorrentes do uso de placa desprogramadora, já haviam sido mencionados por (Calagna et al.,1973; Dyer, 1973; Kovaleski \& De Boever, 1975; Johnston et al., 1988; Contin, 1997).

Não se compreende ainda, o completo mecanismo de ação das placas desprogramadoras que, segundo Nelson (1995), envolve efeitos físicos e placebo. Constata-se, porém, que o uso das mesmas resulta no deslocamento do eixo terminal de rotação mandibular, à medida que a ATM se torna mais estável. Observa-se também, diminuição do deslocamento lateral imediato de Bennett e da inclinação da guia condilar, durante movimento protrusivo (Dyer, 1973). São citados ainda, como efeitos do uso da placa desprogramadora, o relaxamento dos músculos mandibulares, a 
diminuição dos sintomas musculares e da ATM, o alívio do espasmo muscular, o estabelecimento da RC, o aumento da reprodutibilidade dos registros das posições mandibulares, a reparação do equilíbrio oclusal, a interceptação ou, mesmo, a redução do bruxismo, a recuperação da máxima abertura mandibular, a alteração da carga articular, a redução de trauma sobre a ATM promovendo a reparação da mesma, e a influência sobre a propriocepção da membrana periodontal, descondicionando o padrão habitual da função muscular (Beard \& Clayton, 1980; Crispin et al., 1978; Goharian \& Neff, 1980; Kovaleski \& De Boever, 1975; Koyano et al., 1997; Neff, 1995; Nelson, 1995; Perry, 1956; Ramfjord, 1978; Roura \& Clayton, 1975; Solberg et al., 1975; Wood, 1988).

Para Roth (1981), qualquer registro de RC, obtido sem a prévia estabilização mandibular por meio de placas oclusais, está sujeito a críticas.

Johnston et al. (1988) explicam que as placas favorecem maior reposição condilar em RC, o que justificaria então, a ocorrência de deslocamentos maiores entre RC e MIC.

Ramfjord (1978) adverte que nenhum ajuste oclusal ou reconstrução bucal deve ser iniciado, sem o completo relaxamento dos músculos mandibulares. Ele recomenda o uso de placa desprogramadora, com aquele objetivo.

Por outro lado, Kinderknecht et al. (1992) não consideram justificáveis os procedimentos de desprogramação rotineiros, aplicados em pacientes saudáveis antes do registro de RC, apesar de terem constatado deslocamento condilar estatisticamente significante após $12 \mathrm{~h}$ de uso do 
desprogramador anterior de Okeson (1989). Como as diferenças de posição condilar foram menores que $0,5 \mathrm{~mm}$, os autores (Kinderknecht et al., 1992) acreditam que as mesmas não contenham significado clínico.

Contin (1997) afirma que, nos pacientes assintomáticos, a localização do eixo de rotação terminal da mandíbula pode ser obtida após 3h de uso do "Jig" de Lucia. Já, em pacientes com dor miofascial de cabeça e pescoço, foi necessário uso de placa desprogramadora para alcançar-se aquela posição.

Gaither et al. (1997) encontraram, por sua vez, diferença no grau de deslocamento condilar entre RC e MIC, quando comparados registros realizados antes do tratamento ortodôntico, ao término do mesmo e na fase de contenção. Os autores observaram tendência de aumento daquele deslocamento, da fase pré-tratamento até a fase de contenção, especialmente no côndilo esquerdo.

A ocorrência de côndilos excêntricos em indivíduos assintomáticos, com maloclusão de $\mathrm{Cl}$ II div. $1^{\mathrm{a}}$, já havia sido mencionada por Pullinger et al. (1987), que encontraram associação entre aquele tipo de maloclusão e diferenças de postura condilar.

Nas comparações entre homens e mulheres, tanto do grupo Experimental como Controle, não foram encontradas diferenças estatisticamente significantes em relação a todos os deslocamentos avaliados ( $P>0,05$ em todas as comparações).

Da mesma forma, não foram encontradas diferenças estatisticamente significantes entre as medidas de deslocamento condilar nos sentidos vertical e horizontal comparando-se os lados direito e esquerdo, nos 
pacientes do grupo Controle $(P=0,164, P=0,948$, respectivamente), nem entre as medidas do deslocamento condilar no sentido horizontal nos lados direito e esquerdo, nos pacientes do grupo Experimental $(P=0,502)$.

Constatou-se porém, diferença estatisticamente significante entre as medidas do deslocamento condilar no sentido vertical nos lados direito e esquerdo, nos pacientes do grupo Experimental $(P=0,025)$. A medida do deslocamento do lado direito é significantemente maior do que a do lado esquerdo.

Hoffman et al. (1973), ao compararem dados dos lados direito e esquerdo, encontraram diferenças de deslocamento condilar entre RC e MIC, maiores que $0,5 \mathrm{~mm}$, nos sentidos vertical e horizontal, em $10 \%$ da amostra estudada.

Já, segundo Rosner \& Goldberg (1986), 45,3\% da amostra apresentaram diferenças maiores que $0,7 \mathrm{~mm}$, quando comparados deslocamentos condilares dos lados direito e esquerdo, no sentido ânteroposterior. Em sentido inferior, aquela diferença ocorreu em 25,3\% dos indivíduos.

Além das diferenças estatisticamente significantes entre os grupos Experimental e Controle já analisadas, deve-se atentar também, para as diferenças clínicas observadas especialmente no grupo Experimental, ao compararem-se as relações entre os modelos montados em articulador na posição de RC, com aquelas em MIC (Fig. 5-6). 


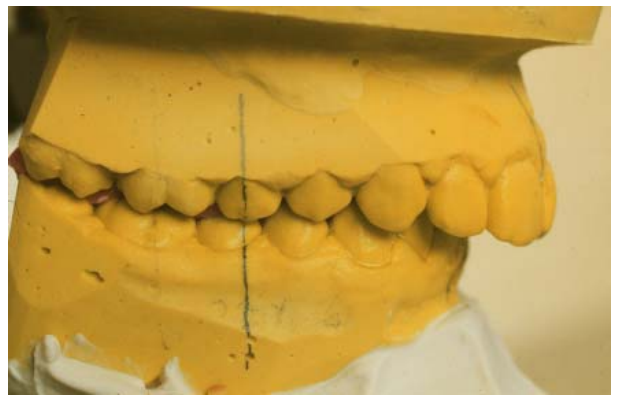

A

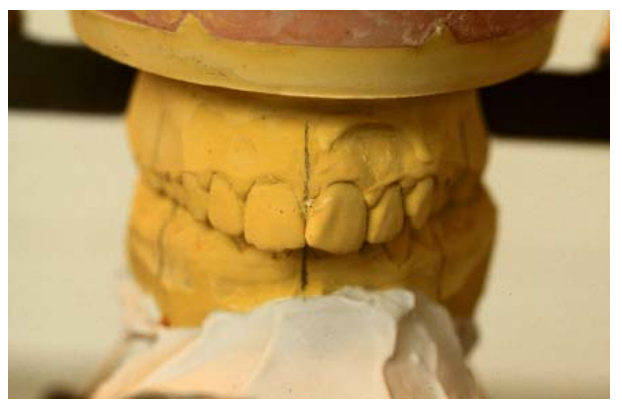

C

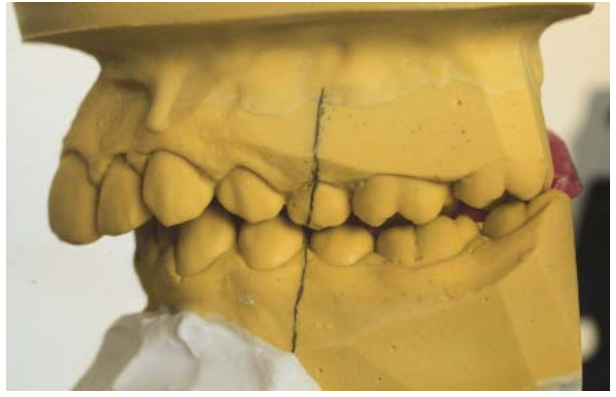

$\mathbf{E}$

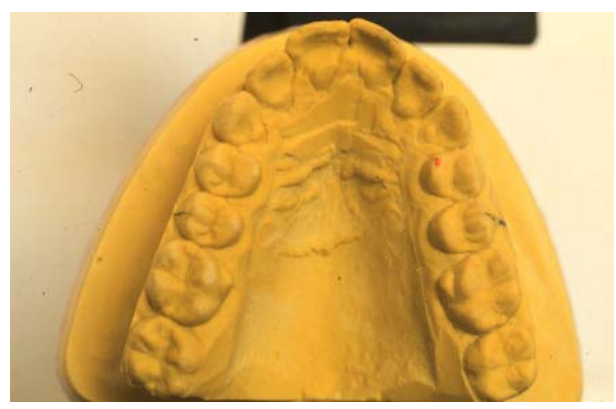

G

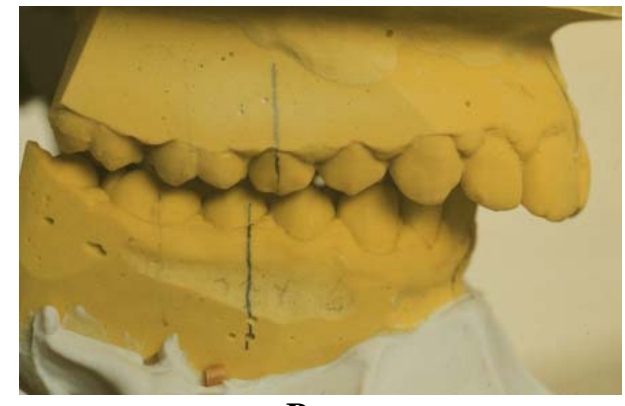

B

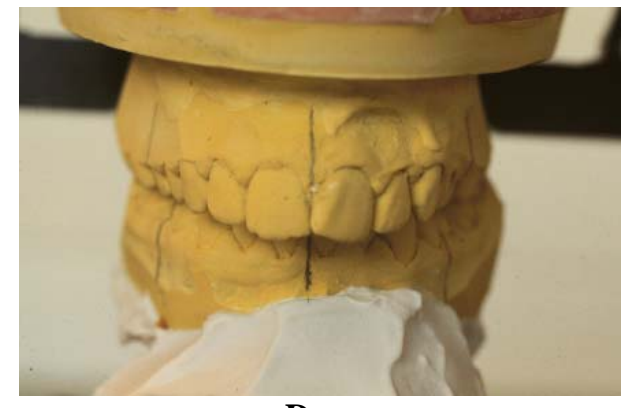

D
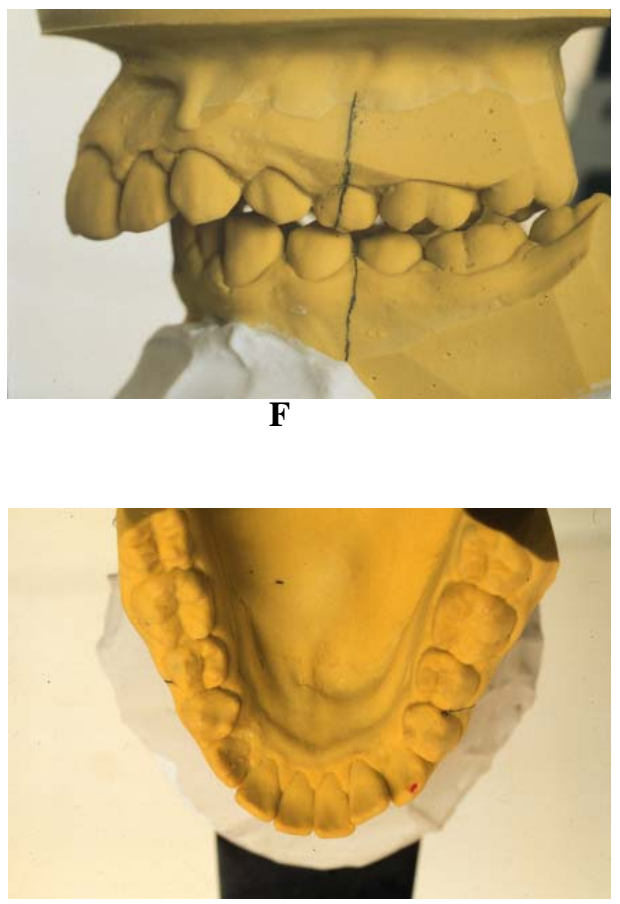

H

Figura 5 - Modelos de paciente do grupo experimental, montados em articulador, relacionados em MIC e em RC. A - Vista do lado direito, em MIC. B - Vista do lado direito, em RC. C - Vista frontal, em MIC. D - Vista frontal, em RC. E - Vista do lado esquerdo, em MIC. F - Vista do lado esquerdo, em RC. G - Vista oclusal superior, com o primeiro ponto de contato em RC, marcado em vermelho. $\mathbf{H}$ - Vista oclusal inferior, com o primeiro ponto de contato em $\mathrm{RC}$, marcado em vermelho 


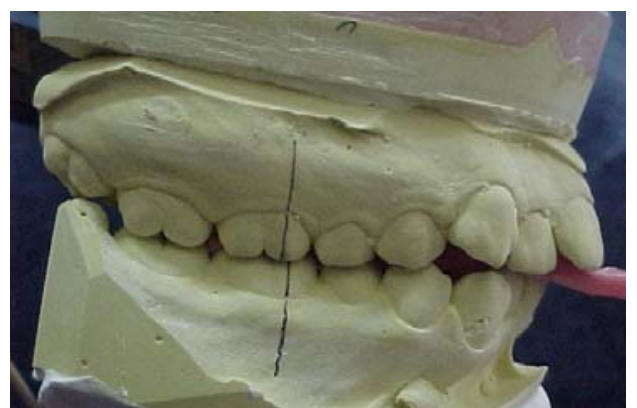

A

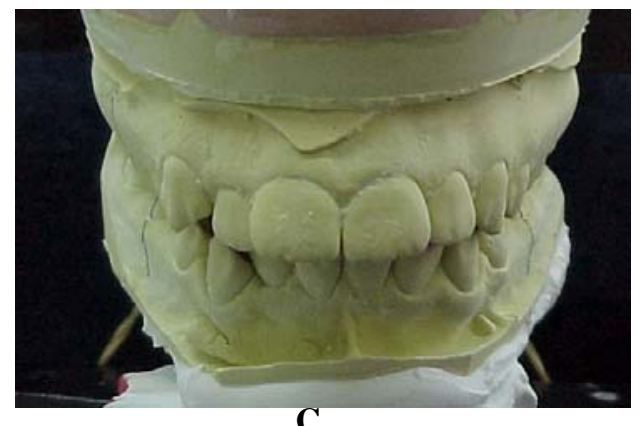

C

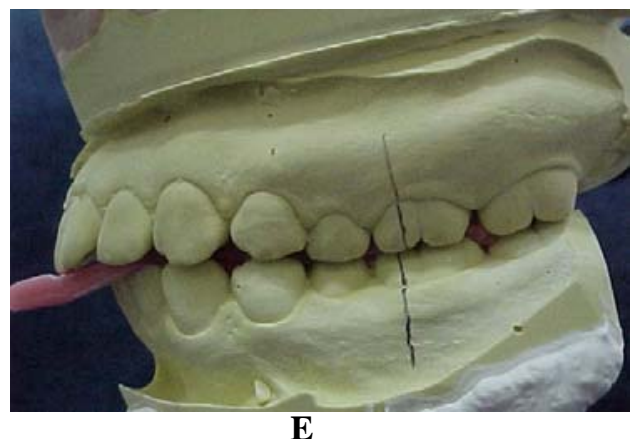

E

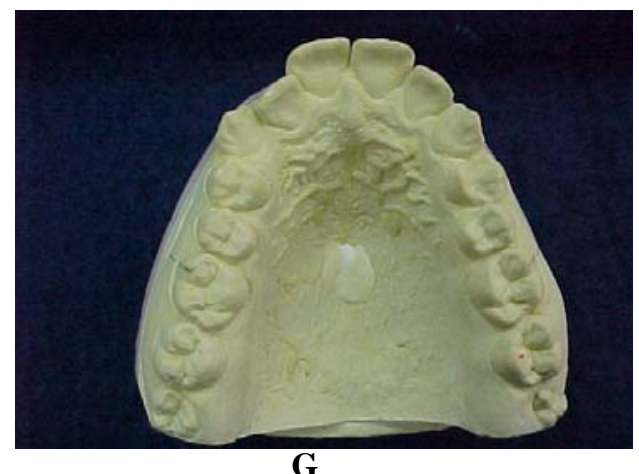

G

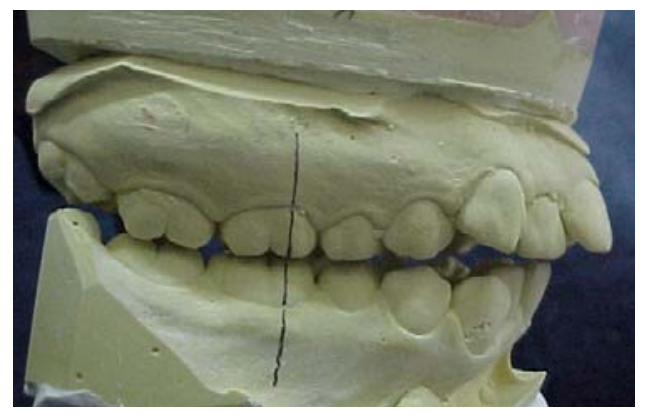

B

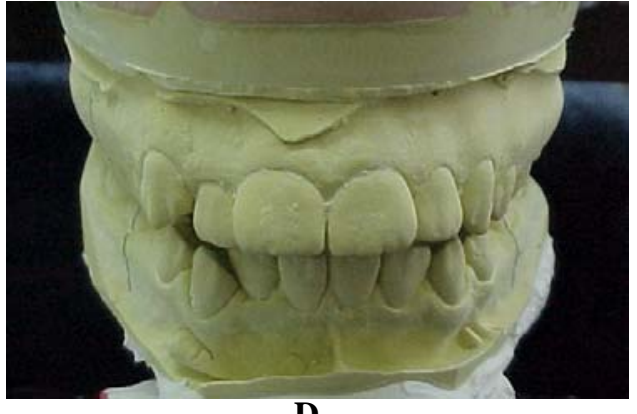

D

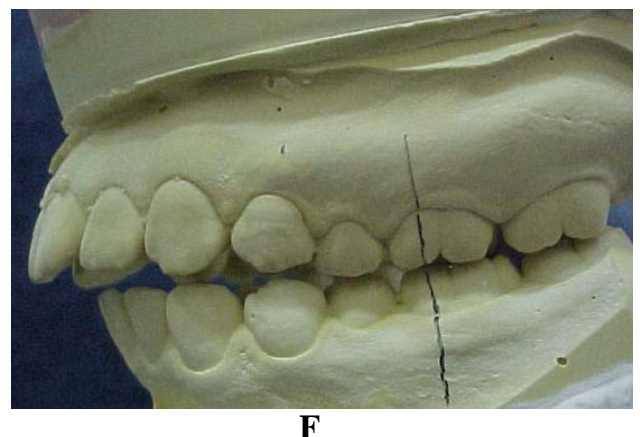

$\mathbf{F}$

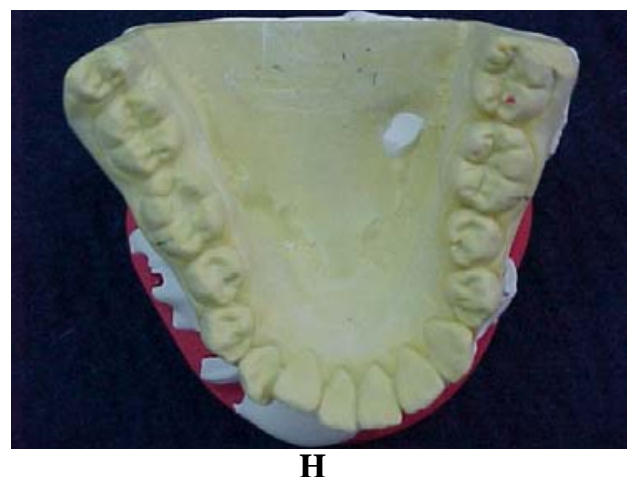

H

Figura 6 - Modelos de paciente do grupo Controle, montados em articulador, vistos em MIC e em RC. A - Vista do lado direito, em MIC. B - Vista do lado direito, em RC. C - Vista frontal, em MIC. D - Vista frontal, em RC. E - Vista do lado esquerdo, em MIC. F - Vista do lado esquerdo, em RC. G - Vista oclusal superior, com o primeiro ponto de contato em RC, marcado em vermelho. $\mathbf{H}$ - Vista oclusal inferior, com o primeiro ponto de contato em RC, marcado em vermelho 
Da mesma forma, os aspectos faciais e dentários dos indivíduos do grupo Experimental, registrados por meio de slides, tanto antes como depois do uso das placas desprogramadoras, confirmam que os pacientes em RC podem apresentar maloclusões, significantemente diferentes, do ponto de vista clínico, daquelas vistas em MIC (Fig. 7-8). Esse fato tem sido intensamente divulgado por Roth (1981a). Segundo ele, as diferenças entre as maloclusões analisadas em RC e MIC podem manifestar-se nos sentidos vertical, horizontal e transversal. Assim, maloclusões de Cl I em MIC, podem revelar-se maloclusões de $\mathrm{Cl}$ II, em RC; maloclusões de $\mathrm{Cl}$ III em MIC podem apresentar-se como maloclusões de $\mathrm{Cl}$ I em RC, e geralmente, as maloclusões de $\mathrm{Cl}$ II em MIC, mostram-se maloclusões de $\mathrm{Cl}$ II mais severas em RC. Pode ser encontrada também, diferença de dimensão da sobremordida anterior que, em geral, diminui em RC. Pode revelar-se ainda, descoordenação transversal entre as arcadas. 


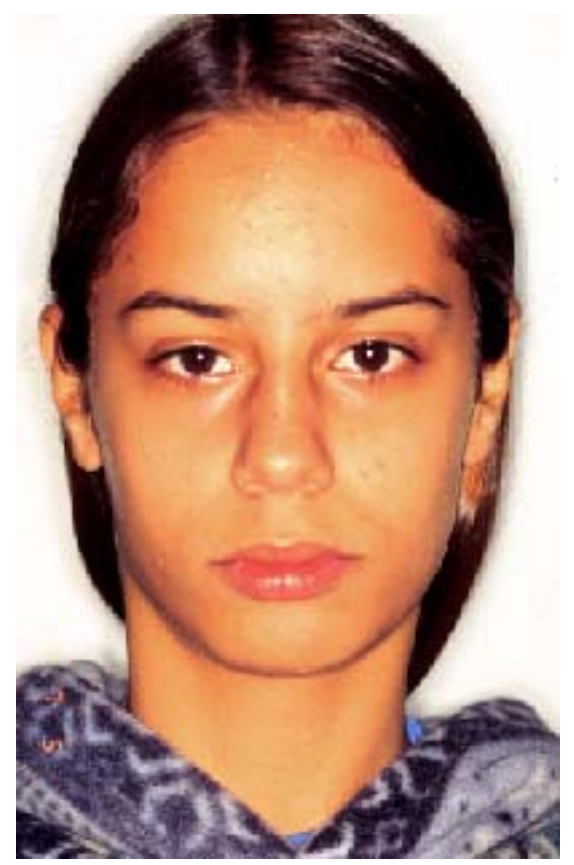

A

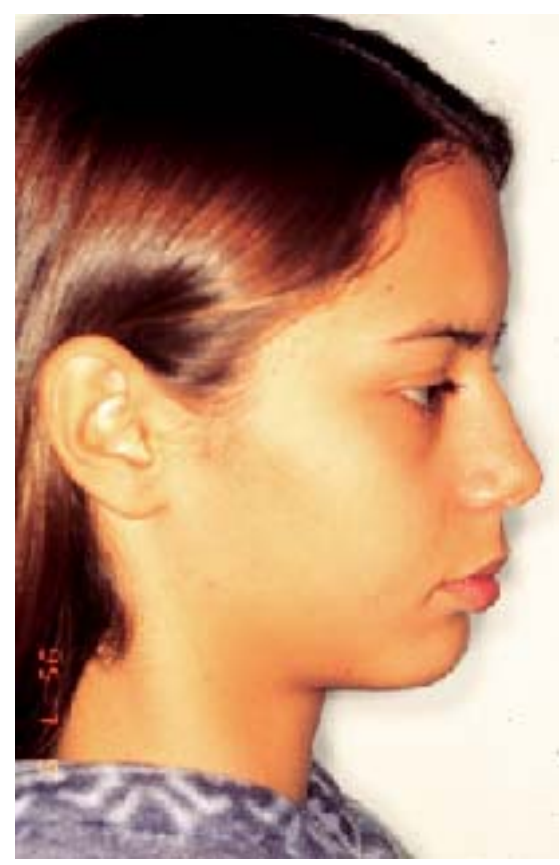

C

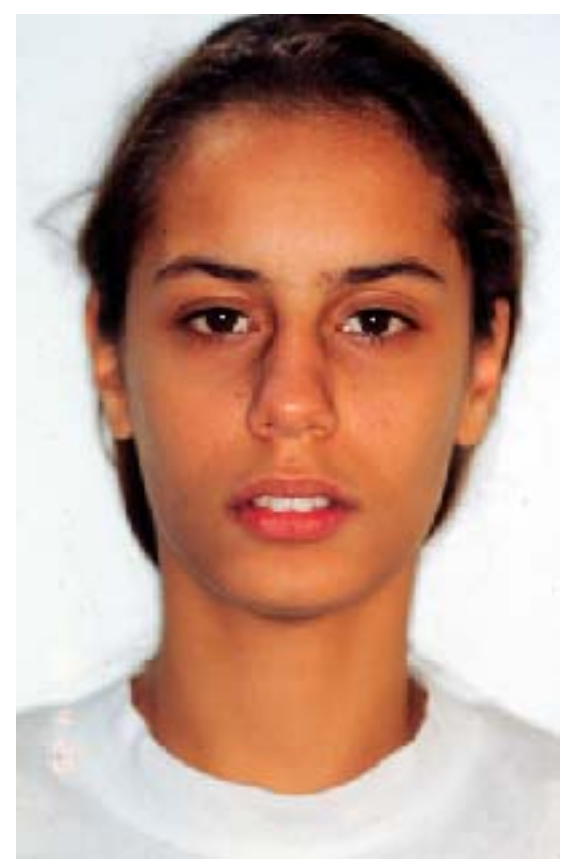

B

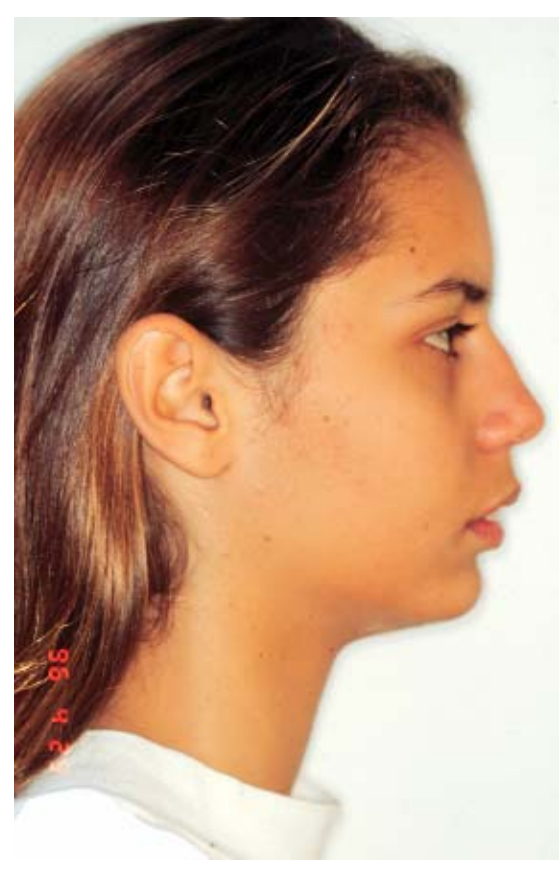

D

Figura 7 - Aspectos faciais de paciente do grupo Experimental, antes (MIC) e após (RC) desprogramação neuromuscular com placa. A - Vista frontal em MIC. B - Vista frontal em RC. C - Vista de perfil em MIC. D - Vista de perfil em RC 


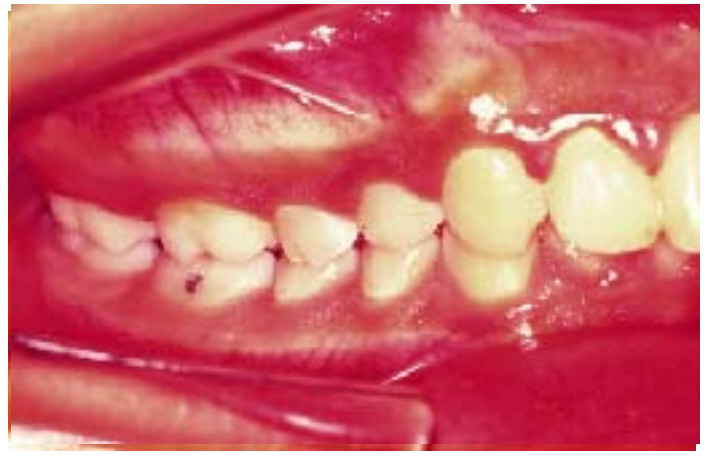

A

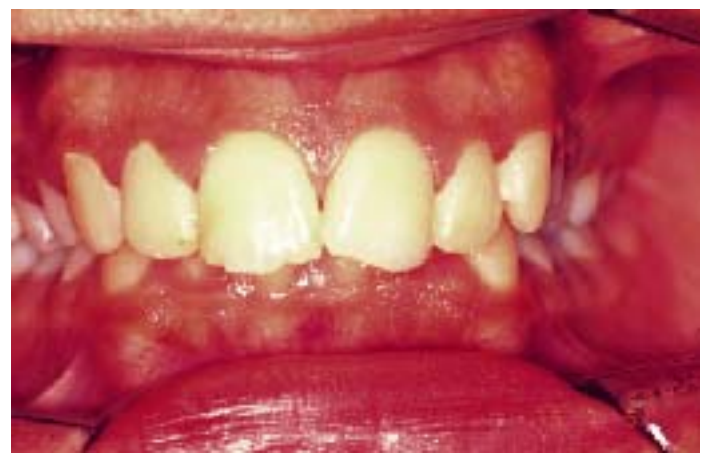

C

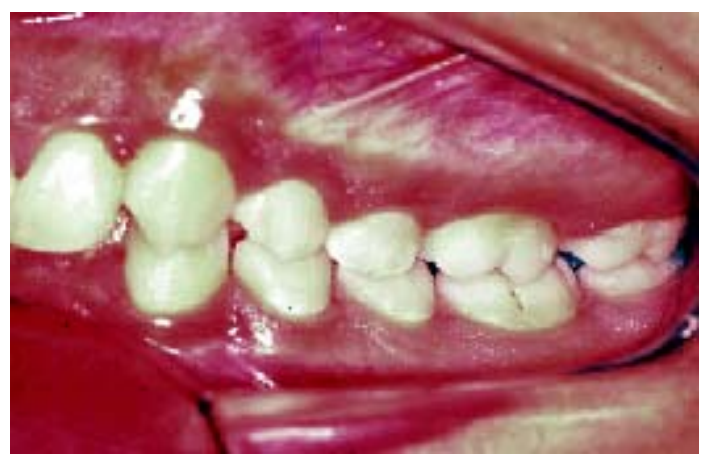

$\mathbf{E}$

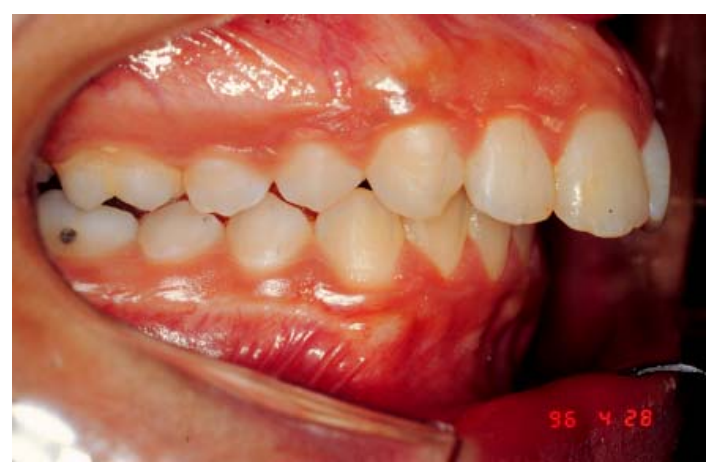

B

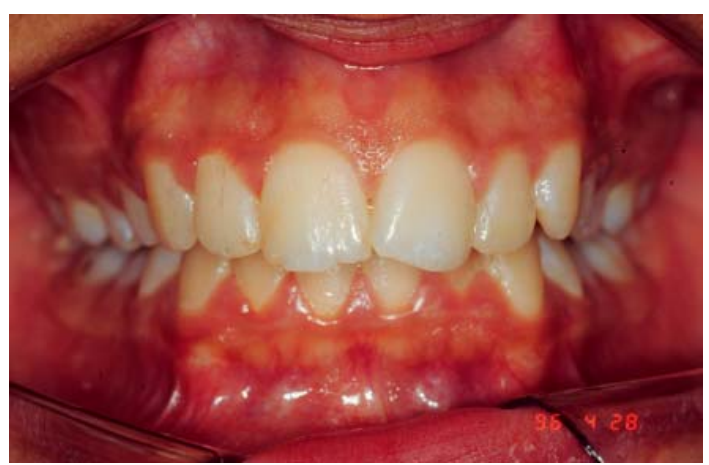

D

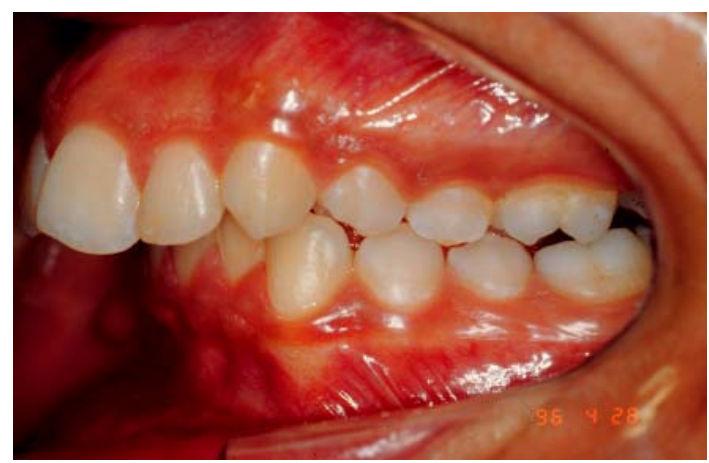

$\mathbf{F}$

Figura 8 - Aspecto intra-bucal de paciente do grupo Experimental, antes (MIC) e após (RC) desprogramação neuromuscular com placa. A - Vista do lado direito em MIC. B - Vista do lado direito em RC. C - Vista de frente em MIC. D - Vista de frente em RC. E - Vista do lado esquerdo em MIC. F - Vista do lado esquerdo em RC 
Também, segundo Roth (1981), a conversão para RC, de telerradiografias laterais da face obtidas em MIC, pode modificar os valores cefalométricos relacionados à mandíbula, especialmente quando os dados do IPC forem maiores que $2 \mathrm{~mm}$, em pelo menos, um dos três planos do espaço.

Em certo número de pacientes, as diferenças entre RC e MIC podem implicar em alteração do plano de tratamento (Chang et al.,1997; Roth, 1981; Utt et al., 1995).

Utt et al. (1995) mencionam que $19 \%$ do total da amostra analisada apresentaram deslocamentos condilares maiores que $2 \mathrm{~mm}$, em pelo menos, uma direção do IPC. Como não encontraram qualquer correlação entre grau de deslocamento e fatores que pudessem identificar os indivíduos com predisposição a maiores deslocamentos, aqueles autores recomendam a montagem dos modelos em articulador, de todos os pacientes a serem tratados, a fim de identificarem-se aqueles com deslocamentos significantes entre RC e MIC.

Chang et al. (1997) descrevem por sua vez, mudança no plano de tratamento ortodôntico, originalmente proposto, após análise dos pacientes em RC, em 3 dos 4 casos apresentados. Os planos de tratamento originais basearam-se em documentação ortodôntica padrão.

No presente estudo, a proporção de casos com deslocamentos condilares entre RC e MIC, iguais ou superiores a $2 \mathrm{~mm}$, no sentido vertical, no grupo Experimental, foi de $81,8 \%$ no lado direito e de $77,3 \%$, no lado 
esquerdo. No grupo Controle, aquelas proporções foram de $26,1 \%$ no lado direito e de $4,3 \%$, no lado esquerdo.

No sentido horizontal, a proporção de casos com deslocamentos condilares iguais ou superiores a $2 \mathrm{~mm}$ foi, no grupo Experimental, de 13,6\% e $31,8 \%$ nos lados direito e esquerdo respectivamente, enquanto que no grupo Controle as proporções foram iguais a 0.

No sentido transversal, a proporção de casos com deslocamento igual ou superior a $2 \mathrm{~mm}$ foi de $4,5 \%$ no grupo Experimental e igual a 0 , no grupo Controle.

Comparando-se os grupos Experimental e Controle, encontrou-se diferença estatísticamente significante em relação à proporção de casos com valores iguais ou superiores a $2 \mathrm{~mm}$ no sentido vertical, nos lados direito e esquerdo ( $P<0,001$ e $P<0,001$, respectivamente) ou seja, as proporções encontradas no grupo Experimental são significantemente maiores do que as do grupo Controle. O mesmo ocorreu ao compararem-se as proporções de casos com deslocamento condilar horizontal do lado esquerdo $(P=$ 0,004), encontradas nos grupos Experimental e Controle. Desta forma, as proporções observadas no grupo Experimental, são significantemente maiores do que as do grupo Controle. No lado direito, não foi encontrada diferença estatisticamente significante $(P=0,109)$ entre as proporções apresentadas pelos grupos estudados, no sentido horizontal.

Nas proporções de deslocamento condilar transversal, não foi encontrada diferença estatisticamente significante entre os grupos analisados $(P=0,489)$. 


\section{CONCLUSÕES}

A análise e a discussão dos resultados obtidos no presente trabalho, permitiram-nos concluir:

7.1- Os deslocamentos condilares entre RC e MIC foram os seguintes: No grupo Experimental:

- No plano vertical: $4,24 \mathrm{~mm}( \pm 2,53)$ no lado direito e $3,86 \mathrm{~mm}( \pm 2,72)$ no lado esquerdo.

- No plano horizontal: $-0,72 \mathrm{~mm}( \pm 1,53)$ no lado direito e de $-0,51 \mathrm{~mm}$ $( \pm 1,98)$ no lado esquerdo.

- No plano transversal: $0,03 \mathrm{~mm}( \pm 0,87)$.

No grupo Controle:

- No plano vertical: $1,31 \mathrm{~mm}( \pm 0,72)$ no lado direito e $1,86 \mathrm{~mm}( \pm 0,64)$ no lado esquerdo

- No plano horizontal: $-0,13 \mathrm{~mm}( \pm 0,66)$ no lado direito e $-0,11 \mathrm{~mm}( \pm 0,73)$ no lado esquerdo

- No plano transversal: $-0,03 \mathrm{~mm}( \pm 0,30)$ 
7.2- Verificou-se diferença estatisticamente significante entre os grupos Experimental e Controle, quando comparados os dados relativos aos deslocamentos condilares entre RC e MIC, nos lados direito e esquerdo, no plano vertical apenas, sendo significantemente maior, no grupo Experimental.

Não se encontrou diferença estatisticamente significante entre os dois grupos estudados, quando comparados os dados do IPC, nos sentidos horizontal e transversal.

7.3.1- Não se observou correlação entre o deslocamento condilar exibido pelo grupo Experimental, nos três planos do espaço, e o tempo de uso da placa desprogramadora.

7.3.2- Identificou-se correlação inversa estatisticamente significante, entre os estágios de maturidade óssea e as medidas de deslocamento vertical dos côndilos direito e esquerdo, no grupo Experimental. Assim, quanto maior a maturidade óssea do paciente, menores os deslocamentos encontrados no sentido vertical.

As correlações encontradas entre o estágio de maturidade óssea e os demais deslocamentos avaliados, não são estatisticamente significantes.

7.3.3- Constatou-se correlação inversa estatisticamente significante, entre idade cronológica e os deslocamentos verticais nos lados direito e 
esquerdo, do grupo Experimental. Desta forma, quanto mais velho o paciente, menores os deslocamentos encontrados, no sentido vertical.

As correlações encontradas entre idade cronológica e os demais deslocamentos avaliados, não são estatisticamente significantes.

7.4 Observou-se diferença estatisticamente significante entre as medidas de deslocamento condilar dos lados direito e esquerdo, apenas no sentido vertical, do grupo Experimental. A medida de deslocamento vertical do lado direito é significantemente maior que do lado esquerdo, naquele grupo.

Não se constatou diferença estatisticamente significante entre as medidas dos deslocamentos horizontais dos lados direito e esquerdo, nos pacientes do grupo Experimental, nem tampouco, entre os deslocamentos verticais e horizontais dos lados direito e esquerdo, no grupo Controle.

7.5 Não se encontraram diferenças estatisticamente significantes entre homens e mulheres, em relação a todos deslocamentos condilares avaliados, tanto no grupo Experimental, como no grupo Controle. 
ANEXOS 
TABELA 1 - Valores originais dos deslocamentos condilares nos sentidos vertical, horizontal e transversal, do grupo Experimental

\begin{tabular}{cccccc}
\hline $\begin{array}{c}\text { Pacientes do } \\
\text { grupo } \\
\text { Experimental } \\
1\end{array}$ & IPC vert D IPC vert E IPC hor D IPC hor E IPC transv \\
\hline 2 & 2,9 & 3,8 & $-0,1$ & $-0,2$ & $-0,1$ \\
\hline 3 & 3,9 & 2,2 & $-1,6$ & 0,1 & $-0,4$ \\
\hline 4 & 7,0 & 5,7 & $-1,7$ & $-1,7$ & $-0,3$ \\
\hline 5 & 9,1 & 8,6 & $-1,5$ & $-2,0$ & 0,3 \\
\hline 6 & 5,1 & 3,7 & 1,3 & 4,0 & $-1,0$ \\
\hline 7 & 6,7 & 7,0 & $-3,7$ & $-3,7$ & 0,5 \\
\hline 8 & 9,3 & 7,8 & $-1,4$ & $-1,3$ & $-0,7$ \\
\hline 9 & 1,4 & 0,7 & 0,6 & 0,2 & 0,6 \\
\hline 10 & 2,8 & 2,2 & 1,5 & $-0,3$ & 1,0 \\
\hline 11 & 8,1 & 8,7 & 1,4 & 1,8 & $-0,7$ \\
\hline 12 & 5,9 & 8,5 & $-3,4$ & $-3,8$ & $-0,2$ \\
\hline 13 & 2,5 & 2,3 & 0,5 & 0,4 & 1,1 \\
\hline 14 & 2,8 & 1,5 & $-1,3$ & 1,4 & $-0,3$ \\
\hline 15 & 1,3 & 0,9 & $-0,7$ & $-0,4$ & 0,0 \\
\hline 16 & 1,2 & 0,2 & 0,9 & 1,6 & $-0,4$ \\
\hline 17 & 1,7 & 1,4 & $-1,0$ & $-0,8$ & 0,0 \\
\hline 18 & 2,7 & 2,3 & $-0,7$ & 2,0 & $-0,5$ \\
\hline 19 & 3,6 & 3,3 & $-1,5$ & $-3,5$ & 1,0 \\
\hline 20 & 2,8 & 3,0 & $-3,0$ & $-1,7$ & $-1,7$ \\
\hline 21 & 5,9 & 5,3 & $-0,2$ & $-2,7$ & 2,1 \\
\hline 22 & 4,3 & 3,2 & $-1,4$ & $-0,7$ & $-0,8$ \\
\hline & 2,2 & 2,5 & 1,2 & 0,0 & 1,1 \\
\hline
\end{tabular}


TABELA 2 - Valores dos deslocamentos condilares no sentido vertical, do grupo Experimental, corrigidos pelas variáveis idade cronológica e estágio de maturidade esquelética

\begin{tabular}{|c|c|c|}
\hline $\begin{array}{l}\text { Pacientes do grupo } \\
\text { Experimental }\end{array}$ & $\begin{array}{l}\text { IPC vert D } \\
\text { corrigido }\end{array}$ & IPC vert E corrigido \\
\hline 1 & 4,9183 & 4,68234 \\
\hline 2 & 4,4488 & 3,80934 \\
\hline 3 & 4,0545 & 3,389 \\
\hline 4 & 6,1593 & 6,18084 \\
\hline 5 & 7,6155 & 7,17875 \\
\hline 6 & 6,3315 & 6,2745 \\
\hline 7 & 6,995 & 6,4295 \\
\hline 8 & 3,0507 & 3,04891 \\
\hline 9 & 2,5272 & 1,94066 \\
\hline 10 & 5,2743 & 4,67009 \\
\hline 11 & 3,9575 & 3,748 \\
\hline 12 & 3,7853 & 3,65434 \\
\hline 13 & 1,9778 & 1,64184 \\
\hline 14 & 1,4325 & 1,34525 \\
\hline 15 & 2,0147 & 1,66191 \\
\hline 16 & 2,1172 & 1,71766 \\
\hline 17 & 5,2743 & 4,67009 \\
\hline 18 & 5,1663 & 4,19959 \\
\hline 19 & 4,265 & 3,91525 \\
\hline 20 & 6,639 & 6,44175 \\
\hline 21 & 2,614 & 2,19375 \\
\hline 22 & 2,7124 & 2,24727 \\
\hline
\end{tabular}


TABELA 3 - Valores dos deslocamentos condilares nos sentidos vertical, horizontal e transversal, do grupo Controle

Pacientes do IPC vert D IPC vert E IPC hor D IPC hor E IPC transv grupo Controle

\begin{tabular}{|c|c|c|c|c|c|}
\hline 1 & 0,3 & 0,1 & 1,3 & 1,0 & 0,0 \\
\hline 2 & 0,7 & 0,2 & 0,3 & 0,9 & $-0,8$ \\
\hline 3 & 2,0 & 1,9 & 0,3 & 0,3 & $-0,3$ \\
\hline 4 & 1,5 & 1,3 & $-0,8$ & $-0,1$ & $-0,2$ \\
\hline 5 & 1,0 & 0,6 & 0,4 & 0,2 & 0,0 \\
\hline 6 & 0,7 & 0,6 & 0,2 & 1,3 & $-0,1$ \\
\hline 7 & 2,2 & 1,9 & $-1,0$ & $-0,8$ & 0,4 \\
\hline 8 & 1,8 & 1,2 & $-0,6$ & $-1,0$ & $-0,1$ \\
\hline 9 & 0,5 & 1,0 & 0,4 & 0,0 & 0,3 \\
\hline 10 & 1,1 & 0,6 & 0,0 & 0,5 & $-0,3$ \\
\hline 11 & 2,2 & 1,9 & $-0,6$ & $-1,3$ & 0,4 \\
\hline 12 & 1,9 & 0,6 & $-0,8$ & 0,4 & $-0,4$ \\
\hline 13 & 1,8 & 1,7 & 0,7 & 0,3 & 0,2 \\
\hline 14 & 2,2 & 1,3 & $-0,8$ & $-0,9$ & $-0,3$ \\
\hline 15 & 1,0 & 1,2 & $-0,5$ & $-1,1$ & 0,1 \\
\hline 16 & 0,1 & 0,5 & 0,7 & 0,3 & 0,0 \\
\hline 17 & 1,1 & 1,4 & $-0,8$ & $-1,0$ & $-0,1$ \\
\hline 18 & 0,7 & 0,9 & 0,5 & $-0,3$ & 0,4 \\
\hline 19 & 1,3 & 1,4 & $-0,1$ & $-0,7$ & 0,2 \\
\hline 20 & 2,2 & 0,8 & $-0,3$ & 0,5 & $-0,2$ \\
\hline 21 & 2,5 & 2,5 & $-1,3$ & $-0,2$ & $-0,2$ \\
\hline 22 & 0,9 & 1,3 & 0,2 & $-0,7$ & 0,4 \\
\hline 23 & 0,4 & 0,0 & $-0,5$ & $-0,2$ & $-0,2$ \\
\hline
\end{tabular}


TABELA 4 - Idades cronológicas e índices de maturidade esquelética do grupo Experimental, ao início e ao término do uso das placas desprogramadoras.

\begin{tabular}{ccccc}
\hline $\begin{array}{c}\text { Pacientes do } \\
\text { grupo } \\
\text { Experimental }\end{array}$ & $\begin{array}{c}\text { Idade ao início } \\
\text { do uso das } \\
\text { placas }\end{array}$ & $\begin{array}{c}\text { Idade ao final do } \\
\text { uso das placas }\end{array}$ & $\begin{array}{c}\text { Maturidade } \\
\text { esquelética ao } \\
\text { ińcio do uso } \\
\text { das placas }\end{array}$ & $\begin{array}{c}\text { Maturidade } \\
\text { esquelética ao } \\
\text { final do uso das } \\
\text { placas }\end{array}$ \\
\hline 1 & $14 a 5 \mathrm{~m}$ & $14 \mathrm{a} 11 \mathrm{~m}$ & 6,5 & 7,5 \\
\hline 2 & $13^{\mathrm{a}}$ & $13 \mathrm{a} 5 \mathrm{~m}$ & 8 & 9 \\
\hline 3 & $12 \mathrm{a} 11 \mathrm{~m}$ & $13 \mathrm{a} 6 \mathrm{~m}$ & 9 & 9,5 \\
\hline 4 & $15^{\mathrm{a}}$ & $15 \mathrm{a} 5 \mathrm{~m}$ & 5 & 5,5 \\
\hline 5 & $12^{\mathrm{a}}$ & $12 \mathrm{a} 9 \mathrm{~m}$ & 4 & 5 \\
\hline 6 & $14 \mathrm{a} 6 \mathrm{~m}$ & $15 \mathrm{a}$ & 5 & 5,5 \\
\hline 7 & $12 \mathrm{a} 1 \mathrm{~m}$ & $12 \mathrm{a} 6 \mathrm{~m}$ & 5 & 6 \\
\hline 8 & $15 \mathrm{a} 11 \mathrm{~m}$ & $16 \mathrm{a} 10 \mathrm{~m}$ & 7,5 & 9 \\
\hline 9 & $13 \mathrm{a} 8 \mathrm{~m}$ & $14 \mathrm{a} 7 \mathrm{~m}$ & 10,5 & 11 \\
\hline 10 & $12 \mathrm{a} 7 \mathrm{~m}$ & $13 \mathrm{a} 2 \mathrm{~m}$ & 7 & 8 \\
\hline 11 & $14 \mathrm{a} 8 \mathrm{~m}$ & $15 \mathrm{a} 6 \mathrm{~m}$ & 7,5 & 8,5 \\
\hline 12 & $15 \mathrm{a} 5 \mathrm{~m}$ & $15 \mathrm{a} 11 \mathrm{~m}$ & 8,0 & 8,5 \\
\hline 13 & $15 \mathrm{a} 5 \mathrm{~m}$ & $15 \mathrm{a} 11 \mathrm{~m}$ & 10,5 & 11 \\
\hline 14 & $16 \mathrm{a} 9 \mathrm{~m}$ & $17 \mathrm{a} 3 \mathrm{~m}$ & 11 & 11 \\
\hline 15 & $15 \mathrm{a} 2 \mathrm{~m}$ & $15 \mathrm{a} 10 \mathrm{~m}$ & 11 & 11 \\
\hline 16 & $15 \mathrm{a} 1 \mathrm{~m}$ & $15 \mathrm{a} 7 \mathrm{~m}$ & 11 & 11 \\
\hline 17 & $12 \mathrm{a} 7 \mathrm{~m}$ & $13 \mathrm{a} 2 \mathrm{~m}$ & - & - \\
\hline 18 & $11 \mathrm{a} 2 \mathrm{~m}$ & $11 \mathrm{a} 8 \mathrm{~m}$ & 8 & 9 \\
\hline 19 & $14 \mathrm{a} 3 \mathrm{~m}$ & $14 \mathrm{a} 9 \mathrm{~m}$ & 8 & 8,5 \\
\hline 20 & $13 \mathrm{a} 4 \mathrm{~m}$ & $14 \mathrm{a} 3 \mathrm{~m}$ & 5 & 5,5 \\
\hline 21 & $14 a 5 \mathrm{~m}$ & $15 \mathrm{a} 3 \mathrm{~m}$ & 10 & 10,5 \\
\hline 22 & $14 a 9 \mathrm{~m}$ & $15 \mathrm{a} 1 \mathrm{~m}$ & 10,5 & 10,5 \\
\hline
\end{tabular}


TABELA 5 - Idades cronológicas e índices de maturidade esquelética do grupo Controle

\begin{tabular}{|c|c|c|}
\hline Pacientes do grupo Controle & $\begin{array}{c}\text { Idade } \\
\text { cronológi } \\
\text { ca }\end{array}$ & $\begin{array}{l}\text { Maturidade } \\
\text { esquelética }\end{array}$ \\
\hline 1 & 19a8m & 11 \\
\hline 2 & $16 a 4 m$ & 10 \\
\hline 3 & 14a9m & 11 \\
\hline 4 & $16 a 3 m$ & 11 \\
\hline 5 & $15 \mathrm{a} 7 \mathrm{~m}$ & 9 \\
\hline 6 & $16 a$ & 11 \\
\hline 7 & $19 a 2 m$ & 11 \\
\hline 8 & $18 \mathrm{a} 5 \mathrm{~m}$ & 11 \\
\hline 9 & $16 a 9 m$ & 11 \\
\hline 10 & 17a10m & 11 \\
\hline 11 & $17 \mathrm{a} 6 \mathrm{~m}$ & 11 \\
\hline 12 & $15 a 2 m$ & 10 \\
\hline 13 & $16 a 3 m$ & 11 \\
\hline 14 & $15 a 11 \mathrm{~m}$ & 11 \\
\hline 15 & $17 \mathrm{a} 3 \mathrm{~m}$ & 11 \\
\hline 16 & $18 a 8 m$ & 11 \\
\hline 17 & $16 a 11 \mathrm{~m}$ & 11 \\
\hline 18 & $15 a 3 m$ & 11 \\
\hline 19 & $15 a 2 m$ & 7 \\
\hline 20 & $17 \mathrm{a} 1 \mathrm{~m}$ & 7 \\
\hline 21 & 14a10m & 10 \\
\hline 22 & $15 a 10 m$ & 10 \\
\hline 23 & $16 a 11 \mathrm{~m}$ & 11 \\
\hline
\end{tabular}


TABELA 6 - Tempo de uso das placas desprogramadoras, no grupo Experimental

\begin{tabular}{|c|c|}
\hline $\begin{array}{l}\text { Pacientes do grupo } \\
\text { Experimental }\end{array}$ & $\begin{array}{c}\text { Tempo de uso da placa } \\
\text { desprogramadora }\end{array}$ \\
\hline 1 & $6 \mathrm{~m} 13 \mathrm{~d}$ \\
\hline 2 & $5 \mathrm{~m} 16 \mathrm{~d}$ \\
\hline 3 & $7 m 4 d$ \\
\hline 4 & $5 m 24 d$ \\
\hline 5 & $9 m 26 d$ \\
\hline 6 & $6 m 7 d$ \\
\hline 7 & $5 \mathrm{~m} 26 \mathrm{~d}$ \\
\hline 8 & $11 \mathrm{~m} 17 \mathrm{~d}$ \\
\hline 9 & $11 \mathrm{~m} 28 \mathrm{~d}$ \\
\hline 10 & $7 \mathrm{~m} 18 \mathrm{~d}$ \\
\hline 11 & $10 \mathrm{~m} 17 \mathrm{~d}$ \\
\hline 12 & $6 m 20 d$ \\
\hline 13 & $6 m 13 d$ \\
\hline 14 & $6 m 26 d$ \\
\hline 15 & $8 m 15 d$ \\
\hline 16 & $6 m 28 d$ \\
\hline 17 & $7 m 4 d$ \\
\hline 18 & $6 m 27 d$ \\
\hline 19 & $6 m 6 d$ \\
\hline 20 & $11 \mathrm{~m}$ \\
\hline 21 & $10 \mathrm{~m} 5 \mathrm{~d}$ \\
\hline 22 & $4 m 23 d$ \\
\hline
\end{tabular}




\section{REFERÊNCIAS BIBLIOGRÁFICAS *}

1. ABRÃO, J. Análise oclusal em pacientes ao término do tratamento ortodôntico empregando-se a técnica do arco de canto. São Paulo, 1991. 203p. Tese (Doutorado em Ortodontia) - Faculdade de Odontologia da Universidade de São Paulo.

2. THE ACADEMY OF DENTURE PROSTHETICS. Glossary of prosthodontic terms. 5.ed. St. Louis: Mosby, 1987.

3. AHLGREN, J.; POSSELT, U. Need of functional analysis and selective grinding in orthodontics. A clinical and eletromyographic study. Acta Odontol Scand, v.21, n.3, p.187-208, June 1963.

4. ALEXANDER, S.R.; MOORE, R.N.; DUBOIS, L.M. Mandibular condyle position: comparison of articular mountings and magnetic resonance imaging. Am J Orthod Dentofac Orthop, vol.104, no.3, p. 230-239, Sept. 1995.

\footnotetext{
* De acordo com NBR-6023 da Associação Brasileira de Normas Técnicas, 1989. Abreviatura de periódicos segundo "Index to Dental Literature".
} 
5. ANGLE, E.H. Classification of malocclusion. Dent Cosmos, v.41, n.2, p.248-264, Feb. 1899.

6. ARAÚJO, C.R.P.; PANDOLFI, R.F.; BONACHELA, V.; FERREIRA, P.M. Estudo comparativo de duas metodologias para registro da relação cêntrica. Rev Odontol Univ São Paulo, v.2, n.2, p.73-76, apr./jun. 1988.

7. ARNETT, G.W.; BERGMAN, R.T. Facial keys to orthodontic diagnosis and treatment planning. Part I. Am J Orthod Dentofac Orthop, v.103, n.4, p. 299-312, Apr. 1993.

8. ARNETT, G.W.; TAMBORELLO, J.A. Progressive class II development. Female idiopathic condylar resorption. Oral Maxillofac Surg Clin, v.2, n.4, p. 699-716, Nov. 1990.

9. ARNETT, G.W.; MILAN, S.B.; GOTTESMAN, L. Progresssive mandibular retrusion- idiopathic condylar resorption. Part I. Am J Orthod Dentofac Orthop, v.110, n.1, p.8-15, July 1996a.

10. ARNETT, G.W.; MILAN, S.B.; GOTTESMAN, L. Progresssive mandibular retrusion- idiopathic condylar resorption. Part II. Am J Orthod Dentofac Orthop, v.110, n.2, p.117-127, Aug. 1996b. 
11. AUBREY, R.B. Occlusal objetives in orthodontic treatment. Am $\mathbf{J}$ Orthod, v.74, n.2, p.162-175, Aug. 1978.

12. BASIC articulation system: instruction manual. Grand Terrace: Panadent, 1985. 60p.

13. BASICS of occlusion. Adept Report, v.4, n.1/2, p.1-16, Winter/Spring 1993.

14. BEARD, C.C.; CLAYTON, J.A. Effects of occlusal therapy on temporomandibular joint dysfunction. J Prosthet Dent, v.44, n.3, p.324- 335, Sept. 1980.

15. BECKER, C.M.; KAISER, D.A. Evolution of occlusion and occlusion instruments. J Prosthet Dent, v.2, n.1, p.33-43, Mar. 1993.

16. BEYRON, H.L. Characteristics of functionally optimal occlusion and principles of occlusal rehabilitation. J Am Dent Assoc, v. 48, n.6, p.648-656, June 1954.

17. CALAGNA, L.J.; SILVERMAN, S.I.; GARFINKEL, L. Influence of neuromuscular conditioning on centric relation registrations. J Prosthet Dent, v.30, n.4, p.598-606, Oct. 1973. 
18. CAPP, N.J.; CLAYTON, J.A. A technique for evaluation of centric relation tooth contacts. Part I: during normal temporomandibular joint function. J Prosthet Dent, v.54, n.4, p.569-574, Oct. 1985a.

19. CAPP, N.J.; CLAYTON, J.A. A technique for evaluation of centric relation tooth contacts. Part II: following use of na occlusal splint for treatment of temporomandibular joint dysfunction. J Prosthet Dent, v.54, n.5, p.697-705, Nov. 1985b.

20. CARLSON, N.; MOLINE, D.; HUBER, L.; JACOBSON, J. Comparison of muscle activity between conventional and neuromuscular splints. J Prosthet Dent, v.70, n.1, p.39-43, July 1993.

21. CELENZA, F.V. Position paper. In: CELENZA, F.V.; NASEDKIN, J.N. Occlusion, the state of the art. Chicago: Quintessence, 1978. p.31-41.

22. CHANG, F.H.F.; CHEN, K.; SHIAN, Y. The importance of determination of jaw position in orthodontic diagnosis and treatment planning for adult patients. Dent Clin North Am, v.4, n.1, p.49-66, Jan. 1997.

23. CHIAPPONE, R.C. A gnathologic approach to orthodontic finishing. $\mathbf{J}$ Clin Orthod, v.9, n.7, p.405-417, July 1975.

24. CONTIN, I. Estudo comparativo do reposicionamento mandibular (MIC-RC), frente ao uso do Jig e do uso da placa mio-relaxante 
em pacientes dentados assintomáticos e com dor miofacial da cabeça e pescoço. São Paulo, 1997. 106p. Tese (Doutorado em Prótese Parcial Fixa) - Faculdade de Odontologia da Universidade de São Paulo.

25. CRISPIN, B.J.; MYERS, G.E.; CLAYTON, J.A. Effects of occlusal therapy on pantographic reproducibility of mandibular border movements. J Prosthet Dent, v.40, n.1, p.29- 34, July 1978.

26. DAWSON, P.E. A classification system for occlusions that relates maximal intercuspation to the position and condition of the temporomadibular joints. J Prosthet Dent, v.75, n.1, p.60-66, Jan. 1996.

27. DAWSON, P.E. Evaluation, diagnosis and treatment of occlusal problems. St. Louis: Mosby, 1974. 407p.

28. DAWSON, P. E. New definition for relating occlusion to varying conditions of the temporomandibular joint. J Prosthet Dent, v.74, n.6, p.619-627, Dec. 1995.

29. DAWSON, P.E. Position paper. In: CELENZA, F.V.; NASEDKIN, J.N. Occlusion, the state of the art. Chicago: Quintessence, 1978. p.47-55. 
30. DAWSON, P.E. Temporomandibular joint pain-dysfunction problems can be solved. J Prosthet Dent, v.29, n.1, p.100-112, Jan. 1973.

31. De BOEVER, J.A.; ADRIAENS, P.A. Occlusal relationship in patients with pain-dysfunction symptoms in the temporomandibular joints. $\mathbf{J}$ Oral Rehabil, v.10, n.1, p.1-7, Jan. 1988.

32. De LAAT, A.; VAN STEENBERG, D.; LeSAFFRE, E. Occlusal relationship and temporomandibular joint dysfunction. Part II: correlations between occlusal and articular parameters and symptoms of TMJ dysfunction by means of stepwise logistic regression. J Prosthet Dent, v.55, n.1, p.116-121, Jan. 1986.

33. DUPAS, P.H.; PICART, B.; LEFREVE, C.; GRAUX, F. Centric relation and programming semiajustable articulators with the universal jig. Part I: technique. J Prosthet Dent, v.64, n.2, p.134-138, Aug. 1990.

34. DYER, E. H. Importance of a stable maxillomandibular relation. J Prosthet Dent, v.30, n.3, p.241-251, Sept. 1973.

35. EGERMARK-ERIKSSON, I.; INGERVALL, B.; CARLSSON, G. E. The dependence of mandibular dysfunction in children on functional and morphologic malocclusion. Am J Orthod, v.83, n.3, p.187-194, Mar. 1983. 
36. FISHMAN, L.S. Radiographic evaluation of skeletal maturation. A clinically oriented method on hand wrist film. Angle Orthod, v.52, n. 2, p.88-112, Apr. 1982.

37. GAITHER, E.L.; SADOWSKY, P.L.; VLACHOS, C.C.; WALLACE, D.D. Discrepancies between centric occlusion and centric relation in orthodontically treated patients. Int $\mathbf{J}$ Adult Orthod Orthognath Surg, v.12, n.1, p. 23-33, 1997.

38. GEERING, A.H. Occlusal interferences and functional disturbances of the masticatory system. J Clin Periodontol, v.1, n.2, p. 112-119, 1974.

39. GILBOE, D.B. Centric relation as the treatment position. J Prosthet Dent, v.50, n.5, p.685-689, Nov. 1983.

40. GOHARIAN, R. K.; NEFF, P. A. Effect of occlusal retainers on temporomandibular joint and facial pain. J Prosthet Dent, v.44, n.2, p.206-208, Aug. 1980.

41. GREENE, C.S. Orthodontics and temporomandibular disorders. Dent Clin North Am, v.32, n.3, p.529-538, July 1988. 
42. GUICHET, N. F. Position paper. In: CELENZA, F.V.; NASEDKIN, J.N. Occlusion, the state of the art. Chicago: Quintessence, 1978. p.77-89.

43. GYSI, A. The problem of articulation. Dent Cosmos, v.52, n.1, p.1-19, 1910a.

44. GYSI, A. The problem of articulation. Dent Cosmos, v.52, n.2, p.148$169,1910 b$

45. HELKIMO, M. Studies on function and dysfunction of the masticatory system. II. Index for anamnestic and clinical dysfunction and occlusal state. Sven Tandlak Tidskr, v.67, n.2, p.101-119, Mar. 1974.

46. HOBO, S.; IWATA, T. Reproducibility of mandibular centricity in three dimensions. J Prosthet Dent, v.53, n.5, p.649-654, May 1985.

47. HOFFMAN, P.J.; SILVERMAN, S.I.; GARFINKEL, L. Comparison of condilar position in centric relation and in centric occlusion in dentulous subjects. J Prosthet Dent, v.30, n.4, p.582-588, Oct. 1973. 
48. IDE, Y.; NAKAZAWA, K. Anatomical atlas of the temporomandibular joint. Tokyo: Qintessence, 1991. 116p.

49. INGERVALL, B. Control of the quality of the occlusal position in orthodontic treatment. Swed Dent J, v.15, p.105-108, 1982. Suplemento.

50. INGERVALL, B.; MOHLIN, B; THILANDER, B. Prevalence of symptoms of functional disturbances of the masticatory system in Swedish men. J Oral Rehabil, v.7, n.3, p.185-197, May 1980.

51. JARABAK, J.R. An eletromyographic analysis of muscular and temporomandibular joint disturbances due to imbalances in occlusion. Angle Orthod, v.26, n.3, p.170-190, July 1956.

52. JOHNSTON Jr., L.E. Gnatologic assessment of centric slides in postretention orthodontic patients. J Prosthet Dent, v.60, n.6, p.712-715, Dec. 1988.

53. KAMPE, T.; HANNERZ, H. Five-year longitudinal study of adolescents with intact and restored dentitions: signs and symptoms of temporomandibular dysfunction and functional recordings. J Oral Rehabil, v.18, n.5, p.387-398, Sept. 1991. 
54. KANTOR, M.E., SILVERMAN S.I., GARFINKEL, L. Centric-relation recording techniques - a comparative investigation. J Prosthet Dent, v.30, n.4, p. 604-606, Oct. 1973.

55. KINDERKNECHT, K.E.; WONG, G.K.; BILLY, E.J.; LI, S.H. The effect of a deprogrammer on the position of the terminal transverse horizontal axis of the mandible. J Prosthet Dent, v.68, n.1, p.123131, July 1992.

56. KOYANO, K.; OGAWA,T.; SUMIYOSHI,K.; TSUKIYAMA,Y.; ICHIKI,R.; SUETSUGU,T. Effect of occlusal splint on masticatory movement in healthy individuals. J Craniomandibular Pract, v.15,n.2, p.127131, Apr. 1997.

57. KOVALESKI, W.C.; DE BOEVER, J. Influence of occlusal splints on jaw position and musculature in patients with temporomandibular joint dysfunction. J Prosthet Dent, v.33, n.3, p.321-327, Mar. 1975.

58. LAURITZEN, A. Atlas of occlusal analysis. Chicago: HAH, 1974. 235p.

59. LONG, J.H. Location of the terminal hinge axis by intraoral means. J Prosthet Dent, v.23, n.1, p.11-24, Jan. 1970. 
60. LONG, J.H; BUHNER, W.A. New diagnostic and terapeutic mechanical device. J Prosthet Dent, v.68, n.5, p.824-828, Nov. 1992.

61. LUCIA, V. O. A techinque of recording centric relation. J Prosthet Dent, v.14, n.3, p.492-505, May/June 1964.

62. LUTHER, F. Orthodontics and the temporomandibular joint: where are we now? Part 2. Functional occlusion, malocclusion, and TMD. Angle Orthod, v.68, n.4, p.305-318, Aug. 1998.

63. McCOLLUM, B.B. Fundamentals involved in prescribing restorative dental remedies. Dent Items Interest, v.61, n.6, p.522-535, June 1939a.

64. McCOLLUM, B.B. Fundamentals involved in prescribing restorative dental remedies. Dent Items Interest, v.61, n.7, p.641-648, July 1939b.

65. McNAMARA Jr., J.A.; SELIGMAN, D.A.; OKESON, J.P. Occlusion, orthodontic treatment, and temporomandibular disorders: a review. Orofac Pain, v.9, n.1, p.73-90, Winter 1995.

66. MILOSEVIC, A.; SAMUELS, R.H. Functional occlusion after fixed appliance orthodontic treatment: a UK three-centre study. Eur J Orthod, v.20, n.5, p.561-568, Oct. 1998. 
67. MOFFETT, B. Position paper. In: CELENZA, F.V.; NASEDKIN, J.N. Occlusion, the state of the art. Chicago: Quintessence, 1978. p.13-18.

68. NEFF, P. Trauma from occlusion. Restorative concerns. Dent Clin North Am, v.39, n.2, p.335-354, Apr. 1995.

69. NELSON, S.J. Principles of stabilization bite splint therapy. Dent Clin North Am, v.39, n.2, p.403-421, Apr. 1995.

70. OKESON, J.P. Fundamentals of occlusion and temporomandibular disorders. 2.ed. St. Louis: Mosby, 1989. p.399-411.

71. OKESON, J.P. Management of temporomandibular disorders and occlusion. 4.ed. St. Louis: Mosby, 1998. 638p.

72. PARKER, M.W. The significance of occlusion in restorative dentistry. Dent Clin, v.37, n.3, p.341-351, July 1993.

73. PARKER, W.S. Centric relation and centric occlusion- an orthodontic responsibility. Am J Orthod, v.74, n.5, p.482-500, Nov. 1978. 
74. PERRY, H.T. Facial, cranial and cervical pain associated with dysfunction of the occlusion and articulation of the teeth. Angle Orthod, v.26, n.3, p.121-143, July 1956.

75. POSSELT, U. Studies in the mobility of the human mandible. Acta Odontol Scand, v.10, p.19-150, 1952. Suplemento.

76. PULLINGER, A.G.; HOLLENDER, L.; SOLBERG, W.K.; PETERSSON, A. A tomographic study of mandibular condyle position in an asymptomatic population. J Prosthet Dent, v.53, n.5, p.706-713, May 1985.

77. PUlLiNGER, A.G.; SOlBERG, W.K.; HOLLENDER, L.; GUICHET, D. Tomographic analysis of mandibular condyle position in diagnostic subgroups of temporomandibular disorders. J Prosthet Dent, v.55, n.6, p.723-729, June 1986.

78. PULLINGER, A.G.; SOLBERG, W.K.; HOLLENDER, L.; PETERSSON, A. Relationship of mandibular condylar position to dental occlusion factors in an asymptomatic population. Am J Orthod Dentofac Orthop, v.91, n.3, p.200-206, Mar. 1987. 
79. RAMFJORD, S.P. Position paper. In: CELENZA, F.V.; NASEDKIN, J.N. Occlusion, the state of the art. Chicago: Quintessence, 1978. p.107-114.

80. RAMFJORD, S.P.; ASH, M.M. Oclusão. Trad. de Dioracy Fonterrada Vieira. 3.ed Rio de Janeiro: Interamericana, 1984. 422p.

81. RANDOW, K.; CARLSSON, K.; EDLUND, J.; OBERG, T. The effect of an occlusal interference on the masticatory system. An experimental investigation. Odontol Revy, v.27, n.4, p.245-255, 1976.

82. RICKETTS, R.M. Abnormal function of the temporomandibular joint. Am J Orthod, v.41, n.6, p.435-441, 1955.

83. RICKETTS, R.M. Laminagraphy in the diagnosis of temporomandibular joint disorders. J Am Dent Assoc, v.46, p.621-648, June 1953.

84. RICKETTS, R.M. Variations of the temporomandibular joint as revelead by cephalometric laminagraphy. Am J Orthod, v.36, n.12, p.877898, Dec. 1950.

85. ROSNER, D.; GOLDBERG, G.F. Condylar retruded contact position and intercuspal position correlation in detulous patients. Part I: tree- 
dimensional analysis of condilar registrations. J Prosthet Dent, v.56, n.2, p.230-237, Aug. 1986.

86. ROTH, R.H. Functional occlusion for the orthodontist. J Clin Orthod, v.15, n.1, p.32-51, Jan. 1981a.

87. ROTH, R.H. Functional occlusion for the orthodontist. J Clin Orthod, v.15, n.3, p.174-198, Mar. 1981b.

88. ROTH, R.H. Gnathological concepts and the orthodontically treated case. Bull Pacif Coast Soc Orthod, v.44, n.2, p.20-22; July 1969.

89. ROTH, R.H. Temporomandibular pain-dysfunction and occlusal relationship. Angle Orthod, v.43, n.2, p.136-153, Apr. 1973.

90. ROTH, R.H.; ROLFS, D.A. Functional occlusion for the orthodontist. J Clin Orthod, v.15, n.2, p.100-123, Jan. 1981.

91. ROURA, N.; CLAYTON, J.A. Pantographic records on temporomandibular joint dysfunction subjects treated with occlusal splints: a progress report. J Prosthet Dent, v.33, n.4, p.442-453, Apr. 1975.

92. SCHUYLER, C.H. Occlusal harmony as a basic requisite in orthodontics. N Y J Dent, v.24, n.11, p.386-388, Nov. 1954. 
93. SCHUYLER, C.H. Principles employed in full denture prosthesis which may be applied in other fields of dentristry. J Am Dent Assoc, v.16, n.11, p.2045-2054, Nov. 1929.

94. SCHWEIKERT, E.O. Centric relation and occlusion in full mouth reconstruction. Quintessence Dent Technol, v.9, n.5, p.313-316, May 1985.

95. SEARS, V.H. Jaw relations and means of recording the most important articular adjustments. Dent Cosmos, v.68, n.11, p.1047-1054, Nov. 1926.

96. SOLGERG, W.; CLARK, G; RUGH, J. Nocturnal electromyographic evaluation of bruxism patients undergoing short term splint therapy. J Oral Rehabil, v.2, n.3, p.215-223, July 1975.

97. STUART, C.E. Articulation of human teeth. Dent Items Interest, v.61, n.11, p.1029-1037, Nov. 1939.

98. THOMPSON, J.R. Function, the neglected phase of orthodontics. Angle Orthod, v.26, n.3, p.129-143, July 1956.

99. TIMM, T.A.; HERREMANS, E.L.; ASH, M.M. Occlusion and orthodontics. Am J Orthod, v.70, n.2, p.138-145, Aug. 1976. 
100. URSI, W.J.S. Determinação da maturidade esquelética através de radiografias carpais: sua importância no tratamento ortodônticoortopédico. In: INTERLANDI, S. Ortodontia: bases para iniciação. 3.ed. São Paulo: Artes Médicas, 1994. Cap.19. p.377-391.

101. UTT, T.W.; MEYERS Jr., C.E.; WIERZBA, T.F.; HONDRUM, S.O. A three-dimensional comparison of condylar position changes between centric relation and centric occlusion using the mandibular position indicator. Am J Orthod Dentofac Orthop, v.107, n.3, p.298-308, Mar. 1995.

102. VALLON, D.; EKBERG, E.; NILNER, M.; KOPP, S. Occlusal adjustment in patients with craniomandibular disorders including headaches. A 3- and 6-month follow-up. Acta Odontol Scand, v. 53, n.1, p. 5559, Feb. 1995.

103. VAN BLARCOM, C.W. Glossary of prosthodontic terms. 6.ed. J Prosthet Dent, v.71, n1, p.41-112, Jan. 1994.

104. WEINBERG, L.A. An evaluation of occusal factors in TMJ dysfunctionpain syndrome. J Prosthet Dent, v.41, n.2, p.198-208, Feb. 1979.

105. WEINBERG, L.A. Optimum temporomandibular joint condyle position in clinical practice. Int J Periodontics Restorative Dent, v.5, n.1, p.10-27, 1985. 
106. WEINBERG, L.A. The role of muscle deconditioning for occlusal corrective procedures. J Prosthet Dent, v.66, n.2, p.250-255, Aug. 1991.

107. WILLIAMSON, E.H. The role of craniomandibular dysfunction in orthodontic diagnosis and treatment planning. Dent Clin North Am, v.27, n.3, p.541-560, July 1983.

108. WOOD, D.P.; ELLIOTT, R.W. Reproducibility of the centric relation bite registration technique. Angle Orthod, v.64, n.3, p.211-220, 1994.

109. WOOD, D.P.; FLOREANI, K.J.; GALIL, K.A.; TETERUCK, W.R. The effect of incisal bite force on condylar seating. Angle Orthod, v.64, n.1, p.53-61, 1994.

110. WOOD, D.P.; KORNE, P.H. Estimated and true hinge axis: a comparison of condylar displacements. Angle Orthod, v.62, n.3, p.167-175, Fall 1992.

111. WOOD, G.N. Centric relation and the treatment position in rehabilitating occlusions: a physiologic approach. Part I: developing an optimum mandibular posture. J Prosthet Dent, v.59, n.6; p. 647-651, June 1988. 


\section{SUMMARY}

\section{CONDYLAR SHIFTING BETWEEN CR AND MIC, WITH AND WITHOUT USE OF BITE-SPLINT, IN SYMPTOM-FREE CLASS II PATIENTS}

Condylar shifting between the mandibular positions of CR and MIC are generally considered frequent in the population. The present investigation has studied condylar shifting in patients with Class II malocclusion with no apparent clinical signs or symptoms of TMD, prior to any orthodontic care. The sample consisted of two groups. The experimental group consisted of 22 individuals, equally distributed in both sexes, presenting an average age of 14years and 8 months. These patients used bite-splints for na average of 7 months and 22 days prior to the making of records. The control consisted of 23 individuals (10 male and 13 females) with an average age of 16 years and 8 months, and they did not use bite-splints. The condylar shiftings of both groups were measured in the three directions of space. Casts were mounted on the articulator. Both articulator and condylar postion Indicator were from Panadent. In the vertical direction, the average condylar shifting for the experimental group was $4.24 \mathrm{~mm}$ in the right side, and $3.86 \mathrm{~mm}$ in the left side. These same shiftings in the horizontal direction were $0.72 \mathrm{~mm}$ in the 
right side, and $-0,51 \mathrm{~mm}$ in the left side. In the transverse direction, average shifting was $0.03 \mathrm{~mm}$. In the vertical direction, the control group showed average condylar shiftings of $1.31 \mathrm{~mm}$ in the right side, and $1.86 \mathrm{~mm}$ in the left side. In the same group, horizontal shifting was $-0.13 \mathrm{~mm}$ in the right side, and $-0.11 \mathrm{~mm}$ in the left side. Transverse shifting was $-0.03 \mathrm{~mm}$. Statistically significant differences between experimental and control groups were found only when right and left condyle shifting data in the vertical direction were compared, the experimental group presenting significantly greater figures. Statistically significant differences were also found between the vertical direction measurements of right and left sides in the experimental group, the right side presenting significantly greater figures. When males were compared to females, no statistically significant differences were observed. In the experimental group, no correlation between splint wearing time and vertical shifting could be observed. Finally, in the experimental group, a significant negative correlation between chronological age and right and left vertical condylar shifting was observed.The same significant negative correlation was observed between skeletal maturity and rigth and left vertical condylar shifting. Thus, for the experimental group, the elder the individual or the greater the skeletal maturity, the lesser is the condylar shifting in the vertical direction. In the present study, it was confirmed that condylar shifting between $\mathrm{CR}$ and $\mathrm{MIC}$ is frequent in Class II patients with no signs and symptoms of TMD. It was also observed that vertical condylar shiftings are more markedly observed with the use of bite-splints, even in asymptomatic patients. 


\section{APÊNDICES}




\section{TERMO DE CONSENTIMENTO ESCLARECIDO}

Nome do paciente:

Nome do responsável:

Eu,

$R G$.

fui informado por este documento que:

1- Qualquer tratamento ortodôntico só pode ser iniciado depois de realizados exames e estabelecido o diagnóstico. Serão então, realizadas moldagens das arcadas, tomadas telerradiografias, radiografias panorâmicas, radiografia carpal, fotografias e slides, ao início, durante e ao final do tratamento ortodôntico. Serão obtidas ainda, tomografias computadorizadas e exames por ressonância magnética.

2- Todos os pacientes a serem tratados na clínica de ortodontia da FOUSP, às segundas-feiras, no período da manhã, passarão por uma fase de diagnóstico, quando deverão usar placa de mordida superior, por período suficiente para relaxar os músculos da face.

3- Antes do início do uso da placa, será realizado um estudo, em que serão utilizadas duas outras formas de relaxar a musculatura. A primeira delas implica no uso de um pequeno botão de acrílico, entre os dentes anteriores, por um período total de 24 horas. Nesta fase, o paciente 
deverá comparecer à Clínica de ortodontia em dois dias consecutivos. Para que não haja risco de engolir o botão de acrílico, este deverá ser amarrado com um pedaço comprido de fio dental, fixado na roupa por meio de uma presilha de fralda, especialmente à noite, para dormir. A segunda forma de relaxar a musculatura envolve a ingestão de uma única dose do medicamento Rivotril. Este será tomado em dia e hora a serem definidos, e na presença da professora responsável pela clínica. Este medicamento envolve risco para os pacientes que apresentem os seguintes problemas de saúde: disfunção renal, hepática ou respiratória crônicas, glaucoma, miastenia e porfiria. Envolvem risco ainda, se associados ao alcool ou a outras drogas depressoras do sistema nervoso central. Portanto, estou ciente de que os pacientes que tenham qualquer das alterações citadas, façam uso regular de alcool ou drogas, ou mulheres grávidas deverão informar a professora responsável e não poderão fazer parte deste estudo.

4- Com o relaxamento da musculatura, decorrente do emprego dos três tipos de relaxadores, os dentes passarão a se tocar de forma diferente e poderão exigir tratamento com aparelho fixo, que envolva extrações de dentes permanentes ou cirurgia ortognática da face. Para serem tratados nesta clínica, todos os pacientes deverão estar cientes desta possibilidade. Independentemente do tipo de tratamento necessário, fica assegurado que este será realizado no Departamento de Ortodontia e Odontopediatria da FOUSP, exclusivamente na clínica que transcorre às segundas-feira, no período da manhã. Durante o tratamento todo, os 
pacientes deverão ter disponibilidade de tempo para comparecer à faculdade, no horário mencionado, a cada uma, duas ou três semanas, dependendo da fase do tratamento.

5- O paciente tem a possibilidade de desistir da pesquisa a qualquer momento. Porém, o tratamento corretivo só será realizado se for cumprido o período total de uso da placa miorrelaxante, necessário para o diagnóstico correto da maloclusão.

Sendo seu responsável, autorizo o menor acima identificado, a participar do estudo mencionado e receber tratamento ortodôntico nas condições expressas neste documento, estando ciente e de acordo com as normas aqui descritas. Também estou de acordo, que toda documentação obtida durante o tratamento ortodôntico permaneça sob guarda do Departamento de Ortodontia e Odontopediatria, autorizando sua irrestrita divulgação.

São Paulo, / / 
nome

- tel res.:

endereço

- tel recados:

1. Há relato de:

A- Ruídos na ATM?

( ) NÃO ( ) ESTALIDO ( ) CREPTAÇÃO

- Quando?

B- Sensação de fadiga dos maxilares?
( ) NÃO
( ) SIM

C- Sensação de rigidez dos maxilares?
( ) NÃO
( ) Ao acordar
( ) Durante movimentos mandibulares

D- Dificuldade de realizar abertura grande da boca?
( ) NÃO
( ) SIM

E- Bloqueio ocasional de curta duração, durante movimento mandibular ( travamento )?
( ) NÃO
( ) SIM

F- Luxação mandibular (deslocamento condilar para fora da fossa mandibular, com fixação naquela posição)?
( ) NÃO
( ) SIM

G- Dor durante os movimentos mandibulares?
( ) NÃO
( ) Às vezes
( ) Constantemente

H- Dor na região da ATM?
( ) NÃO
( ) Às vezes
( ) Constantemente

I- Dor nos músculos da mastigação? 

( ) NÃO
( ) Às vezes
( ) Constantemente

2- Aperta os dentes durante o dia?
( ) SIM
( ) NÃO

3- Já Ihe foi dito que range os dentes ao dormir?
( ) SIM
( ) NÃO

4- Tem dor de cabeça com freqüência?
( ) SIM
( ) NÃO

5- Já teve artrite?

( ) SIM

( ) NÃO

6- Já teve gota?( ) SIM

( ) NÃO

7- Já sofreu golpe forte nos lados da cabeça ou mandíbula?
( ) SIM
( ) NÃO

3- Está sob tratamento médico?

\section{Qual?}

4- Está tomando algum medicamento?

$$
\begin{aligned}
& \text { Qual(is)? } \\
& \begin{array}{ll}
\text { ( ) } \operatorname{SIM} & \text { ( ) NÃO }
\end{array}
\end{aligned}
$$

Afirmo ter respondido corretamente às questões acima.

São Paulo, / / 
Ficha de exame clínico

nome

data do exame

A- Tipo de maloclusão de Angle: ( ) Cl I ( ) Cl II ( ) div. 1a ( ) subdiv.

( ) div. $2 \underline{\mathrm{a}}$ ( ) subdiv.

( ) Cl III ( ) subdiv.

B- Mordida Aberta ( ) NÃO ( ) Anterior ( ) Posterior ( ) direita

( ) esquerda

C- Sobressaliência anterior- ....mm

D- Sobremordida anterior- .....mm ( ) Normal ( ) Profunda

E- Máxima distância entre as bordas incisais- ....mm

F- Máxima abertura da mandíbula- ....mm

G- Extensão da lateralidade máxima-
direita:...mm
( ) com som
( ) sem som
esquerda:....mm ( ) com som
( ) sem som

H- Extensão da protrusão máxima- ....mm （ ) sem desvio

com desvio ( ) D com som ( ) D ( ) E

com desvio ( ) E com som ( ) D ( ) E

I- Abertura e fechamento mandibular:

( ) Trajeto reto

( ) sem sons palpáveis na ATM

( ) com sons palpáveis na ATM

( ) D ( ) E
( ) Trajeto com desvio $>2 \mathrm{~mm}$ para o lado ( ) D ( ) E

( ) sem sons

( ) com sons ( ) D ( ) E

J- Travamento: 
( ) NÃO

( ) Durante abertura e fechamento mandibular

( ) Lateralidade direita ( ) esquerda

( ) Protrusiva

K- Luxação: ( ) NÃO ～（ ) SIM

L- Dor muscular à palpação:

- Masséter profundo

( ) D $\quad$ ( ) E

- Masséter superficial

( ) D ( ) E

- Feixe posterior temporal

( ) D ( ) E

- Feixe anterior temporal

( ) D ( ) E

- Inserção temporal no

$\begin{array}{cll}\text { processo coronóide } & \text { ( ) D } & \text { ( ) E } \\ \text { - Pterigóideo externo } & \text { ( ) D } & \text { ( ) E } \\ \text { - Pterigóideo interno } & \text { ( ) D } & \text { ( ) E }\end{array}$

M- Ciclo mastigatório:

$\begin{array}{lll}\text { Guia anterior: ( ) presente } & \text { ( ) ausente } \\ \text { Guia pelo canino: } & \text { ( ) D } & \text { ( ) E } \\ \text { Função de grupo: } & \text { Parcial D ) } & \text { Parcial E ( ) } \\ & \text { Total D ( ) } & \text { Total E ( ) }\end{array}$

Com contato simultâneo: Lado trab.D: Não trab.E:

Lado trab.E: Não trab.D:

N- Nível de flacidez ligamentar:

O- Facetas de desgaste nos dentes: 76543211234567

76543211234567

OBS 
Autorizo a reprodução pelos interessados.

Solange Mongelli de Fantini

São Paulo, 20 de fevereiro de 2009. 